Columbia Law School

Scholarship Archive

1992

\title{
Apocalypse Next Time?: The Anachronistic Attack on Habeas Corpus/Direct Review Parity
}

James S. Liebman

Columbia Law School, jliebman@law.columbia.edu

Follow this and additional works at: https://scholarship.law.columbia.edu/faculty_scholarship

Part of the Law Commons

\section{Recommended Citation}

James S. Liebman, Apocalypse Next Time?: The Anachronistic Attack on Habeas Corpus/Direct Review Parity, 92 Colum. L. ReV 1997 (1992).

Available at: https://scholarship.law.columbia.edu/faculty_scholarship/117

This Article is brought to you for free and open access by the Faculty Publications at Scholarship Archive. It has been accepted for inclusion in Faculty Scholarship by an authorized administrator of Scholarship Archive. For more information, please contact scholarshiparchive@law.columbia.edu. 


\title{
APOCALYPSE NEXT TIME?: THE ANACHRONISTIC ATTACK ON HABEAS CORPUS/DIRECT REVIEW PARITY
}

\author{
James S. Liebman*

\section{Table of Contents}

I. Parity and Disparity: A Comparison of Two Modes of Federal Court Review of State Court Determinations of Federal Law ............................ 1999

II. Wrong and Wright: The Opposing Views of Justice THOMAS AND Justices O'ConNor and KENNEdy .........2010

A. The Questions Presented and Prescribed ...............2010

B. A Critical Analysis of Justice Thomas' Arguments Against De Novo Habeas Corpus Review ....................... 2012

C. Victory on Points: $A$ Less Critical Analysis of the O'Connor and Kennedy Opinions ........................... 2033

D. Is to Ought: The Search for an Affirmative Case..........2036

III. Two Theses and Two Tests of the Historical Scope of Habeas Corpus Review in the United States .......... 2041

A. Two Theses ................................204I

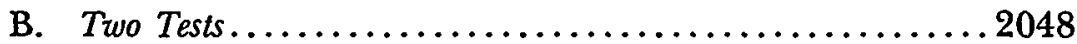

IV. A New History of Habeas Corpus in Statutory and Federal JuRisdictional Context...................2055

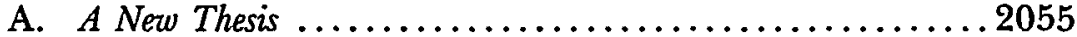

B. Federal Question Writs of Error and Habeas Corpus Review Under the 1789 Judiciary Act ......................2057

C. The Antebellum Removal and Habeas Corpus Acts ......... 2062

D. The Reconstruction Era Accretions to the Federal Courts' Writ of Error, Removal, and Habeas Corpus Jurisdiction ........ 2063

E. Post-Reconstruction Limitations on Removal and Habeas

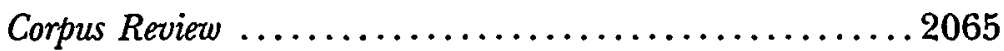

F. Late Nineteenth Century and Early Twentieth Century Revisions of the Supreme Court's Writ of Error Jurisdiction ... 2072

G. Moore to Brown: Criminal Procedure Revolution and Direct Review Devolution ...........................2081

H. The Brown "Revolution": The Impact of Certiorarification Realized.............................. 2083

I. Congressional Affirmation: The 1966 Amendments ........2084

J. Summary .............................. 2091

V. Conclusion: The Wright Stuff Versus the Right Stuff 2094

* Professor of Law, Columbia University. Dedication, of course, goes to Henry, who came to Janet and me about the same time this Article did. 
Today, a district court's habeas corpus review of the constitutionality of a state criminal conviction and the Supreme Court's direct review of the same question are nearly identical. Last Term, in Wright $v$. West ${ }^{1}$ an otherwise mundane criminal procedure case, the Supreme Court rewrote the question presented to ask whether the parity between federal habeas corpus and direct appellate review should be destroyed. The Court proposed abandoning in habeas corpus an important trait shared by the two modes of review-de novo consideration of legal and mixed legal-factual questions. ${ }^{2}$

To those who value meaningful habeas corpus review, ${ }^{3}$ the Court's order augured Apocalypse Now. The seeming momentousness of the Court's action was enhanced by its timing. Just three weeks before, the Senate had come within a few votes of ending a Republican filibuster and passing a habeas corpus reform bill, previously adopted by the House, that rejected a Bush Administration proposal to replace de novo review with deferential review of state court determinations of law. ${ }^{4}$ The Court's sua sponte order requesting briefing on a question presented by neither the parties nor the case thus arrogated to the Court an issue that the political branches otherwise might have, but have not since, settled.

Despite ominous signals from the Court that pervasive change was afoot, the Court unanimously dispatched Wright on the mundane criminal procedure issue initially presented by the parties. But the views expressed in Justice Thomas' plurality opinion (joined by Chief Justice Rehnquist and Justice Scalia) and the Court's nearly simultaneous grants of certiorari in two cases raising similar issues may well portend Apocalypse Next Time. ${ }^{5}$ That Justice O'Connor (joined by Justices Blackmun and Stevens) responded to Justice Thomas' singular brief in support of deferential review with a point-by-point refutation-supported on one of those points by Justice Kennedy's separate opiniononly enhances the sense that battle lines are forming for an impending habeas corpus Armageddon. It is against that possibility that this Article is deployed.

1. 112 S. Ct. 2482 (1992).

2. See Wright v. West, 112 S. Ct. 672 (1991) (mem.) (granting cert. to review West v. Wright, 931 F.2d 262 (4th Cir. 1991)).

3. Myself included. I was co-counsel on the Brief Amici Curiae of Benjamin R. Civiletti, Nicholas deB. Katzenbach, Edward H. Levi, and Elliot L. Richardson, in Support of the Respondent, Wright v. West, 112 S. Ct. 2482 (1992) (No. 91-542) [hereinafter Civiletti Amicus Brief].

4. See Brief Amicus Curiae of Joseph Biden \& Don Edwards at 14-16, Wright v. West, 112 S. Ct. 2482 (1992) (No. 91-542) [hereinafter Biden/Edwards Amicus Brief] (describing these events).

5. See Brecht v. Abrahamson, 112 S. Ct. 2937 (1992) (mem.) (No. 91-7358) (granting certiorari to review 944 F.2d 1363 (7th Cir. 1991)); Withrow v. Williams, 112 S. Ct. 1664 (1992) (mem.) (No. 91-1030) (granting certiorari to review Williams v. Withrow, 944 F.2d 284 (6th Cir. 1991)). 
Part 1 demonstrates the existing parity between habeas corpus review in the district courts and direct review in the Supreme Court. Part II analyzes the opinions in Wright, revealing among other things that a proper determination of the Great Writ's future requires an accurate understanding of its past. In response to that discovery, Part 1 II analyzes Professor Bator's flawed tour de force of $1963,{ }^{6}$ which has greatly influenced but also greatly distorted most contemporary views of the writ's history. Part IV offers a new habeas corpus chronology. My conclusions are twofold. First, although Justices O'Connor and Kennedy, taking the negative side, win the debate on Justice Thomas' proposal in Wright to slash habeas corpus review, their failure to offer an affirmative case leaves the writ vulnerable. Second, a new, more rounded and accurate, history of the writ provides the affirmative case for a habeas corpus/direct appeal parity that extends to de novo review of legal and mixed legal-factual questions.

\section{Parity and Disparity: A Comparison of Two Modes of Federal Court Review of State Court Determinations of Federal Law}

The police arrest Smith for armed robbery. After reading him his Miranda rights and securing his permission to ask questions, two groups of officers, each relieved by the other at intervals, interrogate Smith for ten nighttime and early morning hours. Smith's requests for water and coffee are honored; those for cigarettes, sleep, and a chance to call a friend are not. The interrogation takes place entirely in words; rubber hoses and bright lights are not in evidence. For hours, Smith insists that he had no part in the robbery under investigation. At length, the officers reveal their belief, supported by unspecified evidence, that Smith and Jones previously have committed several other armed robberies and that things will go hard for both Smith and Jones in all the cases if Smith does not cooperate in the case at hand. At Smith's suggestion, the officers promise to suspend proceedings against Smith and Jones on the other robberies if Smith confesses to the robbery at hand. Smith confesses.

After holding an evidentiary hearing on Smith's motion to suppress, the trial court finds the facts set out above and concludes that, promises notwithstanding, the confession was voluntary and admissible. Smith's subsequent conviction rests on the confession. The state supreme court affirms, ruling that a promise not to prosecute the defendant and an associate for other crimes does not taint an otherwise voluntary confession.

Smith asks the United States Supreme Court for a writ of certiorari to review the state supreme court decision, alleging, as the certiorari 
statute requires, (i) that he has been deprived of a "right ... under the constitution, treaties or statutes of . . the United States"7 and (ii) that he has exhausted his state remedies with regard to the federal claim in the sense that he is asking the Court to review a "judgment[] . . rendered by the highest court of a State in which a decision [on the claim] could be had" as of right. ${ }^{8}$ At any other time, the Supreme Court would deny certiorari for lack of an important federal question. ${ }^{9}$ As it happens, Smith's case is the first to reach the Court after a United States Court of Appeals for the Ninth Circuit ruling that police promises not to prosecute the defendant and an associate for other crimes if the defendant confesses to the crime under investigation render the confession involuntary. Notified of the conflict, the Supreme Court grants certiorari to resolve it and-by the way-to review the constitutionality of Smith's conviction.

The type and scope of review Smith can expect from the Supreme Court on direct review are no mystery. Should the Court's analysis of the case turn on legal questions-for example, whether the Fifth and Fourteenth Amendments' voluntariness requirement for admitting custodial confessions can be satisfied by a statement induced by promises not to prosecute other crimes-the Court's review will proceed de novo. ${ }^{10}$ The Court will rely primarily on its existing constitutional precedents, consistent with the degree of freedom to deviate from those precedents that it exercises under the applicable prudential doctrines, most notably stare decisis. ${ }^{11}$ Just as the Court may draw upon other federal and state court opinions and the academic commentary, it also undoubtedly will pay such attention to the state courts' opinions in Smith's very case as their research, reasoning, and rhetoric and the respect due their authors and joiners inspire.

If the Court accepts the long-established "voluntariness" standard, and concludes that promises of nonprosecution do not necessarily violate it, the Court also will review de novo the application of that (or any other) mixed legal and factual standard to the historical facts of the case as found by the state courts. ${ }^{12}$ If the Court's analysis of voluntariness

\section{28 U.S.C. \& 1257(a) (1988).} 1986).

8. Id.; accord Robert L. Stern et al., Supreme Court Practice $\S \S 3.14-3.18$ (6th ed.

9. See generally Stern et al., supra note $8, \S \S 4.1-4.17$ (discussing bases for granting certiorari).

10. See, e.g., Arizona v. Fulminante, 111 S. Ct. 1246, 1252 (1991).

11. See, e.g., Payne v. Tennessee, 111 S. Ct. 2597, 2609-11 (1991).

12. See, e.g., Arizona v. Fulminante, 111 S. Ct. at 1252; Norris v. Alabama, 294 U.S. 587, 589-90 (1935). See generally Stern et al., supra note 8 , $\$ 3.29$, at 186-87 (collecting cases). Along a continuum running from pure questions of fact that have little or no norm content (e.g., whether Smith uttered the words "I pulled that job"), to pure questions of law that are suffused with legal norms (e.g., whether individuals have a right to refuse to answer questions during custodial interrogation), are many questions-sometimes called "law-application" questions-with intermediate levels of norm content (e.g., whether Smith was in "custody" undergoing "interrogation" at 
turns on an historical fact-for example, whether the police had sufficient evidence to proceed with investigations or prosecutions of the other robberies - the Court generally will defer to the state courts' findings with regard to that fact. ${ }^{13}$ Exceptions to this deferential rule arise when there is no finding, ${ }^{14}$ the finding is inadequate (for example, because there is no or too little evidence to support it ${ }^{15}$ ), or the finding is dependent on a legal question in the case (for example, the finding was made in the process of applying an improper legal standard ${ }^{16}$ or was

various junctures). See Monaghan, Constitutional Fact Review, 85 Colum. L. Rev. 229, 235-38 (1985). A well-established Supreme Court jurisprudence segments this continuum into two categories, on which I draw here. In addition to purely factual issues, the Court's "factual question" category includes partially norm-laden lawapplication questions as to which the norms already are fully elaborated or are incapable of further elaboration. See, e.g., Mu'Min v. Virginia, 111 S. Ct. 1899, 1907 (1991) (whether juror is biased is matter of fact); Dayton Bd. of Educ. v. Brinkman, 443 U.S. 526, 534 (1979) (whether school board intentionally maintained segregated school system is matter of fact). In addition to purely legal issues (requiring that norms be identified, and not simply elaborated), the Court's "legal question" category includes so-called "mixed questions of fact and law," i.e., law-application questions involving norms that require additional elaboration or that can only be elaborated by addressing multiple examples. See, e.g., Yates v. Evatt, 111 S. Ct. 1884, 1893-94 (I991) (existence of harmless error treated as question of law); Jackson v. Virginia, 443 U.S. 307, 318-19 (1979) (whether rational juror could find defendant guilty beyond a reasonable doubt is question of law). Although the Court has the power to review all law-application (as well as purely legal) questions de novo, see Monaghan, supra at 263-76, its categorization of some law-application questions as matters of "fact" and not "mixed questions" has the effect of forgoing independent review, apparently based on the difficulty or undesirability of additional judicial norm elaboration.

13. See, e.g., Arizona v. Fulminante, 111 S. Ct. at 1252; Beck v. Ohio, 379 U.S. 89, 100-01 (1964) (Harlan, J., dissenting); Watts v. Indiana, 338 U.S. 49, 50-52 (1949) (plurality opinion); Haley v. Ohio, 332 U.S. 596, 597-98 (1948); Lisenba v. California, 314 U.S. 219, 238 (1941); supra note 12. See generally Stern et al., supra note 8, § 3.29, at 185 (citing cases).

14. See, e.g., Beck v. Ohio, 379 U.S. at 92-93; Ashcraft v. Tennessee, 322 U.S. 143, 147-48 (1944); Carlson v. Washington ex rel. Curtis, 234 U.S. 103, 106 (1914); Reynolds Robertson \& Francis R. Kirkham, Jurisdiction of the Supreme Court of the United States § 112 (Richard F. Wolfson \& Philip B. Kurland eds., 2d ed. 1951) ("A state court cannot, by omitting to pass upon evidence or to make findings of fact, deprive a litigant of the benefit of a federal right ....").

15. See, e.g., Vachon v. New Hampshire, 414 U.S. 478, 480 (1974) (per curiam); Cox v. Louisiana, 379 U.S. 536, 545-49 (1965); Lisenba v. California, 314 U.S. at 238 ("[W]e accept the determination of the triers of fact, unless it is so lacking in support in the evidence that to give it effect would work that fundamental unfairness which is at war with due process."); Stern et al., supra note $8, \S 3.29$, at 185 . A version of this rule is codified in Fed. R. Civ. P. 52(a), which requires federal appellate courts to accept the factfindings of lower federal courts in civil cases except upon a conclusion that those findings are "clearly erroneous." The better view seems to be that the Supreme Court has given, and ought to give, the same treatment to state and lower federal court factfindings. See Alfred Hill, The Inadequate State Ground, 65 Colum. L. Rev. 943, 946-47 (1965).

16. See, e.g., Haynes v. Washington, 373 U.S. 503, 516-18 (1963); Rogers v. Richmond, 365 U.S. 534, 547 (1961) ("Historical facts 'found' in the perspective framed by an erroneous legal standard cannot plausibly be expected to furnish the basis for 
based on evidence that is inadmissible as a matter of federal law $\left.{ }^{17}\right) .^{18}$

When one of these exceptional circumstances is present, the Court has several options. If the existing record permits and the Court is so inclined, it may make its own finding in service of a final resolution of the case. ${ }^{19}$ If the Court is not so inclined, it may-and, if the record, through no fault of the petitioner, is too incomplete to permit such a finding, it must-remand the case so that (generally) the next nearest court in the appellate chain with the capacity to find the facts may do so, and then resolve the remaining legal and mixed legal-factual issues on that basis. ${ }^{20}$ If the record is incomplete for reasons that are the petitioner's fault (for example, he failed to present all the evidence he had,

correct conclusions if and merely because a correct standard is later applied to them."); Lisenba v. California, 314 U.S. at 236; see also Thornburg v. Gingles, 478 U.S. 30, 79 (1986) (civil procedure "Rule 52(a) 'does not inhibit an appellate court's power to correct ... . a finding of fact ... predicated on a misunderstanding of the governing rule of law,' " quoting Bose Corp. v. Consumer Union of United States, Inc., 466 U.S. 485, 501 (1984)).

17. See, e.g., Graham v. Gill, 223 U.S. 643, 644-45 (1912) (mem.); Dower v. Richards, 151 U.S. 658, 667 (1894).

18. My "adequate and independent factfinding" terminology intentionally mimics the analogous, but more familiar, "adequate and independent state grounds" doctrine. The two doctrines are distinct, however. Unlike the "adequate and independent state ground doctrine," the "adequate and independent factual ground" doctrine applies to both state and federal court determinations, see supra note 15 , and is dictated by statute on the basis of prudential concerns (e.g., the comparative advantage of the prior state courts as factfinders, see infra note 48 ) rather than by constitutional limitations on federal court jurisdiction. Compare Fay v. Noia, 372 U.S. 391, 463-70 (1963) (Harlan, $\mathrm{J}$., dissenting) (discussing the constitutional-jurisdictional nature of the adequate and independent state grounds doctrine), questioned on other grounds in Wainwright $v$. Sykes, 433 U.S. 72, 87-88 (1977), and overruled on other grounds by Coleman v. Thompson, 111 S. Ct. 2546, 2565 (1991) with Stein v. New York, 346 U.S. 156, 181 (1953) (Court is not "completely bound by state court determination of any issue essential to decision of a claim of federal right, else federal law could be frustrated by distorted fact finding."); Republican River Bridge Co. v. Kansas Pac. Ry., 92 U.S. 315, 317 (1875) ("[T] his court can review the decision of [a state] court on both the law and the fact, so far as may be necessary to determine the validity of the right set up under the act of Congress ...."). Linking the established "adequate and independent state grounds" doctrine to what I here call the "adequate and independent factfinding" principle are Dower v. Richards, 151 U.S. at 667 , and Quimby v. Boyd, 128 U.S. 488, 489 (1888) (writ of error must be dismissed when the "alleged errors involved questions either of fact, or of state and not of Federal law").

19. See, e.g., Beck v. Ohio, 379 U.S. 89, 92-93 (1964); Ashcraft v. Tennessee, 322 U.S. 143, 145 (1944) (undertaking own factual analysis because "[t]he record discloses that neither the trial court nor the Tennessee Supreme Court actually held as a matter of fact that petitioners' confessions were 'freely and voluntarily made' "); Brooklyn Sav. Bank v. O'Neil, 324 U.S. 697, 703 (1945); Carlson v. Washington ex rel. Curtiss, 234 U.S. 103, 106 (1914).

20. See, e.g., Stern et al., supra note $8, \$ 3.29$, at 187 ("Court may leave open the factual issue, allowing state court to make the necessary findings on remand following reversal for error of law."); see also United States Postal Serv. Bd. of Governors v. Aikens, 460 U.S. 711,717 (1983) (remanding because original factfinding may have been influenced by erroneous view of law). 
contrary to state procedural rules), and if the state courts forbore further inquiry because of that default (for example, those courts noted the existence of a legal issue not resolvable on the facts before them, but did not address it because the defendant waived the inquiry), the Court must deny relief because of that state procedural ground, assuming the Court finds it to be both "adequate" and "independent of federal law."21

Vary the scenario in one minor respect. The Ninth Circuit decision is deferred for two months, so that counsel for Smith has no directly conflicting decision to cite in his certiorari petition. The Court denies certiorari, leaving Smith to his habeas corpus remedies. ${ }^{22}$ Smith accordingly asks a federal district court for a writ of habeas corpus to review the legality of his state court conviction, alleging, as the habeas corpus statute requires, (i) that he "is in custody in violation of the Constitution or laws or treaties of the United States," 23 and (ii) that he has exhausted his state remedies with regard to the federal claim. ${ }^{24}$

As of this moment, at least, the type and scope of review that Smith can expect from a federal district court ${ }^{25}$ on habeas corpus are no mystery either. Should the federal court's analysis of the case turn on legal questions, its review will proceed de novo. ${ }^{26}$ The federal court will rely primarily on the Supreme Court's constitutional precedents, as well as its own and those of the appropriate circuit court of appeals, consistent with the degree of freedom to deviate from those precedents that the court may exercise under the applicable prudential doctrines, most no-

21. See, e.g., James v. Kentucky, 466 U.S. 341, 348-52 (1984); Michigan v. Long, 463 U.S. 1032, 1037-44 (1983); Hathorn v. Lovorn, 457 U.S. 255, 262-63 (1982).

22. The Court and its individual members often combine denials of certiorari with reminders of the availability of habeas corpus as an alternative. See, e.g., Spencer v. Georgia, 111 S. Ct. 2276, 2276 (1991) (mem.) (Kennedy, J., concurring in the denial of certiorari) ("This case appears to present important questions of federal law, and if I thought our [case law] . . . would prevent us from reaching those issues on federal habeas review, I would have voted to grant certiorari."); Irvin v. Indiana, 353 U.S. 948, 948 (1957) (per curiam) (denying certiorari "without prejudice to filing for federal habeas corpus after exhausting state remedies").

23. 28 U.S.C. $\$ \S 2241$ (c)(3), 2254(a) (1988).

24. See id. § 2254(a)-(b). See generally 1 James S. Liebman, Federal Habeas Corpus Practice and Procedure $\S 5.3 \mathrm{~b}$ (1988) (discussing habeas corpus exhaustion requirements under the $A c t)$.

25. Smith initially must file his petition in a federal district court. See 28 U.S.C. $\S 2242$ (1988); Fed. R. App. P. 22(a); S. Ct. R. 20.4(a); Dixon v. Thompson, 429 U.S. 1080, 1080-81 (1977). An appeal to the appropriate United States Court of Appeals thereafter is available if the state appeals the district court's grant of the writ or, upon the issuance of a "certificate of probable cause" to appeal by the district court or court of appeals, if the petitioner appeals the district court's denial of the writ. See 28 U.S.C. $\S 2253$ (1988). The Supreme Court may review the court of appeals' decision on certiorari. See 2 Liebman, supra note 24, $\$$ 32.1-35.2.

26. See, e.g., Kimmelman v. Morrison, 477 U.S. 365, 373-83 (1986); Miller v. Fenton, 474 U.S. 104, 112-13, 115 (1985); Townsend v. Sain, 372 U.S. 293, 318 (1963). 
tably the nonretroactivity principle. ${ }^{27}$ Just as the federal court may draw upon the opinions of other federal circuit and district courts, other state courts, and academics, it also undoubtedly will pay such attention to the state courts' opinions in Smith's case as those opinions inspire on their merits and on the strength of their authors' and joiners' reputations.

If the federal court accepts the long-established "voluntariness" standard (as, no doubt, it willi28), and concludes that promises of nonprosecution do not necessarily violate it, the court also will review de novo the application of that mixed legal and factual standard to the historical facts of the case. ${ }^{29}$ If the federal court's analysis turns on an historical fact, the federal court in most cases will defer to the state courts' findings with regard to that fact. ${ }^{30}$ Exceptions to this rule arise when there is no finding, ${ }^{31}$ the finding is inadequate (for example, because there is no or little evidence to support $\mathrm{it}^{32}$ or because the factfinding procedure was unfair ${ }^{33}$ ), or the finding is dependent on a legal question in the case (for example, the finding was made in the process of applying an improper legal standard ${ }^{34}$ ).

When one of these exceptional circumstances is present, the federal court has several options. If the existing record permits, the court

27. See, e.g., Stringer v. Black, 112 S. Ct. 1130, 1135 (1992); Teague v. Lane, 489 U.S. 288, 305-07 (1989) (plurality opinion); infra notes 42-43, 581-585 and accompanying text.

28. Recently, the Supreme Court unanimously reaffirmed that standard in Arizona v. Fulminante, 111 S. Ct. 1246, 1252 (1991); id. at 1261 (Rehnquist, J., dissenting); and, in a habeas corpus context, in Miller v. Fenton, 474 U.S. at 112.

29. See, e.g., Miller v. Fenton, 474 U.S. at 112, 113-14; Townsend v. Sain, 372 U.S. at 318; Thomas v. Arizona, 356 U.S. 390, 393 (1958); Brown v. Allen, 344 U.S. 443, 507 (1953) (Frankfurter, J.); supra note 12; infra notes 161-178 and accompanying text.

30. An adequate state court factfinding is presumed correct absent a showing "by convincing evidence" that it is erroneous. 28 U.S.C. $\$ 2254$ (d) (1988); see, e.g., Burden v. Zant, 111 S. Ct. 862, 864 (1991) (per curiam); Parker v. Dugger, 111 S. Ct. 731, 739 (1991); Sumner v. Mata, 449 U.S. 539, 550 (1981); Townsend v. Sain, 372 U.S. at 318.

31. See, e.g., 28 U.S.C. § 2254(d) (1988); Ford v. Wainwright, 477 U.S. 399, 410-11 (1986) (plurality opinion); Townsend v. Sain, 372 U.S. at 314, 320; 1 Liebman, supra note $24, \S 20.3 \mathrm{c} \&$ n.16.

32. See, e.g., 28 U.S.C. $\S \S 2254$ (d)(8), 2254(d) (1988) (no deference due state court factfindings "not fairly supported by the record" or shown "by convincing evidence" to be "erroneous"); Parker v. Dugger, 111 S. Ct. at 739; Cabana v. Bullock, 474 U.S. 376, 389-90 (1986); Townsend v. Sain, 372 U.S. at 316; see also 1 Liebman, supra note 24, \& 28.1, at 440-41 \& nn.15-17 (analogizing \$2254(d)'s "convincing evidence" standard to the "clearly erroneous" standard in Fed. R. Civ. P. 52(a)).

33. State court factindings are presumed correct only if made using a "full [and] fair" procedure. 28 U.S.C. $\$ 2254$ (d)(6) (1988); accord Keeney v. Tamayo-Reyes, 112 S. Ct. 1715, 1720 (1992); id. at 1723 (O'Connor, J., dissenting); Ford v. Wainwright, 477 U.S. at 410-11, 416-18; id. at 427 (Powell, J., concurring); id. at 430-31 (O'Connor, J., concurring); Blackledge v. Allison, 431 U.S. 63, 74-75, 78 (1977).

34. See, e.g., Townsend v. Sain, 372 U.S. at 315 n.10. 
must make its own findings in service of a final resolution of the case. ${ }^{35}$ If, through no fault of the petitioner, the record is too incomplete to permit such findings, the court then must relegate to the next nearest responsible tribunal with the capacity to find the facts-itself, or more often, a federal magistrate-the task of doing so and then of resolving the remaining legal and mixed legal-factual issues on that basis. ${ }^{36}$ If the record is incomplete for reasons that are the fault of the petitioner, and if the state court did not inquire further because of that default, the federal courts must deny relief because of that state procedural ground, assuming the ground is both adequate and independent of federal law. ${ }^{37}$

Albeit perhaps tedious, the foregoing comparison should demonstrate the near parity between the review of claims of unconstitutional incarceration secured by the few state prisoners whose certiorari petitions to the Supreme Court are granted on direct review and by the many state prisoners whose petitions are reviewed by federal district courts on habeas corpus. ${ }^{38}$ To be sure, the two modes of review are not identical. But identical principles applied to courts with different practical capacities explain the, in any event, rather modest differences.

First, unlike the federal district courts, whose jurisdiction is mandatory, the Supreme Court only reviews constitutional issues arising in state criminal cases that it chooses to review. The Court's special statutory capacity to determine its own docket is, in fact, the product of two special incapacities-that of the Court to review the number of cases it would face were review available as of right, and that of any "Highest Court in the Land" to fulfill its peculiar unifying and concluding duties with more members than is consistent with efficient en banc proceedings. Because these latter incapacities do not affect the numerically more elastic lower federal courts, those courts may more easily be granted jurisdiction (on application by the aggrieved party) over all constitutional issues arising in state criminal courts. Indeed, inside and outside the habeas corpus context, it is precisely the right to lower fed-

35. See, e.g., Parker v. Dugger, 111 S. Ct. at 737, 739; Townsend v. Sain, 373 U.S. at 310-12; Tague v. Puckett, 874 F.2d 1013, 1015 (5th Cir. 1989).

36. See, e.g., Hull v. Freeman, 932 F.2d 159, 170 n.9 (3d Cir. 1991) ("[1]f an evidentiary hearing is necessary in a federal habeas case to resolve a disputed factual question, it should be held in federal district court, rather than state court."); Smart v. Scully, 787 F.2d 816, 821 (2d Cir. 1986); Grigsby v. Mabry, 637 F.2d 525, 528-29 (8th Cir. 1980); J. Skelly Wright \& Abraham D. Sofaer, Federal Habeas Corpus for State Prisoners: The Allocation of Fact-Finding Responsibility, 75 Yale L.J. 895, 906-19 (1966).

37. See, e.g., Keeney v. Tamayo-Reyes, 112 S. Ct. at 1717-19, 1720 n.5; Coleman v. Thompson, 111 S. Ct. 2546, 2554-55 (1991); Harris v. Reed, 489 U.S. 255, 263-64 (1989); 1 Liebman, supra note 24, § 24.1 \& nn.18-26 (Supp. 1992).

38. See, e.g., Paul M. Bator et al., Hart and Wechsler's The Federal Courts and The Federal System 1486 (2d ed. 1973) (it is "impossible" to draw a "logical distinction in kind between direct review and review on habeas corpus") (hereinafter Hart \& Wechsler, 2d ed.]. 
eral court review of even mundane federal questions that has been understood to justify limiting the Supreme Court's docket to the tiny minority of especially important federal questions that warrant a discretionary grant of certiorari. ${ }^{39}$

In a federal system that for the most part disperses the responsibility to adjudicate questions of national law among a massive collection of generalist state judiciaries, it makes sense for Congress to allocate to the relatively small and expert lower national judiciary the unifying and concluding function with respect to those legal questions that the Highest Court ideally should, but in practice cannot manage to, review itself. ${ }^{40}$ And were it then found that, even thus dispersed, the unifying and concluding function outstripped the capacities of the federal judiciary as a whole, it still might make sense to ration the federal judiciary's performance of that function by concentrating it on cases of particular national interest. Given the constitutional nature of the federal questions arising in criminal cases, and the important libertarian interests jeopardized by those questions' adverse adjudication, it makes further sense to use the jurisdictional prerequisite of "custody," as does the habeas corpus statute, as a proxy for the nationally important questions whose prior resolution has in fact jeopardized nationally important interests. 41

Second, the lower federal judiciary on habeas corpus has less free-

39. See, e.g., Rose v. Mitchell, 443 U.S. 545, 561 (1979); Darr v. Burford, 339 U.S. 200, 229 (1950) (Frankfurter, J., dissenting) (in the absence of federal habeas corpus review, "[t]he burden of the Court's volume of business will be greatly increased, not merely because a greater number of certiorari petitions would be filed, but by reason of the effective pressure toward granting petitions more freely. For . . . it would require that every doubt be resolved in favor of granting certiorari, rather than leaving the case to the District Courts"), overruled on other grounds by Fay v. Noia, 372 U.S. 391 (1963); Patrick E. Higginbotham, Reflections on Reform of $\S 2254$ Habeas Petitions, 18 Hofstra L. Rev. 1005, 1009-10 (1990); Paul J. Mishkin, The Federal "Question" in the District Courts, 53 Colum. L. Rev. 157, 158 \& n.11 (1953) ("'T] he exercise of federal question jurisdiction by lower federal tribunals presumably permits the Supreme Court to confine itself ... to the solving of new problems rather than the policing of old solutions, without the loss that might otherwise be entailed in the effectuation of national rights.").

40. See Martin v. Hunter's Lessee, 14 U.S. (1 Wheat.) 304, 336-39 (1816).

41. See 28 U.S.C. $\S \S 2241$ (c), 2254(a) (1988). Put differently, what is hypothesized here and at later stages of my argument, see infra notes 212-217, 329-331 and accompanying text, is a congressional policy favoring federal review as of right of claims that simultaneously protect two kinds of liberty interests. First is an interest in not being convicted and confined in violation of national law. Second is an interest in the enforcement of national laws tbat are particularly "important" or "fundamental" because they limit government interference through means other than conviction and confinement with the moving party's liberty. For example, overturning a conviction imposed under a law that violates the prisoner's First Amendment free expression rights, or obtained through a procedure that violates her Fifth Amendment privilege against self-incrimination, preserves her liberty interests not only in immunity from federally unlawful conviction and incarceration but also in free expression, or in protection from physical or psychological coercion. 
dom than the Supreme Court on direct review to deviate from existing Supreme Court precedent. Formally, this discrepancy arises because a "nonretroactivity" bar prevents habeas corpus petitioners from obtaining relief on the basis of new law declared after the conclusion of direct review proceedings in their cases. ${ }^{42}$ In substance, however, the nonretroactivity bar actually preserves parity between direct and habeas corpus review. By cutting off access to legal developments after the date on which the prisoner's direct appeal certiorari petition was denied, ${ }^{43}$ the nonretroactivity doctrine simply limits the prisoner's habeas corpus proceedings to the minimum level of review that she would have received from the Supreme Court on direct review had it granted certiorari. All the nonretroactivity doctrine does, therefore, is to assure that the fortuitous delay in federal review occasioned by a denial of certiorari gives the prisoner no more review on habeas corpus than she would have received on direct review, without giving her any less - thus maintaining direct review/habeas corpus parity.

Although the nonretroactivity doctrine assures parity from the perspective of individual prisoners, disparity still exists from the perspective of the courts involved. On direct review, only stare decisis constrains Supreme Court law making; on habeas corpus review, the nonretroactivity doctrine does as well. Again, this disparity arises from the different institutional capacities of "supreme" and "inferior" courts. The nonretroactivity doctrine simply maintains a proper division of labor by diverting the lower federal courts from law-making to law-applying tasks, in order to take best advantage of the High Court's law-making capacities and avoid interfering with the High Court's law-unifying capacities. ${ }^{44}$

Finally, in the tiny and shrinking proportion of cases that turn on unresolved factual issues requiring evidentiary procedures as opposed to mere factfinding, ${ }^{45}$ the powers that federal district courts exercise on habeas corpus differ from those available to the Supreme Court on direct appeal. On direct review, the Supreme Court must remand to some other court to take evidence; on habeas corpus review, the federal

42. See authority cited supra note 27 ; infra notes $581-585$ and accompanying text.

43. See, e.g., Sawyer v. Smith, 497 U.S. 227, 237 (1990); Saffle v. Parks, 494 U.S. 484, 488-89 (1990).

44. See Teague v. Lane, 489 U.S. 288, 315-16 (1989) (plurality opinion). Elsewhere, I have discussed contrary policies that favor a law-making role for the lower judiciary on habeas corpus. See James S. Liebman, More Than "Slightly Retro": The Rehnquist Court's Rout of Habeas Corpus Jurisdiction in Teague v. Lane, 18 N.Y.U. Rev. L. \& Soc. Change 537, 564-77 (1990-91) [hereinafter Liebman, More Than "Slightly Retro"]. But the existence of those competing policies does not undermine the point being made here - that the current scope of habeas corpus can be explained as an effort to use the lower federal judiciary as surrogates for the Court's law-applying functions.

45. See Report of the Subcommittee on the Role of the Federal Courts (Richard A. Posner, Chair), in 1 Federal Courts Study Committee, Working Papers and Subcommittee Reports 468-515 (July 1, 1990) (district courts hold hearings in only $1.17 \%$ of all habeas corpus cases). 
district courts must hear the evidence themselves (or, more usually, assign a magistrate to hear it). This is not a discrepancy between direct review and habeas corpus, however, but one between courts with only appellate capacities and those that also have original (evidence-taking) capacities. ${ }^{46}$ Whether on direct or habeas corpus review, the Supreme Court must remand questions requiring evidentiary proceedings, as must the federal courts of appeal on habeas corpus. ${ }^{47}$

That the Supreme Court on direct appeal remands the evidencetaking duties to state evidence-taking courts, while the Supreme Court and federal courts of appeals on habeas corpus remand those duties to federal evidence-taking courts may appear to be another discrepancy. In both cases, however the governing principle is the same: the universal interest in expeditious resolution mandates that the court with evidence-taking capacities highest in the chain of courts that have exercised responsibility over the case resolve all outstanding issues. ${ }^{48}$

46. Calling habeas corpus an appellate procedure is controversial, although, as I develop below, both descriptively and historically accurate. See infra note 349 and accompanying text. Here, however, I am making a point that is not controversial: given their obligations in, for example, social security cases, federal district judges exercise significant appellate, as well as original, jurisdiction. See, e.g., 42 U.S.C. $\$ 405(\mathrm{~g})$ (I988). As for the constitutional propriety of giving the inferior federal courts "[e]very variety and form of appellate jurisdiction within the sphere of the [constitutional] power [over federal questions], extending as well to [review of] the courts of the States as to those of the nation," with "no distinction . . . between civil and criminal causes," see The Mayor v. Cooper, 73 U.S. (6 Wall.) 247, 252-53 (I867); Martin v. Hunter's Lessee, I4 U.S. (1 Wheat.) 304, 338 (I8I6). The Rooker-Feldman doctrine is not to the contrary. See District of Columbia Court of Appeals v. Feldman, 460 U.S. $462-79$ (1983); Rooker v. Fidelity Trust Co., 263 U.S. 413, 416 (1923). That doctrine does not hold that "[ $t$ ]he jurisdiction possessed by the District Courts [must be] strictly original," hence that the lower federal courts may never hear appeals from state courts in the guise of adjudicating collateral attacks on state court judgments. Rooker v. Fidelity Trust Co., 263 U.S. at 416. Rather, the doctrine simply forbids federal district court appellate review of state court judgments in the gnise of collateral attacks when no federal statute authorizes such review, see District of Columbia Court of Appeals v. Feldman, 460 U.S. at 476, 482; Rooker v. Fidelity Trust Co., 263 U.S. at 416 , and such review would "interfere with Congress's contemplated plan for [exclusive] review of state court judgments by the Supreme Court under [28 U.S.C.] $\$ 1257$," Hart \& Wechsler, 3d ed., supra note 38, at 1638. The doctrine thus does not apply in the habeas corpus context, because federal habeas corpus review of state court determinations is statutorily authorized, and Supreme Court review is not exclusive.

47. I develop these ideas more fully in 1 Liebman, supra note $24, \S 28.1$ \& nn.24-46.

48. Even Justices inclined to find federalism limitations on the power of the federal courts have given pragmatic, not federalism, reasons both for the Court's reluctance on direct review to act as trier of fact in criminal cases arising from the state courts and for the Court's endorsement of the use of federal habeas corpus courts as triers of fact in such cases. An excellent example is Justice Harlan's dissent in Beck v. Ohio, 379 U.S. 89 (1964). Justice Harlan notes that, unlike direct review in the Supreme Court, which is an unfit forum for rehearing factual questions that turn on "demeanor and credibility of witnesses, or contemporaneous understandings of the parties," federal habeas corpus, "which allows a federal court in appropriate circumstances to develop a fresh record, 
Putting aside, then, these modest differences in technique-all pragmatic, all stemming from the comparative functional advantages and disadvantages of trial, appellate, and "highest" courts-the federal review of state criminal cases available in the Supreme Court on direct review currently is the same in substance and scope as that available in the federal courts as a whole on habeas corpus. ${ }^{49}$ In each instance, state prisoners have access to a limited form of appellate review. The review is "limited" because only issues arising under the national constitution, laws, and treaties are cognizable. The review is "appellate" in the sense that one (federal) court is called upon to review the decisions of another (state) court or set of courts, ${ }^{50}$ and, as is characteristic of common law appellate procedures, the review of legal and mixed legalfactual determinations is de novo, while review of "adequate and independent" historical-factual determinations is deferential.51

Assuming only a congressional conclusion that questions of national law on which the lives and liberties of individuals depend deserve final resolution in national courts, the system of parallel review just described seems simple and logical. It gives all state prisoners the same limited appellate review, but spreads out that review among the entire

provides a far more satisfactory vehicle for resolving such unclear issues, for the judge can evaluate for himself the on-the-spot considerations which no appellate court can estimate with assurance on a cold record." Id. at 100-01 (citation omitted); see also Townsend v. Sain, 372 U.S. 293, 322 (1963) (noting comparative advantage of federal district courts on habeas corpus in obtaining "demeanor evidence" and "adjudging credibility").

49. In Part IV, 1 demonstrate that a type of parity has existed for most of American history.

50. See, e.g., Ex parte Yerger, 75 U.S. (8 Wall.) 85, 97 (1868) ("[A]n appellate jurisdiction [is one] to be exercised ... in the revision of judicial decisions."); see infra notes 218-224, 349 and accompanying text.

51. What today is called an "appeal" actually came across the Atlantic and was firmly ensconced in federal practice from 1789 until 1928 as the common law "writ of error." In early common law practice, the writ of error was simply a means of reviewing some, but not all, of the issues tried in a prior court. See Robertson \& Kirkham, supra note 14, § 104, at 194-95 (citing Cohens v. Virginia, 19 U.S. (6 Wheat.) 264, 410-11 (1821)). From the beginning, however, federal courts identified the writ of error-and distinguished it from the civil law procedure that was then called an "appeal"-by precisely the characteristic that continues to distinguish American appeals, namely, their bringing up of legal, but not factual, claims for de novo review. See Wiscart v. D'Auchy, 3 U.S. (3 Dall.) 320, 327 (1796). So sacred was the distinction between the de novo appellate review of legal questions and the limited appellate review of factual questions that ratification of the Constitution, which provides in Article IIl, $\S 2$, cl. 2, that the federal courts' appellate jurisdiction extends to both "law and fact," was made contingent upon promises to amend the document to preserve the common law practice protecting jury verdicts from redetermination on appeal. See U.S. Const. amend. VII (" $[N]$ o fact tried by a jury, shall be otherwise re-examined in any Court of the United State, than according to the rules of the common law."). So firmly rooted was the same distinction that it survived even after the writ of error was gradually replaced, during the early part of this century, with the writ of certiorari in most situations and with an "appeal" in a few situations. See Robertson \& Kirkham, supra note 14, § 104, at 195. 
federal judiciary, allocating a small number of obviously important and difficult cases to the Supreme Court on direct review; a smaller number of less obviously important and difficult cases to that Court at the end of the habeas corpus review process; and the rest to federal district courts with the intermediate possibility of final review in the courts of appeals in cases exhibiting intermediate levels of importance and difficulty. ${ }^{52}$

Simplicity and logic aside, some members of the Supreme Court want to change this system by abandoning one of its central featuresde novo review of mixed legal questions in habeas corpus proceedings. The next Part analyzes the arguments that Justice Thomas made in favor of and that Justices O'Connor and Kennedy made against that change in Wright $v$. West.

\section{Wrong and Wright: The Opposing Views of Justice Thomas AND JUSTICES O'CONNOR AND KENNEDY}

\section{A. The Questions Presented and Prescribed}

In May 1980, the Virginia Supreme Court summarily affirmed Frank Robert West's conviction for stealing $\$ 3500$ dollars worth of merchandise from a cabin in Westmoreland County, Virginia. ${ }^{53}$ The evidence against West consisted entirely of his unexplained-or, in the light most favorable to the prosecution, his falsely explained ${ }^{54}$-possession of some of the stolen merchandise. As permitted by state law (and longstanding common law), the trial court's instructions invited the jury to infer West's theft from his possession of recently stolen property.

On appeal, West argued that the evidence was insufficient to support a finding of guilt beyond a reasonable doubt. A year before, in Jackson v. Virginia, ${ }^{55}$ the United States Supreme Court for the first time had interpreted the Due Process Clause to require evidence sufficient to convince a rational juror of the defendant's guilt beyond a reasonable doubt. ${ }^{56}$ Jackson characterized this new constitutional sufficiency standard as a "mixed legal and factual" question subject to de novo federal court reconsideration on direct appeal and (as in Jackson itself) on habeas corpus. ${ }^{57}$

West did not seek certiorari. Seven years later, however, after additional postconviction proceedings in the Virginia courts, West filed a

52. See supra note 25 .

53. The facts and proceedings are descrihed in Wright v. West, $112 \mathrm{~S}$. Ct. 2482, 2484-86 (1992) (plurality opinion).

54. West testified tbat, approximately two weeks before his arrest, he had purchased the stolen merchandise "from a Ronnie Elkins" at a flea market, the location of which "I don't remember." Id. at 2484 n.1.

55. 443 U.S. 307 (1979).

56. See id. at 324 .

57. Id. at 318 . 
habeas corpus petition in the United States District Court for the Eastern District of Virginia, again alleging the constitutional insufficiency of the evidence against him. On appeal from the district court's denial of that petition, the Fourth Circuit concluded that, even as bolstered by West's testimony, which elevated the premise of the inference of theft from un explained to falsely explained recent possession, the inference did not provide sufficient evidence of West's guilt. ${ }^{58}$

On certiorari to review the Fourth Circuit's decision, Virginia mainly relied on the mistaken application of Jackson to a case in which negative inferences from the defendant's own testimony supplied sufficient evidence of guilt. ${ }^{59}$ An amici curiae brief in support of certiorari filed by a number of state attorneys general added some cachet to the petition, arguing in defense of the widely used inference of theft from possession of recently stolen goods. ${ }^{60}$ That cachet was enhanced both by a nonretroactivity issue in Virginia's petition-that the Fourth Circuit's effective invalidation of the 400-year-old inference amounted to new law ${ }^{61}$-and by the argument in the Criminal Justice Legal Foundation's amicus curiae brief that Jackson and most other "mixed questions of law and fact" should be relegated to a second tier of constitutional claims that are not cognizable in habeas corpus proceedings. ${ }^{62}$

On December 16, 1991, the Court granted certiorari on the questions Virginia presented. ${ }^{63}$ Two days later, the Court, with Justices Blackmun and Stevens dissenting, sua sponte directed the parties, and invited the Solicitor General as amicus curiae, to address the following additional question:

In determining whether to grant a petition for a writ of habeas corpus by a person in custody pursuant to the judgment of a state court, should a federal court give deference to the state court's application of law to the specific facts of the petitioner's case or should it review the state court's determination de novo? 64

The Court's order seemed to announce judgment day for the Great Writ. The guts of the habeas corpus remedy is de novo review of mixed legal and factual questions. Adoption of the Court's proposal

58. See West v. Wright, 931 F.2d 262, 268-70 (4th Cir. 1991), rev'd, Wright v. West, 112 S. Ct. 2482 (1992).

59. See Petition for Writ of Certiorari at i, 16-19, Wright v. West, 112 S. Ct. 2482 (1992) (No. 91-542).

60. See Brief of Amicus Curiae on the Merits in Support of Petitioner at 2-7, Wright v. West, 112 S. Ct. 2482 (1992) (No. 91-542).

61. See Petition for Writ of Certiorari, supra note 59, at 8-13.

62. See Brief Amicus Curiae of the Criminal Justice Legal Foundation in Support of the Petition for Writ of Certiorari at i, 3-12, Wright v. West, 112 S. Ct. 2482 (1992) (No. 91-542). The Foundation abandoned this argument in its amicus curiae brief on the merits after the habeas corpus modification the Court proposed in its order granting certiorari leap-frogged the Foundation's less radical proposal.

63. See Wright v. West, 112 S. Ct. 656 (1991) (mem.).

64. Wright v. West, 112 S. Ct. 672 (1991) (mem.). 
would be a serious, perhaps mortal, blow to the writ's function as a substitute for the review the petitioner would have received had the Supreme Court the resources to review the case.

The Court took three paragraphs to reach the outcome of Wright, which was pure anticlimax. ${ }^{65}$ Whatever might have been the case had West kept his own counsel, his trip to the witness stand to offer a lessthan-credible explanation for possessing the recently stolen items, coupled with the possession itself, provided all the evidence needed to find him guilty of theft. But the remaining fifty-five paragraphs of legal analysis in four separate opinions, all of them dicta, most of them set forth in the form and tone of legal briefs, are pure ante-climax-a call to arms for the final battle to come.

\section{B. A Critical Analysis of Justice Thomas'Arguments Against De Novo Habeas Corpus Review}

1. Summary of (a Conservative's) Argument: A Radical Reform Rejected as Too Much, Too Recent, Too Short-Lived. - Justice Thomas begins his arguments against de novo habeas corpus review by arguing that it is a recent phenomenon in the United States. ${ }^{66}$ For roughly the first eighty-five years of the nation's existence, according to Justice Thomas, only the rarest of legal claims - "challenge[s to] the jurisdiction of the court that had rendered the judgment under which [the petitioner] was in custody"-were cognizable in habeas corpus. ${ }^{67}$ Thereafter, the number of cognizable claims slowly mounted, stair-step fashion, beginning in 1874 with claims of punishment under a "sentence not authorized by statute," 68 progressing in 1879 to claims of conviction "under [an] unconstitutional statute,"69 and then in 1915 and 1923 to all "federal claims by state prisoners if no state court had provided a full and fair opportunity to litigate those claims."70 Before 1953, however, "absent an alleged jurisdictional defect, "habeas corpus would not lie for [a state] prisoner ... given an adequate opportunity to obtain full and fair consideration of his federal claim in the state courts." "71 Accordingly, it was only in Brown v. Allen 72 in 1953 that the Court opened up habeas corpus to "constitutional claims [generally], even if the state court has

65. See Wright v. West, 112 S. Ct. 2482, 2492-93 (1992).

66. See id. at $2486-87$ (plurality opinion).

67. Id. at 2486 (citing In re Wood, 140 U.S. 278, 285-87 (1891), and Ex parte Watkins, 28 U.S. (3 Pet.) 193, 202 (1830)).

68. Id. (plurality opinion) (citing Ex parte Lange, 85 U.S. (18 Wall.) 163, 176 (1874)).

69. Id. (plurality opinion) (citing Ex parte Siebold, 100 U.S. 371,377 (1879)).

70. Id. (plurality opinion) (citing Moore v. Dempsey, 261 U.S. 86, 91-92 (1923), and Frank v. Magnum, 237 U.S. 309, 335-36 (1915)).

71. Id. (plurality opinion) (quoting Fay v. Noia, 372 U.S. 391, 459-60 (1963) (Harlan, J., dissenting), questioned in Wainwright v. Sykes, 433 U.S. 72, 87-88 (1977), and overruled by Coleman v. Thompson, 111 S. Ct. 2546, 2565 (1991)).

72. 344 U.S. 443 (1953). 
rejected all such claims after a full and fair hearing."73

Justice Thomas attributes this historical analysis to Justice Harlan, but the analysis-down to the decisions whose names are inscribed on each of the stair steps of expanded cognizability ${ }^{74}$-is Paul Bator's. ${ }^{75}$ Although Bator's neat historical progression of ever-expanding judicial cognizability has a pleasingly Whiggian cast to it, Justice Thomas uses the point (as did Justice Harlan and Professor Bator) in a decidedly anti-Whiggian fashion, to suggest that current conditions arrived too recently, and preexisting conditions changed too much and too rapidly, to give current conditions any precedential credence. ${ }^{76}$

Professor Bator first made this point just ten years after Brown allegedly took the last, largest, and least credible step in the progression. Making the same "too much change too recently" point tell today, some forty years after Brown, obviously presents a problem. For that reason, perhaps, Justice Thomas deviates at this point from the Batorian orthodoxy. What Bator saw as a giant stair step constructed in 1953, Justice Thomas sees as only a smaller step attached to an imperceptibly rising ramp that reached the existing level of habeas corpus review only in Miller v. Fenton 77 in 1985. Thus, in considering the question of how carefully habeas corpus courts were to scrutinize the raft of state court constitutional determinations newly thrust before them by Brown, Justice Thomas claims that Brown actually demanded only that "the statecourt adjudication 'ha[ve] resulted in a satisfactory conclusion." "78 In support of the view that a "satisfactory" conclusion did not necessarily mean "one that the habeas court considered correct, as opposed to merely reasonable," Justice Thomas quotes Justice Reed's statement in Brown that:

As the state and federal courts have the same responsibilities to protect persons from violation of their constitutional rights, we conclude that a federal district court may decline, without a rehearing of the facts, to award a writ of habeas corpus to a state prisoner where the legality of such detention has been determined, on the facts presented, by the highest state court with jurisdiction. ${ }^{79}$

73. Wright v. West, 112 S. Ct. at 2487 (plurality opinion) (citing Brown v. Allen, 344 U.S. at 458).

74. See supra notes $67-73$ and accompanying text.

75. See Bator, supra note 6, at 465-507. Bator's article is acknowledged both in Justice Harlan's dissent in Fay v. Noia, 372 U.S. at 449 n.l, and, via a "See generally" citation, in Justice Thomas' opinion in Wright v. West, 112 S. Ct. at 2486 (plurality opinion).

76. See Wright v. West, 112 S. Ct. at $2486-87$ (plurality opinion); Fay v. Noia, 372 U.S. at 457-63 (Harlan, J., dissenting); Bator, supra note 6, at 500-07.

77. 474 U.S. 104 (1985).

78. Wright v. West, $112 \mathrm{~S}$. Ct. at 2487 (plurality opinion) (quoting Brown v. Allen, 344 U.S.443, 463 (1953) (opinion of Reed, J.)).

79. Id. at $2487-88$ (plurality opinion) (quoting Brown v. Allen, 344 U.S. at 465 (opinion of Reed, J.)). 
Justice Thomas also quotes Justice Frankfurter's statements in Brown that "a "prior determination may guide [the] discretion [of the district court] in deciding upon the appropriate course to be followed in disposing of the application" " and "that 'there is no need for the federal judge, if he could, to shut his eyes to the State consideration." "80

Justice Thomas acknowledges that de novo review of legal and mixed legal-factual questions was the rule by the late 1980 s, but he characterizes that development as having taken place slowly and essentially by accident:

In subsequent cases, we repeatedly affirmed Brown's teaching that mixed constitutional questions are "open to review on collateral attack," Cuyler v. Sullivan, 446 U.S. 335, 342 (1980), without ever explicitly considering whether that "review" should be de novo or deferential. . . . Nonetheless, because these [1960s, 1970s, and 1980s] cases never qualified our early citation of Brown for the proposition that a federal corpus court must reexamine mixed constitutional questions "independently," Townsend v. Sain, 372 U.S. 293, 318 (1963) (dictum), we have gradually come to treat as settled the rule that mixed constitutional questions are "subject to plenary federal review" on habeas. Miller v. Fenton, 474 U.S. 104, 112 (1985). ${ }^{81}$

Relying on its curious chronology, this paragraph argues, in essence, that de novo review arose only in 1985, when the Court transformed Townsend v. Sain's "dictum" into the holding of Miller v. Fenton. In this way, Justice Thomas constructs an anti-Whiggian dream argument. Miller v. Fenton endorsed the de novo review rule on the basis of stare decisis. ${ }^{82}$ As such, Justice Thomas claims, the existing de novo review rule deserves only minimal credence because the Court accepted it only recently, by mistakenly treating as foregone what never previously had occurred.

Next, having shortened the pedigree of broad habeas corpus review from 1789 to late 1985 , Justice Thomas proceeds to supplement his "too much, too soon" attack on de novo habeas corpus review with a

80. Id. at 2488 (plurality opinion) (citations omitted) (quoting Brown v. Allen, 344 U.S. at 500, 508 (opinion of Frankfurter, J.)).

8I. Id. at $2488-89$ (plurality opinion).

82. See Miller v. Fenton, 474 U.S. 104, 115 (1985). The passage quoted in text does not actually specify 1985 as the date on which de novo review first occurred, but only as the date on which that reform can be said to have "gradually" come to be "settled." Wright v. West, 112 S. Ct. at 2489 (plurality opinion). But having initially said only that de novo review arose sometime before 1985, Justice Thomas tbereafter identifies 1985 as the year in which it did occur, thus squeezing as many months and years as possible out of the period in which the rule has been settled. See id. at 2491. Justice Thomas' ultimate position seems to be that the de novo review rule was not even accepted as of 1985. See id. at 2489 (discussing Court's "apparent adherence to a standard of de novo habeas review with respect to mixed constitutional questions" in the post-Miller period (emphasis added)). 
"too short" critique. He contends that the Court's 1989 nonretroactivity decision in Teague $v$. Lane ${ }^{83}$ drastically-albeit only implicitly-limited the de novo review rule. ${ }^{84}$ For Thomas, the importance of Teague's nonretroactivity doctrine is not so much its preclusion of habeas corpus claims premised on new rules of law as its definition of "new rules" as "all rules 'susceptible to debate among reasonable minds." "85 Thus, if a state court applying existing law has reasonably rejected a claim, the habeas corpus petitioner cannot thereafter secure relief on the claim without gaining the benefit of a "new rule," which is forbidden under Teague. ${ }^{86}$ "In other words," Justice Thomas continues, whatever may have been the case between 1985 and 1989, today "a federal habeas court 'must defer to the state court's decision rejecting the claim unless that decision is patently unreasonable." "87

Justice Thomas thus transforms the broad habeas corpus review of federal constitutional claims that Justice Harlan and Professor Bator found "too much" of and "too recent" a reform in 1963 into one that did not even occur until 1985, and was thereafter rendered "too short" by its emasculation in 1989 .

Finally, the trap set by Justice Thomas' "incredible shrinking" history of the Great Writ slams shut:

In light of these principles, petitioners ask that we reconsider our statement in Miller $v$. Fenton that mixed constitutional questions are "subject to plenary federal review" on habeas. By its terms, Teague itself is not directly controlling, because West sought federal habeas relief under Jackson [v. Virginia], which was decided a year before his conviction became final on direct review. Nonetheless, petitioners contend, the logic of Teague makes our statement in Miller untenable. Petitioners argue that if deferential review for reasonableness strikes an appropriate balance with respect to purely legal claims, then it must strike an appropriate balance with respect to mixed questions as well ... [especially given] that under the habeas statute itself, a state-court determination of a purely factual question must be "presumed correct," and can be overcome only by "convincing evidence," unless one of eight statutorily enumerated exceptions is present. It makes no sense, petitioners assert, for a habeas court generally to review factual determinations and legal determinations deferentially, but to review applications of law to fact de novo. ${ }^{88}$

Encapsulated, Justice Thomas' argument runs thus: De novo review of legal claims in habeas corpus? Sure, we accidentally stumbled into

83. 489 U.S. 288 (1989).

84. See Wright v. West, 112 S. Ct. at 2489 (plurality opinion).

85. 1d. at 2489-90 (quoting Butler v. McKellar, 494 U.S. 407, 415 (1990)).

86. See Wright v. West, 112 S. Ct. at 2490 (plurality opinion).

87. 1d. (quoting Butler v. McKellar, 494 U.S. at 422 (Brennan, J., dissenting)).

88. 1d. at 2491 (plurality opinion) (citations omitted). 
that rule for a few years in the mid-to-late 1980s. But we corrected our error implicitly in some decisions decided a few years later, and now ought to correct it explicitly as well.

2. Surface Analytical Shortcomings. - Justice Thomas' classically conservative rhetorical strategy is unconvincing. First, consider only some analytical problems that appear on the face of the opinion, beginning with a rhetorical move that may have been designed to be transparent. In his last paragraph on habeas corpus, Justice Thomas suddenly switches from declaiming the plurality's own views about the history of habeas corpus to reporting the views that "petitioners ask that we" adopt. ${ }^{89}$ This trope gives Justice Thomas a speck of cover as he transits from his nineteen-paragraph flight of dicta on habeas corpus to his three-paragraph resolution of the case on a mundane criminal procedure ground ${ }^{90}$ _namely, that he was merely providing the usual summary of the parties' positions. Not least because ninety percent of this not-so-usual summary is devoted to one side's position, 91 there can be little doubt of the ownership of the views that the Court's own order directed "petitioners [to] ask" that the Court adopt.

Next consider Justice Thomas' deflation of the historical scope of habeas corpus review. Notice that Justice Thomas' entire discussion of pre-1953 habeas corpus review deals exclusively with the limited range of cognizable claims. ${ }^{92}$ Not a word is said about the scope of review of the claims that were, concededly, cognizable-the issue the Court put at stake in Wright. ${ }^{93}$ On that question, Justice Thomas' opinion reveals not a whit about the pre-1953 history.

Justice Thomas attempts to camouflage this discrepancy by stating that before 1953, unless the state court decision implicated a cognizable claim, the decision was "entitled to 'absolute respect" " in habeas corpus proceedings. ${ }^{94}$ This characterization is no more accurate, however, than a statement that, when a federal court refuses to hear a diver-

89. Id.

90. See id. at 2492-93.

91. See id. at $2486-91$.

92. Justice 'Thomas' discussion of the pre-1953 history paraphrases Bator's and Harlan's. Yet Professor Bator believed that the Court exercised de novo review of legal claims (i.e., "ordinary review on the merits") from the moment it acquired jurisdiction under the 1867 habeas corpus act in 1885 . See Bator, supra note 6 , at 479 . Although Bator opposed de novo review of mixed questions by the Supreme Court on direct review, he argued forcefully that, if such review was available on direct review, it also, in fairness, should be available on habeas corpus review. See id. at 502-11. Justice Harlan favored de novo review of mixed questions in both situations. See Beck v. Ohio, 379 U.S. 89, 100-01 (1964) (Harlan, J., dissenting); Fay v. Noia, 372 U.S. 391, 459-60 (1963) (Harlan, J., dissenting) (quoted infra at text accompanying note 168), questioned in Wainwright v. Sykes, 433 U.S. 72, 87-88 (1977), and overruled by Coleman v. Thompson, 111 S. Ct. 2546, 2565 (1991).

93. See supra note 64 and accompanying text.

94. Wright v. West, $112 \mathrm{~S}$. Ct. at 2486 (plurality opinion) (quoting Kuhlmann v. Wilson, 477 U.S. 436, 446 (1986) (plurality opinion)) (emphasis omitted). 
sity action in which less than $\$ 50,000$ is in controversy, it is paying "absolute" deference to any determination a state court with jurisdiction might reach. ${ }^{95}$ Using this same approach, one could argue-based on the rule that exclusively state-law claims are not cognizable in habeas corpus proceedings ${ }^{96}$ - that because the federal courts must pay "absolute deference" to state courts' resolution of state law claims, federal courts also should be required to defer absolutely to state courts' resolution of claims that are cognizable.

Nor do we learn anything from Justice Thomas' opinion about the standard of review of cognizable legal claims after 1953. His quotation of Justice Reed's conclusion in Brown, "that a federal district court may decline, without a rehearing of the facts, to award a writ of habeas corpus to a state prisoner where the legality of such detention has been determined, on the facts presented, by the highest state court with jurisdiction," "97 says exactly nothing about whether a federal court may decline to award a writ of habeas corpus without a rehearing of the law.

Justice Frankfurter's statement, quoted by Justice Thomas, "that 'there is no need for the federal judge, if he could, to shut his eyes to the State consideration" "98 is likewise uninformative on the desired standard of review. The statement says only the obvious-that the reviewing court, in making its independent judgment, might find it edifying to read what another court in the same case, on the same facts, has said about the same legal issue. The same point can be made by drawing on a more familiar context: That the Supreme Court on direct review of constitutional legal questions does not blind itself to the persuasive views of other courts and commentators does not mean that it "defers" to their judgments.

Justice Thomas thus gives no clues to the Court's understanding of the standard of review of cognizable claims even after Brown came down in 1953. Indeed, cleared of the underbrush, all Justice Thomas' habeas corpus history reveals about the standard of review is that, at some time in or before 1985, the Court had "come to treat as settled the rule that mixed constitutional questions are 'subject to plenary federal review' on habeas."99

Coming then to Teague, Justice Thomas uses the connecting word "Thus" to equate what on inspection are two quite different principles.

95. Ironically, having used the stratagem himself, Justice Thomas criticizes Justice O'Connor for confusing cognizability and standard of review rules. See id. at $2489 \mathrm{n} .7$ (plurality opinion).

96. See, e.g., Estelle v. McGuire, 112 S. Ct. 475, 480, 481-82 (1991).

97. Wright v. West, $112 \mathrm{~S}$. Ct. at 2488 (plurality opinion) (quoting Brown v. Allen, 344 U.S. 443, 465 (1953) (opinion of Reed, J.)) (emphasis added); see supra note 80 and accompanying text.

98. Wright v. West, $112 \mathrm{~S}$. Ct. at 2488 (plurality opinion) (quoting Brown v. Allen, 344 U.S. at 508 (opinion of Frankfurter, J.)).

99. Id. at 2489 (plurality opinion) (quoting Miller v. Fenton, 474 U.S. 104, 112 (1985)). 
First is the Teague principle that in deciding what rule of law to apply, a habeas corpus court must discard any rule relied on by the petitioner that was "susceptible to debate among reasonable minds" at the time of the petitioner's direct appeal proceedings. ${ }^{100}$ Second is the quite different principle (not adopted in Teague) that, once having used the "reasonable minds could differ" standard to ascertain the "old" rule of law that governs, "a federal habeas court [additionally] 'must defer to the state court's decision rejecting the claim unless that decision is patently unreasonable." "101 The two principles are different, of course, because "debate" over a rule's content is not the same thing as debate over its application once its content has been ascertained.

Consider two more analytical problems. In support of a rule of deferential legal review, Justice Thomas notes that, "under the habeas statute itself, a state-court determination of a purely factual question must be 'presumed correct,' and can be overcome only by 'convincing evidence." 102 The first problem is in leaving unsaid what any reader of Civil Procedure Rule 52(a) or the Seventh Amendment, to name but two sources, must know: Common law practice has long not only tolerated, but actually required, that reviewing courts exercise widely different standards of review in examining the legal determinations and the factual findings of a prior court. ${ }^{103}$

The second problem in the same passage appears in the curious word "itself" with which Justice Thomas modifies his lone reliance on the habeas corpus statute. In that word lurks an assumption that the statute is the last or, at least, not a very rewarding, place to look for the standard of legal review that the statute adopts. In fact, the statute says quite a lot about standards of review in habeas corpus proceedings. ${ }^{104}$ Apart from the statute's requirement of deferential fact review, however, nothing it says appears in Justice Thomas' opinion.

On analysis, Justice Thomas' opinion supports only four limited conclusions about habeas corpus review from 1789 to the present: First, at points prior to 1953 , there were fewer cognizable claims than

100. Butler v. McKellar, 494 U.S. 407, 415 (1990); accord supra notes 42-44 and accompanying text.

101. Wright v. West, 112 S. Ct. at 2490 (plurality opinion) (quoting Butler v. McKellar, 494 U.S. at 422 (Brennan, J., dissenting)). Applied to confession claims, Thomas' double-deference test would require federal judges not only to apply the "voluntariness" test, because no reasonable jurist could think that any other test applies, but also to defer to erroneous but "reasonable" state court applications of that test. In effect, the double-deference rule says the following to the state court being reviewed: "The rule you applied deviates from the rule that any rational jurist would have applied. As a result, the petitioner is in prison (or will be executed). We uphold your decision anyway, because the extent of your irrationality is 'reasonable." "

102. Id. at 2491 (plurality opinion) (emphasis added) (quoting 28 U.S.C. $§ 2254$ (d) (1988)).

103. See supra notes $12-18,28-34,51$ and accompanying text.

104. See infra notes $376-389,516,522$ and accompanying text. 
after that year, to which some unspecified standard of review of legal questions was applied. Second, at some unspecified point prior to 1985, that standard of review of legal and mixed legal-factual claims was de novo. Third, since 1989, habeas corpus courts choosing between the rule the state courts applied and a later rule on which the petitioner relies have been forbidden to use the petitioner's rule if reasonable judges could have disagreed about its applicability at the time the petitioner sought direct review in the Supreme Court. Fourth, there is a statute involved, which requires deferential fact review.

Whatever else might be said about these four conclusions, they are entirely consistent with the dual system of "limited federal appellate review" of criminal convictions laid out in Part 1 above.

3. Analytical Shortcomings Slightly Below the Surface. - Justice Thomas' discussion of the Supreme Court's habeas corpus decisions makes no case for jettisoning the "settled" rule of de novo habeas corpus review of legal and mixed legal-factual questions. But what of the decisions themselves? Digging just below the surface of Justice Thomas' opinion, do we find any support in those decisions for his antiWhiggian effort to isolate the de novo review rule as too much, too recent, and too short-lived a reform to deserve any credence?

a. Before Brown v. Allen. - Justice Thomas' pre-1953 history is Professor Bator's, and, in Parts III and IV, it will require going well below the surface of the pre-1953 decisions to discover the flaws in that analysis. Suffice it here to make two comments. First, Justice Thomas accurately paraphrases the Batorian history for the limited point the history supports-that the claims cognizable in habeas corpus were originally few and expanded only slowly, stair-step style, through 1953. Second, that history by now is eminently respectable-indeed black letter, thanks to its enshrinement in opinions by Justices Harlan and Powell and in the Hart and Wechsler holy writ. ${ }^{105}$

b. Brown v. Allen: Justice Reed's Majority Opinion. - Coming then to Brown $v$. Allen, ${ }^{106}$ the first point to emphasize is that, fast approaching its fortieth birthday, the decision has been the law of the land during twenty percent of the nation's history. The rhetorical punch Professor Bator derived from the decision's tender age in 1963 is lost now, and the decision may well be the pre-1954 Supreme Court decision that lower federal courts most frequently have relied on since then. ${ }^{107}$ Brown by now is a Supreme Court classic.

105. See, e.g., Kuhlmann v. Wilson, 477 U.S. 436, 453 (1986) (Powell, J., for the plurality); Stone v. Powell, 428 U.S. 465, 476 (1976) (Powell, J., for the majority); Fay v. Noia, 372 U.S. 391, 449-63 (1963) (Harlan, J., dissenting), questioned in Wainwright v. Sykes, 433 U.S. 72, 87-88 (1977), and overruled by Coleman v. Thompson, $111 \mathrm{~S}$. Ct. 2546, 2565 (1991); Hart \& Wechsler, 2d ed., supra note 38, at 1428-29, 1465-77.

106. 344 U.S. 443 (1953).

107. Lexis reports 1196 citations to Brown v. Allen, 344 U.S. 443 (1953), in its "Genfed" file of federal decisions. Citation is not reliance, of course, but even just considering decisions since the mid-1980s, making no effort to be comprehensive, and 
Brown has two majority opinions-one by Justice Reed, another by Justice Frankfurter. ${ }^{108}$ The criticism often directed at Justice Reed because of the terseness of his opinion on the cognizability of claims and the scope of review is unfair. ${ }^{109}$ Twice before Brown, in Hawk v. Olson ${ }^{110}$ and Darr v. Burford, ${ }^{11}$ Justice Reed extensively laid out the Court's views on the Great Writ. His terseness in Brown accordingly is a manifestation, not of uncertainty, but instead of an explicit decision to incorporate and rely on the Court's opinions in Hawk and Darr. ${ }^{12}$

The cited passages in Hawk and Darr clearly reveal Justice Reed's broad view of both the cognizability and standard of review issues. On cognizability, the two decisions make clear that well before Brown, " $[t]$ he writ ... command[ed] general recognition as the essential remedy to safeguard a citizen against imprisonment by State or Nation in violation of" apparently any and all of "his constitutional rights."113 On the standard of review, Hawk and Darr likewise make clear that federal habeas corpus courts have "the responsibility to review the state

analyzing only one of several facets of Brown's meaning for modern federal courts, my treatise collects 166 post-Brown circuit court decisions affording de novo review of mixed questions of fact and law. See 1 Liebman, supra note $24, \S 20.3 \mathrm{~d} n$ n.24-57.5 (including 1992 Supp.).

108. See Brown v. Allen, 344 U.S. 443, 452-65 (1953) (opinion of Reed, J.); id. at 488 (opinion of Frankfurter, J.). The reporter's syllabus, id. at 443, Justice Reed's opinion, id. at 452, a reporter's note introducing the Frankurter opinion, id. at $488 \mathrm{n}$.*, and Justice Frankfurter's opinion, id. at 497 , all characterize the Frankfurter opinion, including its discussion of the standard of review, as an opinion of the Court. See, e.g., Wainwright v. Sykes, 433 U.S. 72, 79, 87 (1977); Henry M. Hart, Foreword: The Time Chart of the Judges, 73 Harv. L. Rev. 84, 106 n.64 (1959). In addition to discussing cognizability and the standard of review, Justice Reed's opinion resolves the cases before the court, id. at 465-87 (opinion of Reed, J.), with Justice Frankfurter dissenting in part, id. at 554 (Frankfurter, J., dissenting), and Justice Frankfurter's opinion decides the impact of a denial of certiorari on subsequent habeas corpus proceedings, id. at 489-97 (opinion of Frankfurter, J.), with Justice Reed dissenting, id. at 456-57 (opinion of Reed, J.).

109. See Hart \& Wechsler, 2d ed., supra note 38, at 1473 ("On the question of the appropriateness of exercising habeas corpus jurisdiction, Justice Reed simply assumes that the federal habeas court must redetermine the constitutional issue on the merits."); Brief Amicus Curiae of the Criminal Justice Legal Foundation, at 15, Wright v. West, 112 S. Ct. 2482 (1992) (No. 91-542) [hereinafter CJLF Brief] (calling Reed's opinion on the standard of review "opaque").

110. 326 U.S. 271 (1945).

111. 339 U.S. 200 (1950), overruled on other grounds by Fay v. Noia, 372 U.S. 391 (1963).

112. See Brown v. Allen, 344 U.S. at 452 (citing Hawk v. Olson, 326 U.S. at 274; Darr v. Burford, 339 U.S. at 203).

113. Darr v. Burford, 339 U.S. at 203 (citing Hawk v. Olson, 326 U.S. at 274). Bator notwithstanding, all nine members of the Brown Court believed that habeas corpus had opened up to all constitutional claims well before 1953. See Brown v. Allen, 344 U.S. at 452 (opinion of Reed, J.); id. at 498-501 (opinion of Frankfurter, J.), id. at 549 (Black, J., dissenting); id. at 532-33 \& n.4 (Jackson, J., dissenting) (acknowledging the availability of habeas corpus for all due process violations but lamenting Court's expansion of Due Process Clause). 
proceedings."114 When the "[p]etitioner states a good cause of action ... that through denial of asserted constitutional rights he has not had the kind of trial in a state court which the due process clause of the Fourteenth Amendment requires," and when he "prove[s] his allegations," relief is required. ${ }^{15}$

In only one instance did Justice Reed believe that the prior adjudication of the legal issues in the prisoner's habeas corpus petition might deserve deference. If on prior applications to the federal courts, "the merits . . . have already been decided against the petitioner," a federal court entertaining a second application "may," but need not, "decline to examine furtber."116 In Reed's view, these potentially preclusive prior federal adjudications on "the merits" included not only review of prior federal habeas corpus applications 117 and prior Supreme Court grants of certiorari on direct appeal, ${ }^{118}$ but also-in a view subsequently rejected in Brown ${ }^{119}$ - the Supreme Court's denial of certiorari on direct appeal. ${ }^{120}$

Incorporation by reference aside, Justice Reed's discussion of the standard of review issue in Brown itself is far less elliptical than often is claimed. Indeed, a three-page passage in his opinion is a veritable compendium of progressively more muscular standards of federal review applied in different habeas corpus contexts. According to Reed, in habeas corpus review of state court decisions, total deference is due a decision premised on an adequate and independent state ground; ${ }^{121}$ substantial deference is due a fairly achieved state court determination of fact;"122 and "some" deference is due a prior federal determination of the same claim in an earlier petition in the same case, including a prior Supreme Court denial of certiorari on direct appeal. ${ }^{123}$ Then, at the most muscular end of the standard-of-review continuum, comes the crucial sentence covering the standard of review of legal claims previously adjudicated by state courts: "In other circumstances, the state adjudica-

114. Hawk v. Olson, 326 U.S. at 276; see Darr v. Burford, 339 U.S. at 216-18.

115. Hawk v. Olson, 326 U.S. at 278-79; see also Bator, supra note 6, at 479 (as early as 1886, Court "seemingly equate[d] the substantive scope of the habeas jurisdiction with ordinary review on the merits"); Hart, supra note 108, at 105-06 (charting development of de novo habeas corpus review of state court resolution of due process challenges).

116. Darr v. Burford, 339 U.S. at 215.

117. See id. at 214-15 (discussing Salinger v. Loisel, 265 U.S. 224 (1924)); see also Brown v. Allen, 344 U.S. 443, 456-57 (1953) (opinion of Reed, J.) (discussing same).

118. See Darr v. Burford, 339 U.S. at 224 (Frankfurter, J., dissenting) (reading Justice Reed's majority opinion to require deference to prior Supreme Court adjudications on grant of certiorari).

119. See Brown v. Allen, 344 U.S. at 489-97 (opinion of Frankfurter, J.).

120. See Darr v. Burford, 339 U.S. at 214-15 (citing Salinger v. Loisel, 265 U.S. 224 (1924)); cases cited infra note 519.

121. See Brown v. Allen, 344 U.S. at 458 (opinion of Reed, J.).

122. See id. at 458.

123. See id. at $456-57$. 
tion carries the weight that federal practice gives to the conclusion of a court of last resort of another jurisdiction on federal constitutional issues. It is not res judicata." 124

Reed obviously knew well how to prescribe a rule of deference, and this passage was the perfect place to do so, if he thought that a deference rule should apply to habeas corpus review of state court legal determinations. Yet he prescribed nothing of the sort.

More importantly, consider what Reed actually said: The state supreme court's resolution of the federal legal question in the case at hand is due exactly as much attention as the decision of any other state supreme court on the same point. Either decision is what used to be called "persuasive legal authority," a category that includes-among many other things to which "respect" but not "deference," stricti juri, is due-Blackstone's Commentaries, Justinian, dissenting opinions by Holmes, Brandeis and both Harlans, all manner of English decisions, and (in desperation) even law review articles. Indeed, Justice Reed directed lower federal courts to pay to state court legal determinations exactly the attention that state courts often claim to pay lower federal court precedents in the course of politely refusing to defer to them.125

In short, Justice Reed's opinion invites federal habeas corpus courts to behave towards state court legal determinations exactly as the Supreme Court behaves on direct review. It was no doubt for that reason that Justice Reed indiscriminately annotated his discussion of the standard of review issue with citations not only of habeas corpus cases but also of Supreme Court opinions on direct review of state criminal judgments. ${ }^{126}$

Reed did not just prescribe de novo review; he exercised it. Noting that the resolution of the particular cases before the Court depended on whether "petitioners received [trials] consonant with standards accepted by this Nation as adequate to justify their convictions" because they "lie in the compass of the Due Process and Equal Protection Clauses of the Fourteenth Amendment," 127 Justice Reed reviewed the constitutional issues in a microscopic fashion that can only be called de novo. ${ }^{128}$ Indeed, Reed overlooked the lower federal courts' erroneous

124. Id. at 458 .

125. See Bradshaw v. State, 286 So. 2d 4, 6 (Fla. 1973), cert. denied, 417 U.S. 919 (1974) ("[A] decision of a federal trial court, while persuasive if well-reasoned, is not by any means binding on the courts of a state."); Dugas v. State, 277 A.2d 620, 621 (Md. App. 1971) (" $[A]$ lthough a decision of the Fourth Circuit is entitled to respect, it is not binding upon us [i.e., upon a Maryland appellate court]."); see also Robert M. Cover \& T. Alexander Aleinikoff, Dialectical Federalism: Habeas Corpus and the Court, 86 Yale L.J. 1035, 1052-53 \& n.82 (1977) (citing cases).

126. See Brown v. Allen, 344 U.S. at 458-59 \& n.8 (citing Malinski v. New York, 324 U.S. 401 (1945) (direct review); Ex parte Hawk, 321 U.S. 114 (1944) (habeas corpus); Mooney v. Holohan, 294 U.S. 103 (1935) (same)).

127. Brown v. Allen, 344 U.S. at 465 (opinion of Reed, J.) (emphasis added).

128. See Brown v. Allen, 344 U.S. at 465, 465-87 (opinion of Reed, J.); see also 
expressions of deference to the Court's prior denials of certiorari ${ }^{129}$ only because the lower federal courts did not defer to the state court judgments, but instead "recognized the power of the District Court to reexamine federal constitutional issues even after trial and review by a state."130 Perhaps most tellingly, Reed held that, even if the admission of the confession in Brown were harmless, habeas corpus relief was still required if the confession was unconstitutionally secured. ${ }^{131}$ It is hard to imagine less deference to an erroneous state court legal determination than a decision to reverse the determination though it made no difference to the outcome.

How much of Justice Reed's pointed remarks on the standard of review question makes it into Justice Thomas' paraphrase forty years later? By expositional sleight of hand, the core of Justice Reed's analysis disappears. Justice Thomas dutifully reprises Justice Reed's lesserincluded-conclusion that "a state-court judgment of conviction is not res judicata," " but leaves out the greater-including statement just preceding it-that respect, but not deference, is due the state court judgment. ${ }^{132}$ Equally troubling is Justice Thomas' diligent quotation of Justice Reed's views on the deference due state court factual findingsmisleadingly described as Justice Reed's views on "the federal courts['] ... discretion to take into consideration the fact that a state court has previously rejected the federal claims asserted on habeas"133-at the same time as he ignores Reed's quite differently formulated views on the deference due state court legal determinations.

c. Brown v. Allen: Justice Frankfurter's Majority Opinion. - Because Justice Reed so clearly ensconced a de novo review rule in his opinion for the Court in Brown, the imprecision Justice Thomas claims to find in Justice Frankfurter's second majority opinion hardly matters. But being in fact even more explicit, Frankfurter's reiteration deserves attention.

Having emphasized his "sharp" disagreement with Justice Reed's view of the weight due prior Supreme Court denials of certiorari in habeas corpus proceedings, Justice Frankfurter was at pains to express his agreement with Justice Reed's view of "the bearing of the proceedings in the State courts upon the disposition of the application for a writ of habeas corpus in the Federal District Courts"134 - that such

United States ex rel. Smith v. Baldi, 344 U.S. 561, 565-70 (1953) (affording de novo review to case decided same day as Brown).

129. Having expressed, but acknowledged defeat on, his view that prior denials of certiorari deserve deference, Justice Reed then applied the majority's view that no deference is appropriate. See Brown v. Allen, 344 U.S. at 452, 459 (opinion of Reed, J.).

130. Id. at 459 (emphasis added).

131. See id. at 475 .

132. Wright v. West, 112 S. Ct. 2482,2487 (1992) (plurality opinion) (quoting Brown v. Allen, 344 U.S. at 458 (opinion of Reed, J.)).

133. Id. at 2487 (plurality opinion) (emphasis omitted).

134. Brown v. Allen, 344 U.S. at 497 (opinion of Frankfurter, J.). 
proceedings merit not deference, but the same respect that the federal court would give to a state court opinion on the same point announced in any other litigant's case. Notwithstanding Justice Thomas' claim in Wright that the Brown Court "had no occasion to explore in detail" whether state-court adjudications of legal questions "were [to be] reconsidered de novo," 135 Justice Frankfurter's majority opinion expressly treated Brown as an occasion to explore, "explicit[ly] and [in] detail[]," 136 exactly that question. Let's consider, then, how successfully Justice Frankfurter accomplished that task.

As Henry Hart wryly commented in 1959, "Mr. Justice Frankfurter ... never seems to be wanting in deference to the states." 137 It is hardly surprising, then, to find Justice Frankfurter commencing his discussion of standards of review by protesting that "no one can feel more strongly than I do" about the importance of leaving states free to pursue "the sturdy enforcement of their criminal laws."138 What does seem surprising, however, is Justice Frankfurter's repeated identification of a yet higher responsibility-the mandate of the habeas corpus statute-that pulled him reluctantly in the opposite direction: "It is not for us to determine whether th[e habeas corpus review] power should have been vested in the federal courts," for "there seems to be no escape from the law." "139

What statutory compulsion, then, warranted all these apologies from the great deferrer? "Our problem," Justice Frankfurter explained, "arises because Congress has told the District Judge to act on those occasions, however rare, when there are meritorious causes in which habeas corpus is the ultimate and only relief and designed to be such."140 The deferrer's "problem," thus, was precisely that constitutional merit itself, rather than the reasonableness of the state courts' inattention to it, was the statutory trigger for federal court intervention.

From the following passage, which intervenes at about this point in Justice Frankfurter's opinion, Justice Thomas extracts a sentence-the second sentence italicized below-and presents it as emblematic of Frankfurter's views:

135. Wright v. West, 112 S. Ct. at 2487 (plurality opinion).

136. Brown v. Allen, 344 U.S. at 497 (opinion of Frankfurter, J.).

137. Hart, supra note 108 , at 107 n.68.

138. Brown v. Allen, 344 U.S. at 498 (opinion of Frankfurter, J.).

139. Id. at 499 (opinion of Frankfurter, J.) (quoting Ex parte Bridges, 4 F. Cas. 98, 106 (C.C.N.D. Ga. 1875) (No. 1,862) (Bradley, Cir. J.)).

140. Id. at 501. By Congress, Justice Frankfurter meant, specifically, "the [Habeas Corpus] Act of 1867," ch. 28, 14 Stat. 385 (1867) (current version at 28 U.S.C. $\$ 2241$ et seq.). Brown v. Allen, 344 U.S. at 499 (opinion of Frankfurter, J.). Justice Reed agreed both that "[j]urisdiction over applications for federal babeas corpus is controlled by statute," id. at 460 (opinion of Reed, J.), and that it was "the adoption in 1867 of a statute which empowered [the] federal courts" to reexamine state court determinations, Hawk v. Olson, 326 U.S. 271, 274-75 (1945); see Darr v. Burford, 339 U.S. 200, 204 (1950), overruled on other grounds by Fay v. Noia, 372 U.S. 391 (1963). 
In exercising the power thus bestowed, the District Judge must take due account of the proceedings that are challenged by the application for a writ. All that has gone before is not to be ignored as irrelevant. But the prior State determination of a claim under the United States Constitution cannot foreclose consideration of such a claim, else the State court would have the final say which the Congress, by the Act of 1867, provided it should not have... . A State determination may help to define the claim urged in the application for the writ and may bear on the seriousness of the claim. That most claims are frivolous has an important bearing upon the procedure to be followed by a district judge. The prior State determination may guide his discretion in deciding upon the appropriate course to be followed in disposing of the application before him. The State record may serve to indicate the necessity of further pleadings or of a quick hearing to clear up an ambiguity, or the State record may show the claim to be frivolous or not within the competence of a federal court because solely dependent on State law. ${ }^{141}$

In light of the first italicized sentence, Justice Thomas' emblemization of the second italicized sentence is problematic.

In any event, this passage says nothing about deference. Rather, it simply directs that opportunistic use be made of, and polite respect paid to, the persuasive authority of a state court decision that happens to be directly on point. Indeed, the first italicized sentence, omitted by Justice Thomas, says rather clearly that giving state courts the final say on questions close enough that they reasonably might go either way is exactly what Congress did not permit federal habeas corpus courts to do.

But whatever one makes of this passage, it was only Justice Frankfurter's opening shot at the standard of review question. Justice Frankfurter then proceeded to set forth his own compendium of habeas corpus standards of review - to exactly the same effect as Justice Reed's: when faced with a prior "denial of relief by a federal court," the district court "may, [but] need not inquire anew" into the previously adjudicated factual and legal questions. 142 "When ... the issue turns on basic facts ... [ $[$ u]nless a vital flaw be found in the process of ascertaining such facts in the State court, the District Judge may accept their determination in the State proceeding and deny the application."143 But when the case "calls for interpretation of the legal significance" of the historical facts, "the District Judge must exercise his own judgment ....

141. Brown v. Allen, 344 U.S. at 500 (opinion of Frankfurter, J.) (emphasis added) (citation omitted); see Wright v. West, 112 S. Ct. 2492, 2488 (1992) (plurality opinion).

142. Brown v. Allen, 344 U.S. at 508 (opinion of Frankfurter, J.) (emphasis added); cf. id. at 497 (when the prior federal "adjudication" is merely the Supreme Court's denial of certiorari on direct review, that denial "in habeas corpus cases, as in others, ... cannot he interpreted as an 'expression of opinion on the merits" " and deserves no attention (quoting Sunal v. Large, 332 U.S. 174, 181 (1947))).

143. Id. at 506 (opinion of Frankfurter, J.) (emphasis added). 
[S]o-called mixed questions or the application of constitutional principles to the facts as found leave the duty of adjudication with the federal judge."144 Likewise, state adjudications of purely legal questions "cannot, under the habeas corpus statute, be accepted as binding. It is precisely these questions that the federal judge is commanded to decide."145

By way of example, Justice Frankfurter noted that in reviewing the state court determination of a denial of counsel claim, which then required case-by-case adjudication of the need for representation, the district judge should rely on the state courts for the historical facts. "But it is for the federal judge to assess on the basis of such historical facts the fundamental faimess of a conviction without counsel in the circumstances."146 In a passage Justice Thomas only half quotes, Frankfurter continued as follows: "Although there is no need for the federal judge, if he could, to shut his eyes to the State consideration of such issues, no binding weight is to be attached to the State determination.... The State court cannot have the last say when it, though on fair consideration . . . , may have misconceived a federal constitutional right."147

The Court designed these standards of review to "give weight to whatever may be relevant in the State proceedings," while "preserv[ing] the full implication of the requirement of Congress that the District Judge decide constitutional questions presented by a State prisoner even after his claims have been carefully considered by the State courts." 148 Congress "has seen fit to give this Court power to review errors of federal law in State determinations, and in addition to give to the lower federal courts power to inquire into federal claims, by way of habeas corpus."149 Through the writ, Congress thus has empowered "district courts to be the organ of the higher law rather than a Court of Appeals, or exclusively this Court."150

Again, exegesis is hardly warranted. Reading for sense suffices. The Supreme Court on direct review is an important "organ of the higher law," with "power to review errors of federal law in State determinations." But the Court's direct review responsibility is not "exclusive"; Congress has equally invested lower federal courts with "power to inquire into federal claims." In making that inquiry, prior federal adjudications may bind the decision, as may prior state court adjudications of fact. But, as would a Supreme Court Justice in the direct review cases Justice Frankfurter deems not merely illustrative but controlling, a federal district judge on habeas corpus review of a legal or mixed legal-factual question arising from the state courts "must exercise his

144. 1d. at 507 (emphasis added).

145. 1d. at 506 (emphasis added).

146. 1d. at 507-08 (emphasis added).

147. Id. at 508 (emphasis added).

148. Id. (emphasis added).

149. Id. at 508-09 (emphasis added).

150. Id. at 510 (emphasis added). 
own judgment," "independent" of the state court ruling. ${ }^{151}$ As such, relief is triggered by a "meritorious" federal constitutional claim-a "Federal constitutional right" that a state court so much as "misconceived." The fact that "claims have been carefully considered by the State courts" is no defense.

Were exegesis necessary, it would proceed from the very cases that Justice Frankfurter (and Justice Reed ${ }^{152}$ ) cited as illustrative-the famous set of decisions on direct review of state criminal judgments, beginning with Fiske v. Kansas ${ }^{153}$ and Norris $v$. Alabama, ${ }^{154}$ in which the Supreme Court developed "the so-called mixed question[]" doctrine of de novo review of dispositive issues in which factual and federal legal questions are "intertwined." 155 No one doubts that the review the Supreme Court affords in such cases is de novo. ${ }^{156}$ And the phrases with which the Court has described its de novo review throughout the decades proceeding and following Brown - for instance, "independent judgment," "exercise his own judgment," "duty of adjudication," "for the judge to assess," duty "to decide," and the like-are the very ones that Justice Frankfurter deployed in Brown. ${ }^{157}$

Justice Frankfurter's own classic statement of the mixed question doctrine in the direct appeal context, written just a few years before Brown, amply demonstrates the identity of the standards of review in the two contexts: issues of historical fact "are for conclusive determination by the State courts," but "a conclusion drawn from uncontroverted happenings, when that conclusion incorporates standards of conduct or criteria for judgment which in themselves are decisive of constitutional rights," is an "issue[] for this Court's adjudication"--"the very issue[] to review which this Court sits." 158

151. 1d. at 500-01.

152. See supra note 126 and accompanying text.

153. 274 U.S. 380 (1927).

154. 294 U.S. 587 (1935).

155. Brown v. Allen, 344 U.S. at 507 (opinion of Frankfurter, J.).

156. See, e.g., Arizona v. Fulminante, 111 S. Ct. 1246, 1252 (1991) (citing Miller v. Fenton, 474 U.S. 104, 110 (1985)); id. at 1261 (Rehnquist, C.J., dissenting on other grounds).

157. See, e.g., id. at 1252 (" 'independent federal determination' " (quoting Miller v. Fenton, 474 U.S. at 110)); Beck v. Ohio, 379 U.S. 89, 100 (1964) (Harlan, J., dissenting) ("the Court is free to draw its own inferences" and to exercise "independent judgment"); Spano v. New York, 360 U.S. 315, 316 (1959) ("the responsibility of making our own examination"); Norris v. Alabama, 294 U.S. 587, 589-90 (1935) ("duty to determine whether in truth a federal right has been denied"); see also Cedar Rapids Gas Light Co. v. Cedar Rapids, 223 U.S. 655, 668 (1912) (questions "open to reexamination" or "reexaminable"); Huntington v. Attrill, 146 U.S. 657, 684 (1892) ("[T]his court . . . must decide for itself. ...").

158. Watts v. Indiana, 338 U.S. 49, 50-51 (1949) (plurality opinion of Frankfurter,

J.) (emphasis added). Likewise Justice Reed, in Gallegos $v$. Nebraska, stated:

As state courts also are charged with applying constitutional standards of due process, in recognition of their superior opportunity to appraise conflicting testimony, we give deference to their conclusions on disputed and essential 
Primarily because of the broad range of claims it recognized as cognizable, Brown met intense scrutiny, not only in Congress and in the lower federal courts, but also in the writings of the Federal Jurisdiction titans of the 1950s and 1960s. Although these authorities disagreed about other aspects of Brown, they all, from the beginning, understood Brown to require de novo review of legal and mixed legal-factual questions. ${ }^{159}$ Indeed, even Virginia and its amici in Wright understood Brown as mandating de novo review and thus identified Brown as the decision they wanted the Court to overrule. ${ }^{160}$ So far as I know, Justice Thomas is the only observer to miss Brown's de novo review requirement.

Justice Thomas' analysis thus reveals nothing more than did Bator's, except for the passage of thirty additional years. Whatever may have come before 1953, as of that year it was the firm conviction of a unanimous Court that all constitutional claims were cognizable in

issues of what actually happened. . . . Its duty compels this Court, however, to decide for itself, on the facts that are undisputed, the constitutional validity of a judgment that denies claimed constitutional rights. ... [A] contrary rule would deny to the Federal Goverument ultimate authority to redress a violation of constitutional rights.

342 U.S. 55, 61 (1951) (emphasis added).

159. The following is a sampling of the legislative sources: 104 Cong. Rec. 19,338 (1958) (statement of Sen. Morse) (Under Brown, "it is a primary responsibility of the United States courts to pass upon the Federal constitutional aspects of State action, regardless of what the views of the State courts may be."); 114 Cong. Rec. 12,832 (1968) (statement of Sen. Tydings) ("The Supreme Court [in Brown] held specifically ... that a Federal district judge sitting in habeas corpus was authorized to grant a new hearing on the merits of a State prisoner's claim, even though the State court had litigated the issue on the merits adversely to the petitioner ...."); S. Rep. No. 226, 98th Cong., 1st Sess. 22 (1983) (recommending that Congress change "current law [under which] a Federal habeas corpus court ... is automatically required to make an independent determination of questions of law, and to re-apply the law to the facts, no matter how fully and fairly that has been done in the State proceedings."); 130 Cong. Rec. 1862 (1984) (statement of Sen. Baucus) (" $[\mathrm{M}] \mathrm{y}$ amendment would leave law on this issue as it now exists. That is, State prisoners would continue to he entitled to a full and independent review of their Federal claims in Federal courts."); Habeas Corpus Issues: Hearings before the Subcomm. on Civil and Constitutional Rights of the House Comm. on the Judiciary, 102d Cong., 1st Sess. 173 (1991) (statement of Andrew G. McBride, Assoc. Deputy Att'y Gen.) ("[U]nder present law, the legal determinations of the state courts are entitled to no weight at all in a federal habeas corpus proceeding.").

Among the academic sources are Hart \& Wechsler, 2d ed., supra note 38, at 1465 , 1486 ("whatever may have been the pre-1953 law, Brown v. Allen in 1953 squarely established the proposition that federal constitutional questions litigated in state criminal cases may be relitigated on habeas corpus"; Brown made state court adjudication "but a prelude to dispositive federal adjudication") and Bator, supra note 6 , at 444 \& n.4, 462, 474, 500 (Brown "explicitly enthroned the principle tbat all federal constitutional questions decided in state criminal cases may be redetermined on the merits of federal habeas corpus").

160. See Brief for the Petitioners at 9-10, 11-12 \& n.5, 14-15, 18-19 n.10, Wright v. West, 112 S. Ct. 2482 (1992) (No. 91-542); Brief for the United States as Amicus Curine at 12, 13, 22 \& n.10, Wright v. West, 112 S. Ct. 2482 (1992) (No. 91-542). 
habeas corpus and that each claim was due de novo federal review commensurate with the direct review it would have received had the Supreme Court granted certiorari to consider it.

d. The 1953-1985 Decisions. - Justice Thomas acknowledges that the third set of decisions on which his analysis rests-the habeas corpus cases between 1953 and 1985-"repeatedly reaffirmed Brown's teaching that mixed constitutional questions are 'open to review on collateral attack." "161 Once the clarity of Brown's holding is revealed, Justice Thomas' use of the post-Brown cases to prove that the Court never substituted a new analysis for the analysis in Brown cuts directly against his anti-Whiggian "too much, too recently" attack on the de novo review rule.

Moreover, as Justice O'Connor's opinion comprehensively reveals, lying just below the surface of Justice Thomas' citations of the 1950s1980 s decisions - that is, in their language and holdings-is a wealth of proof that the Court never wavered in its understanding of Brown as requiring de novo review of legal and mixed legal-factual questions. ${ }^{162}$ In its 1958 decision in Thomas v. Arizona,${ }^{163}$ for example, the Court indiscriminately cited direct appeal and habeas corpus precedents in support of "independent determination" of mixed questions on habeas corpus. ${ }^{164}$

In 1963, Townsend $v$. Sain ${ }^{165}$ carefully reconsidered the Court's existing doctrine on habeas corpus standards of review, concluding that, as under Brown, district judges should continue "defer[ring] to the state court's findings of fact," but "may not defer to its findings of law. It is the district judge's duty to apply the applicable federal law to the state court fact findings independently." 166 Dissenting on other grounds, Justice Harlan endorsed the same standard, ${ }^{167}$ stating approvingly in his opinion in a companion case that, " $[\mathrm{u}]$ nder . . . Brown, if a petitioner could show that the validity of a state decision to detain rested on a determination of a constitutional claim, and if he alleged that determination to be erroneous, the federal court had the right and the duty to

161. Wright v. West, $112 \mathrm{~S}$. Ct. at 2488 (plurality opinion) (quoting Cuyler v. Sullivan, 446 U.S. 335,342 (1980)).

162. See id. at 2495-96.

163. 356 U.S. 390 (1958).

164. 1d. at 393 (citing Malinski v. New York, 324 U.S. 401, 404 (1945) (direct review) and Brown v. Allen, 344 U.S. 443, 507 (1953) (opinion of Frankfurter, J.)); accord lrvin v. Dowd, 366 U.S. 717, 723 (1961); Cicenia v. Lagay, 357 U.S. 504, 508 (1958); Leyra v. Denno, 347 U.S. 556, 558-61 (1954); see also Spano v. New York, 360 U.S. 315, 316, 320, 321 \& n.2 (1959) (direct appeal case in which Court derived the de novo standard of review it applied-that the Court "cannot escape the responsibility for making our own examination of the record"--from its habeas corpus decisions in Brown and Leyra).

165. 372 U.S. 293 (1963).

166. 1d. at 318 (citing Brown v. Allen, 344 U.S. at 506 (opinion of Frankfurter, J.)).

167. See Townsend v. Sain, 372 U.S. at 326-27 (Stewart, J., dissenting, joined by Harlan, J.). 
satisfy itself of the correctness of the state decision."168

In 1972, through Justice Powell, the Court reiterated "the principle that each [habeas corpus petitioner] is entitled ... to a redetermination of his federal claims by a federal court." 169 Five years later, Justice Stewart commanded a bare majority of the Court in overturning the conviction of a self-confessed child murderer, based on the conclusion, reached using a de novo review standard derived both from Brown and from the Court's direct appeal decisions, that the defendant had not waived his right to counsel before confessing. ${ }^{170}$ The difficult facts of the case, the vehemence of the dissents (which also applied a de novo review rule ${ }^{171}$ ), and the close vote belie Justice Thomas' dismissal of the decision's de novo review language as dictum on the theory that the Iowa Supreme Court's conclusion that a valid waiver had occurred was "[un]reasonable." 172 It is likewise doubtful that the Court's sharply divided 1979 decision overturning a conviction because of discrimination in the selection of grand jury forepersons would have been the same had the Court not applied as it did a rule of "independent ... review by a federal court" on habeas corpus. ${ }^{173}$

Indeed, several years before the Court reaffirmed the point in Miller, then-Justice Rehnquist described as "long . . . established, as to those constitutional issues which may properly be raised under $\$ 2254$, that even a single federal judge may overturn the judgment of the highest court of a State insofar as it deals with the application of the United States Constitution or laws to the facts in question."174 Justice O'Connor's opinion in Wright quotes or cites two and one-half dozen Supreme Court decisions decided between 1954 and 1991 to like effect. ${ }^{175}$ Literally thousands of lower federal court decisions say the

168. Fay v. Noia, 372 U.S. 391, 460-61 (1963) (Harlan, J., dissenting), questioned on other grounds in Wainwright v. Sykes, 433 U.S. 72, 87-88 (1977), and overruled on other grounds by Coleman v. Thompson, 111 S. Ct. 2546, 2565 (1991). Compare id. (Brown requires review for "the correctness of the state decision" (emphasis added)) with Wright v. West, $112 \mathrm{~S}$. Ct. at 2487 (plurality opinion) (Brown "had no occasion to explore in detail whether a 'satisfactory' [state court] conclusion was one that the habeas court considered correct, as opposed to merely reasonable.").

169. Neil v. Biggers, 409 U.S. 188, 191 (1972). Justice Powell considered this principle to have been established by Congress' 1948 recodification of the 1867 Habeas Corpus Act, 14 Stat. 385 (1948).

170. See Brewer v. Williams, 430 U.S. 387, 404 (1977) (citing, e.g., United States v. Wade, 388 U.S. 218 (1967); Brown v. Allen, 344 U.S. 443 (1953); Miranda v. Arizona, 384 U.S. 436 (1966); Glasser v. United States, 315 U.S. 60 (1942)).

171. See Brewer v. Williams, 430 U.S. at 417-20 (Burger, C.J., dissenting); id. at 429 (White, J., dissenting); id. at 438 (Blackmun, J., dissenting).

172. Wright v. West, $112 \mathrm{~S}$. Ct. at 2488 (plurality opinion).

173. Rose v. Mitchell, 443 U.S. 545, 561 (1979); see id. at 580-82 (Powell, J., concurring in the judgment).

174. Sumner v. Mata, 449 U.S. 539, 543-44 (1981) (emphasis added).

175. See Wright v. West, 112 S. Ct. at 2493-97 (O'Connor, J., concurring in the judgment). 
same thing. 176

Thus, in 1985, when Justice O'Connor concluded for a unanimous Court in Miller that "an unbroken line of cases, coming to this Court both on direct appeal and on review of applications to lower federal courts for a writ of habeas corpus, forecloses the Court of Appeals' conclusion that the 'voluntariness' of a confession merits something less than independent federal consideration," and "nearly half a century of unwavering precedent weighs heavily against any suggestion that we now discard the settled rule in this area," 177 she was not, as Justice Thomas contends, inadvertently adopting a new rule under the impression that stare decisis bound her to an old one. If a conservative's "too much, too recently" charge is to be made with regard to the de novo review "reform," it will have to be the argument of a True Conservative-that forty years of de novo review of mixed questions (if only the habeas corpus cases are considered) or sixty years of the same thing (if the direct review cases also are considered) is too short a time to settle a rule.

e. Teague v. Lane and After. - What, then, of the "too short" flank to Justice Thomas' "too much, too recently" attack on de novo review? Have the Teague decisions unwittingly, or at least inexplicitly, unsettled the de novo review rule?

The simplest answer to these questions is the one Justice Thomas gave in the minuscule portion of his opinion that is not dictum-an answer in which at least seven Justices concurred. ${ }^{178}$ Unless it is waived by the state, Teague's nonretroactivity bar is treated by the Court as a threshold issue that habeas corpus courts must address before reviewing the merits of a petitioner's constitutional claim. ${ }^{179}$ Accordingly, before reaching the merits of West's Jackson claim, Justice Thomas first had to reject Virginia's claim that Teague barred relief, which he did, acknowledging that "[b]y its terms, Teague itself is not directly controlling, because West sought federal habeas relief under Jackson, which was decided a year before his conviction became final on direct review." 180 Then, without encountering any of the "logic[al]" difficulties that the Teague rule assertedly creates for de novo review, ${ }^{181}$ Justice Thomas simply and easily applied the Jackson rule de novo to the facts of the case.

Thus, as Justice Thomas demonstrated, the Teague doctrine does not neutralize the de novo review rule. The two doctrines are distinct and apply at separate stages of the adjudication of a habeas corpus

176. See supra note 107 .

177. Miller v. Fenton, 474 U.S. 104, 112, 115 (1985).

178. Justice Kennedy did not reach the Teague question, see Wright v. West, $112 \mathrm{~S}$. Ct. at 2499-500; see also id. at 2502-03 (Souter, J., concurring) (finding Teague bar different from one to which Justice Thomas alluded in discussing standards of review).

179. See, e.g., Collins v. Youngblood, 110 S. Ct. 2715, 2718 (1990).

180. Wright v. West, $112 \mathrm{~S}$. Ct. at 2491 (plurality opinion) (emphasis added).

181. 1d. at 2492. 
case. As Justice Souter recently pointed out, the Court's nonretroactivity decisions in essence establish a temporal choice-of-law principle for use by reviewing courts, namely, that as between different rules of law in existence earlier and later in a case's progress through the courts, the reviewing court must apply whatever rule of law the prior court was legally authorized to, and did, apply-new legal developments notwithstanding. ${ }^{182}$ The doctrine is utterly irrelevant to the standard the reviewing court should use in determining whether the prior court properly applied the "chosen" rule of law-the question at issue in Wright. ${ }^{183}$

Beneath the surface of the Teague cases, in their language and logic, lies the following answer to the question Wright did ask: Habeas corpus is designed to deter state courts from misapplying federal law in effect at the time the state courts acted. In words that resonate throughout the nonretroactivity decisions, "the threat of habeas serves as a necessary additional incentive for trial and appellate courts throughout the land to conduct their proceedings in a manner consistent with established constitutional standards." "184 Just as the writ's deterrent purpose is ill-served by reversing state courts when they properly apply existing law but fail to predict legal innovations that lie in the future, it is also ill-served by allowing state courts to misapply existing law as long as they do so "reasonably." For this reason, the Teague cases are replete with admonitions to federal habeas corpus courts to " 'determine that the conviction rests upon correct application of the law in effect at the time of the conviction" "; 185 to " "forc[e] [state] trial and appellate courts ... to toe the constitutional mark" " set by existing law; ${ }^{186}$ to determine that "trials and appeals conformed to then-existing constitutional standards"; 187 to require that " "[s]tate courts . . faithfully apply existing constitutional law" "; 188 and to "ensur[e]", as their

182. See James B. Beam Distilling Co. v. Georgia, 111 S. Ct. 2439, 2443 (1991) (plurality opinion).

183. Indeed, by assuring that the same rule of law applies in both the reviewed and the reviewing court, the nonretroactivity doctrine actually permits de novo "review." Otherwise, the later court would be "applying" a different rule for the first time, rather than "reviewing" the prior court's application of the same rule at an later time.

184. Teague v. Lane, 489 U.S. 288, 306 (1989) (plurality opinion) (quoting Desist v. United States, 394 U.S. 244, 262-63 (1969) (Harlan, J., dissenting) (emphasis added)).

185. Id., 489 U.S. at 306-07 (plurality opinion) (quoting Solem v. Stumes, 465 U.S. 638, 653 (Powell, J., concurring) (emphasis added)); cf. Wright v. West, 112 S. Ct. at 2487 (plurality opinion) (although Brown required habeas corpus courts to review state court decisions to see that they reached a " "satisfactory conclusion," " Court has never fully decided "whether a 'satisfactory' conclusion was one that the habeas court considered correct, as opposed to merely reasonable." (quoting Brown v. Allen, 344 U.S. 443, 463 (1953) (opinion of Reed, J.))).

186. Teague v. Lane, at 489 U.S. at 307 (quoting Solem v. Stumes, 465 U.S. at 653 (Powell, J., concurring)) (emphasis added).

187. Id. 310 (emphasis added).

188. Id. (quoting Engle v. Isaac, 456 U.S. 107, 128 (1982)) (emphasis added). 
"[f]oremost" task among the "underlying purposes of the habeas writ," that "state courts conduct criminal proceedings in accordance with the Constitution" 189 and that "state convictions comply with the federal law in existence at the time the conviction be[comes] final."190 This is hardly the language-or logic-of deference.

4. Summary of a Conservative's Argument, Analytical Shortcomings Aside. - Now stripped as well of the analytical problems that lie just below the surface of Justice Thomas' citations and quotations, the propositions his analysis supports are reduced to but two: First, at some point prior to or in Brown v. Allen, the Court required de novo review of all legal and mixed legal-factual issues arising in the adjudication of all constitutional claims cognizable on habeas corpus. Second, on the strength of Justice Thomas' "See generally" citation of Professor Bator's as yet unchallenged argnment, it would seem that Brown v. Allen is the earliest point at which the Court recognized the cognizability of the full range of constitutional claims.

These propositions do not make a case for the repeal of the de novo review rule. On just about any view of stare decisis, they make out precisely the opposite.

\section{Victory on Points: A Less Critical Analysis of the O'Connor and Kennedy Opinions}

The opposite conclusion, premised primarily on stare decisis, is the one towards which Justices O'Connor and Kennedy, with some analytic help from Justice Souter, proceed. Justice O'Connor attacks mainly Justice Thomas' "too much, too recently" critique, while Justice Kennedy attacks his "too short" argument.

1. A Pre-1953 Draw. - Point one of Justice O'Connor's nine-point memorandum challenges the Bator orthodoxy. Like Professor Bator's chief antagonist-Gary Peller ${ }^{191}$-Justice O'Connor argnes that what Bator describes as a progressively expanding range of cognizable habeas corpus claims is actually the historically expanding range of constitutional claims, all of which have long been litigable in habeas corpus. ${ }^{192}$

Based on a comprehensive analysis of the cases, Parts III and IV below conclude that the Bator-Peller debate ends in an uninformative draw, as neither thesis can explain important decisions that both theses must explain in order to convince. Of greater importance here is the fact, not mentioned by either Justice Thomas or Justice O'Connor, that the critical historical question in Wright was not "What claims were cog-

189. Saffle v. Parks, 494 U.S. 484, 488 (1990) (emphasis added).

190. Sawyer v. Smith, 110 S. Ct. 2822, 2827 (1990) (emphasis added).

191. See Gary Peller, $1 n$ Defense of Federal Habeas Corpus Relitigation, 16 Harv. C.R.-C.L. L. Rev. 579 (1982).

192. See Wright v. West, 112 S. Ct. 2482, 2493-94 (1992) (O'Connor, J., concurring in the result). 
nizable when?" but, rather, "What standard of review governed the claims that were cognizable?" Neither opinion sheds much historical light on that question. ${ }^{193}$

2. A 1953-1985 Win. - I find Justice O'Connor's points dealing with the 1953-1985 period convincing for the reasons discussed in section B, above: Justice O'Connor correctly takes Justice Thomas to task for mischaracterizing Justice Reed's discussion of the standard of review governing issues of fact as applying to the standard of review generally; ${ }^{194}$ for omitting Justice Frankfurter's statements giving federal habeas corpus judges the duty of independently adjudicating mixed questions; ${ }^{195}$ for ignoring thirty years of post-Brown pronouncements by the Court that federal habeas corpus courts " "may not defer to [a state court's] findings of law" "; 196 and for failing to see that "de novo review is not incompatible with the maxim that federal courts should 'give great weight to the considered conclusions of a coequal state judiciary,' just as they do to persuasive, well reasoned authority from district or circuit courts in other jurisdictions."197

3. Victory on Points on the Post-Teague Era. - Justice O'Connor's "Seventh" point is Justice Kennedy's single point-that Teague does not undermine a rule of de novo review of mixed questions. In a passage endorsed by Justice O'Connor, Justice Kennedy argues that most applications of previously settled constitutional standards turning on mixed questions of law and fact do not rely on "new rules," hence are not

193. Justice O'Connor's second, third, and ninth points also deal with the case and legislative history of habeas corpus and are covered in Parts III and IV.

194. Justice O'Connor points out that Justice Reed's " 'satisfactory conclusion' " language, which Justice Thomas quotes as establishing the Brown Court's standard of review of legal claims, comes from a portion of the Reed opinion labeled " 'Right to a Plenary Hearing" "that deals only with matters of fact. Wright v. West, $112 \mathrm{~S}$. Ct, at 2494 (O'Connor, J., concurring in the judgment) (discussing id. at 2487 (plurality opinion) (quoting Brown v. Allen, 344 U.S. 443, 463 (1953) (opinion of Reed, J.)) (citation omitted)). Justice Thomas replies that Justice Reed's phrase-a " "satisfactory conclusion" "-could not have referred to factual questions because "conclusion" is a term of art for legal determinations. Id. at $2488 \mathrm{n} .4$ (plurality opinion). Justice Thomas never explains how he can simultaneously chastise Justice O'Connor for her nontechnical reading of the generic term "conclusion" in the midst of a passage fraught with references to determinations of fact, yet himself read a sentence from the same passage in which the Brown Court twice refers, in terms, to " "a rehearing of the facts" " as if the sentence refers to the review of legal questions.

195. Wright v. West, $112 \mathrm{~S}$. Ct. at 2495 (O'Connor, J., concurring in the judgment) (quoting Brown v. Allen, 344 U.S. at 507, 508 (opinion of Frankfurter, J.)); see supra notes $153-158$ and accompanying text.

196. Wright v. West, $112 \mathrm{~S}$. Ct. at 2495 (O'Connor, J., concurring in the judgment) (quoting Townsend v. Sain, 372 U.S. 293, 318 (1963)); see supra notes 165-177 and accompanying text.

197. Wright v. West 112 S. Ct. at 2497 (O'Connor, J., concurring in the judgment) (quoting Miller v. Fenton, 474 U.S. 104, 112 (1985)); see supra notes 98, 125 and accompanying text. 
affected by Teague's nonretroactivity rule. ${ }^{198}$ Justice Kennedy thus clearly prescribes how Teague ought to work in mixed question cases. He does not, however, as clearly explain why.

Justice Souter's concurring opinion in Wright brings Justice Kennedy's nonretroactivity analysis into sharper focus. Whereas Justice Kennedy dangerously risks eliding the law-choosing and law-applying stages by subsuming " "the application of an old rule in a manner that was not dictated by precedent" "within his definition of a "new rule," 199 Justice Souter suggests instead that novelty arises not from the application of an old rule in a new setting, but rather from the use of a new and different rule that broadens the old rule to reach situations in which the old rule was not designed to apply. ${ }^{200}$

Justice Souter's focus on the level of specificity intended by the designers of the old rule helps explain Justice Kennedy's insight that many mixed question situations are poor candidates for a nonretroactivity bar. As Justice Kennedy notes, mixed question rules typically are designed to apply generally, in a range of factual situations. Accordingly, habeas corpus petitioners will rarely have the need-idiosyncrati-

198. Wright v. West, 112 S. Ct. at 2499 (Kennedy, J., concurring in the judgment). There are two ways to define a "new rule." One possibility in this regard is to define a rule as "new" if it gives criminal defendants more protection than the rule on which all reasonable judges could have agreed as of the date when the prisoner's direct appeal process ended, thus limiting habeas corpus petitioners to the rule of law that the most prosecution-prone "reasonable judge" would have identified as the law on the relevant date. See, e.g., Butler v. McKellar, 494 U.S. 407, 414 (1990). A second possibility is to give habeas corpus petitioners the benefit of the rule that the average, rather than the most prosecution-prone, "reasonable jurist" would have understood to be the law at the relevant time. See, e.g., Desist v. United States, 394 U.S. 244, 263-64 (1969) (Harlan, J., dissenting). The former rule discourages federal judges on habeas corpus from skating as close as they can to the Court's law-making function, but allows state judges to skate as close as they can to unconstitutionally prosecution-favoring rules. After vacillating between both these poles, see Teague v. Lane, 489 U.S. 288, 301 (1989) (plurality opinion) (using both definitions in same paragraph), the Supreme Court more recently had been tending towards the former, "all reasonable judges agree" formulation, see Butler v. McKellar, 494 U.S. at 414 . In Wright, however, Justices O'Connor and Kennedy moved towards the "average judge" approach. See Wright v. West, 112 S. Ct. at 2498-99 (Kennedy, J., concurring in the judgment); id. at 2497 (O'Connor, J., concurring in the judgment). Elsewhere, I advocate the "average judge" approach. See Liebman, supra note 44 , at 595-603.

199. Wright v. West, 112 S. Ct. at 2499 (Kennedy, J., concurring in the judgment) (quoting Stringer v. Black, 112 S. Ct. 1130, 1135 (1992)).

200. Although Justice Souter quotes the same passage from Stringer as does Justice Kennedy, id. at 2502 (Souter, J., concurring in the judgment), Justice Souter generally keeps his eye trained carefully on the "rule" to be applied, not on its application: "The crux of the analysis when Teague is invoked, then, is identification of the rule on which the claim for habeas relief depends." Id. at 2501. For Justice Souter, the determinative question, requiring "analytical care," is whether "a prisoner's invocation of a rule [is] at too high a level of generality"- too high, apparently, when compared to the level of generality intended by the framers of the rule. Put the other way around, the question is whether the old rule on which the petitioner relies "is specific enough to dictate the rule on which the conviction may be held to be unlawful." Id. 
cally presented to West by the hoary inference of theft from possession-to demand application of a rule that is more general than the one the framers of the old rule intended. ${ }^{201}$

Justice Souter thus managed to maintain the distinction between the law-choosing and law-applying stages of habeas corpus adjudication even while wielding an extremely broad definition of new rules. ${ }^{202}$ That Justice Souter could press the law-choosing Teague rule to the hilt without wounding the law-applying de novo review rule is the most convincing proof of all that the two doctrines are distinct.

All this said, the critical fact here is that the opinions of Justices O'Connor, Kennedy and (indirectly) Souter repel Justice Thomas' "too short" assault on the de novo review rule: nonretroactivity rules and standards of review are distinct, and the Court's use of a reasonableness rule in the former context does not dictate a similarly deferential standard in the latter context.

Arguing to a draw on the pre-1953 point, Justices O'Connor and Kennedy, with some help from Justice Souter, win all the important post-1953 points, and thus the debate as a whole. Indeed, they do so on Justice Thomas' own anti-Whiggian terms, assuming only that a forty-year-old rule deserves stare decisis respect.

\section{Is to Ought: The Search for an Affirmative Case}

The problem with the O'Connor-Kennedy argument is that it presents no affirmative case for preserving the de novo review rule apart from the rule's venerable age. The argument thus may not be sufficient to win the final battle that Justice Thomas' plurality opinion heralds. After all, these are anti-conservative, as well as anti-Whiggian, judicial times in which we live.

Can an affirmative case be made? Justice O'Connor's opinion in Wright tangentially suggests two possibilities. Her claim that Congress since 1966 has refused to amend the habeas corpus statute to incorporate a deference rule ${ }^{203}$ suggests that Congress may have at least implicitly adopted a de novo rule prior to that time. But apart from Justice O'Connor's brief reliance on an argument of this sort in her 1985 opinion for the Court in Miller v. Fenton, ${ }^{204}$ neither her nor the Court's views on the statutory status of de novo review are clear.

A second possibility is suggested by Justice O'Connor's references to the Court's frequent recourse, in its habeas corpus decisions, to the

201. For Justice Souter, the problem in Wright was that West could not secure relief unless he could turn Jackson's case-by-case rule analyzing the impact of all the evidence into a categorical rule forbidding reliance on a particular type of evidence, namely, the inference of theft from recent possession of stolen goods. See id. at 2502-03 (Souter, J., concurring in the judgment).

202. See id. at 2501.

203. See id. at 2498 (O'Connor, J., concurring in the judgment).

204. See Miller v. Fenton, 474 U.S. 104, 111-12 (1985). 
Court's de novo review rule on direct appeal. ${ }^{205}$ Might Justice O'Connor find, as I do, an affirmative justification for de novo habeas corpus review in its parity with, and federal-judiciary-wide surrogacy, for, direct Supreme Court review?

From Justice O'Connor's perspective, the difficulty with this possibility is her repeated rejection-which Justice Thomas endorses and extends in Wright-of the writ's use " " "as a substitute for direct review." "206 But just as the alleged disparities between direct and habeas corpus review that Justice Thomas identifies actually confirm the two procedures' parity or surrogacy, so also can respectable appellate principles explain the apparent disparity Justice O'Connor identifies.

Justice Thomas lists three "differences" between direct and habeas corpus review. ${ }^{207}$ The first, the constitutional requirement of counsel on direct review, but not in habeas corpus, is not a difference at all but another point of parity. Habeas corpus has never been understood as a surrogate for direct appeal to state supreme courts, which are constitutionally obliged to provide counsel to indigent criminal defendants, ${ }^{208}$ but rather for direct appeal to the United States Supreme Court, whicb has never constitutionally obligated itself to provide counsel. ${ }^{209}$ Indeed, the statutory right to counsel on habeas corpus-which becomes mandatory only if a hearing is ordered ${ }^{210}$-is a near-perfect replica of the Supreme Court's practice in regard to providing counsel to indigent certiorari petitioners.

As discussed above, the second difference-the nonretroactivity bar in babeas corpus proceedings-actually derives its chief justification from its capacity to achieve parity between direct and habeas corpus review and to render the latter a fair surrogate for the former, by limiting habeas corpus petitioners to the same rule of law as applied in their direct appeal certiorari proceedings. ${ }^{211}$

The third difference, the Stone v. Powell ${ }^{212}$ bar to habeas corpus consideration of exclusionary rule claims, is actually a difference, but one that the Court achieved only by denigrating the exclusionary rule to a less-than-constitutional, "merely prophylactic" status. ${ }^{213}$ As

205. See Wright v. West, 112 S. Ct. at $2495-96$ (O'Connor, J., concurring in the judgment).

206. Teague v. Lane, 489 U.S. 288, 306 (1989) (plurality opinion of O'Connor, J.) (quoting Mackey v. United States, 401 U.S. 667, 682-83 (1971) (Harlan, J., concurring in judgment in part and dissenting in part)), quoted in Wright v. West, $112 \mathrm{~S}$. Ct. at 2490 (plurality opinion).

207. See Wright v. West, 112 S. Ct. at 2490-91 (plurality opinion).

208. See Douglas v. California, 372 U.S. 353, 355-58 (1963).

209. See Ross v. Moffitt, 417 U.S. 600 (1974).

210. See Rule $8(c)$ of the Rules Governing $\$ 2254$ Cases.

211. See supra notes $42-44$ and accompanying text.

212. 428 U.S. 465 (1976).

213. See, e.g., Kimmelman v. Morrison, 477 U.S. 365, 379 n.4 (1986). 
noted, habeas corpus is a surrogate for Supreme Court review only of state-prisoner claims sufficiently central to national legal policy to justify federal judicial review as of right. ${ }^{214}$ By "de-constitutionalizing" the exclusionary rule-in an opinion premised on distinctions between the "personal" rights the Constitution directly affords criminal defendants and the generalized societal interests the exclusionary rule protects ${ }^{215}$ - the Supreme Court placed exclusionary rule claims, like most other nonconstitutional federal law claims, ${ }^{216}$ outside the category of nationally important claims as to which federal review as of right is maintained. ${ }^{217}$

Before examining the support offered for Justice O'Connor's dissenting argument in the recent case of Keeney $v$. Tamayo-Reyes ${ }^{218}$ that "[ $\mathrm{h}]$ abeas corpus is not an appellate proceeding, but rather an original civil action," 19 consider some of the ways in which-as Justice O'Connor is careful to acknowledge-habeas corpus proceedings do not resemble original civil actions. First, habeas corpus actions are affected by prior judicial proceedings far too frequently to qualify as truly separate or "original" actions. As Justice O'Connor notes, habeas corpus petitioners face a "peculiar set of hurdles" that are unknown to litigants pursuing "original civil action[s] in a federal court," including that the habeas corpus petitioner "must, in general, exhaust available state remedies, ... . avoid procedural default [of the claim in the state courts], . . . and not seek retroactive application of a new rule of law."220 Also unlike other civil litigants, ${ }^{221}$ habeas corpus petitioners do not have the right to a hearing on all of the controverted factual allegations that make out a federal cause of action. Instead, federal courts are required to "defer[] to state court findings of fact where the federal district judge [is] satisfied that the state court ha[s] fairly considered the issues and the evidence and . . . reached a satisfactory result."222 Furthermore, the one set of effects that prior proceedings

214. See supra notes $40-41$ and accompanying text.

215. See Stone v. Powell, 428 U.S. at 494 n.37.

216. See 1 Liebman, supra note $24, \S 8.4 \&$ nn.24-26.

217. See Kimmelman v. Morrison, 477 U.S. at 379 n.4; Rose v. Mitchell, 443 U.S. 545, 560 (1979). The exclusionary rule thus does not fully implicate one of the two liberty interests that, together, motivate the policy favoring federal review as of right. See supra note 41. As currently understood by the Court, a Fourth Amendment violation offends the movant's rights only at the time of the unlawful search or seizure, but not when the procedure's fruits are introduced in evidence. Consequently, the exclusionary rule protects the movant's liberty interest only in securing person and property from unlawful government intrusion and not her liberty interest in immunity from conviction and incarceration in violation of federal law.

218. 112 S. Ct. 1715 (1992).

219. Id. at 1722 (O'Connor, J., dissenting) (citation omitted).

220. Id. (citations omitted).

221. See Fed. R. Civ. P. 12(b)(6); Fed. R. Civ. P. 56.

222. Keeney v. Tamayo-Reyes, 112 S. Ct. at 1723 (discussing 28 U.S.C. $§ 2254$ (d) (1992)). 
typically do have on "original civil action[s]," namely, res judicata and collateral estoppel, does not apply in habeas corpus proceedings. ${ }^{223}$ Notice finally that each of these "differe[nces] from ordinary civil litigation"224 - the exbaustion of prior remedies requirement, the adequate and independent state grounds (i.e., procedural default) doctrine, the limitation to law available at the time of direct appeal, the dichotomy between de novo legal but only "clearly erroneous" factual review, the absence of a claims- and an issue-preclusion bar-is easily explained by, and indeed is a classic indicium of, an appellate relationship.

If the appellate analogy explains these myriad attributes of habeas corpus review in a way the "original civil action" analogy cannot, then what is left to commend the latter analogy? Justice O'Connor gives two answers: Ex parte Tom Tong's ${ }^{225} 1883$ characterization of habeas corpus as a " 'new suit' " separate from the criminal prosecution, and the statutory authorization of evidence-taking procedures in habeas corpus courts. ${ }^{226}$

As will be seen in Part IV, arrayed against Tom Tong's 100-year-old "new suit" description of habeas corpus are numerous Supreme Court holdings from the preceding century that the filing of a habeas corpus petition initiates an "appellate" procedure-one court's review of another-over which the Court could (and repeatedly did) take jurisdiction without transgressing the strict constitutional limitations on its jurisdiction to hear "original civil actions."227 Tom Tong is the exception that proves the rule. It was one of the few habeas corpus cases brought directly to the Supreme Court in which the "appellate" characterization was inaccurate, because the petitioner's detention had no judicial authorization and had occurred at the behest of local law enforcement officials acting on their own. ${ }^{228}$

Nor is Tom Tong's distancing of habeas corpus from the "criminal prosecution" inconsistent with the appellate analogy drawn here. It is in the very nature of the "limited" federal appeal available both on certiorari and habeas corpus that the principal concern of the "criminal prosecution"- the defendant's guilt or innocence-is not at issue. ${ }^{229}$

The case for the "original civil action" analogy thus comes down to the evidence-taking procedures that the habeas corpus statute autho-

223. See id. at 1723 ("Habeas has always differed from ordinary civil litigation, however, in one important respect: The doctrine of res judicata has never been thought to apply. A state prisoner is not precluded from raising a federal claim on habeas that has already been rejected by the state courts.").

224. Id. at 1723 .

225. 108 U.S. 556 (1883).

226. Keeney v. Tamayo-Reyes, 112 S. Ct. at 1722 (quoting Ex parte Tom Tong 108

U.S. at 559-60; citing 28 U.S.C. $\$ \S 2242,2246,2247,2254$ (d)).

227. See infra note 349 and accompanying text.

228. See Ex parte Tom Tong, 108 U.S. at 558-59.

229. See, e.g., Moore v. Dempsey, 261 U.S. 86, 87-88 (1923) (Holmes, J.); 1

Liebman, supra note $24, \S 2.2 \&$ nn.42-46 (Main Volume and 1992 Supp.). 
rizes "reviewing" federal courts to undertake in the one or two percent of cases in which the facts are controverted and the state court factfindings are not controlling. ${ }^{230}$ Even if this evidence-taking capacity did establish a discrepancy between habeas corpus and appellate proceedings, one still might ask whether that single discrepancy would overcome the more numerous and important ways in which the writ is incompatible with an original action and functions just like an appeal. But, as discussed earlier, the district court's authorization to hear evidence does not create a discrepancy between direct Supreme Court and habeas corpus review. Rather, both modes of federal review of state court determinations adhere to the same pragmatic appellate principlenamely, a preference for allocating necessary relitigation of evidentiary questions to the court with evidence-taking capacities nearest the reviewing court. ${ }^{231}$ On direct appeal, this principle requires a remand to the state supreme court to direct the case to the appropriate evidencetaking forum. On habeas corpus, this requires the district court itself to undertake the necessary evidentiary proceedings.

In the end, the sometime preference of Justice Thomas, Justice O'Connor, and the Court generally for an "original civil action" analogy, and their resistance to an appellate analogy, stand firmly on the proposition that habeas corpus is neither a surrogate for a criminal trial nor a substitute for direct appeal within the state system.

This same proposition, however, constrains the Supreme Court's direct review of state criminal cases on certiorari, not because the Court's certiorari review is discretionary, but because the Court's jurisdiction is constitutionally and statutorily limited to a small subset of the legal issues that arise in state criminal proceedings. The proposition thus supplies no basis for distinguishing between direct review in the Supreme Court when certiorari is granted and habeas corpus review in the district courts after certiorari is denied.

Two forms of reasoning from "what is" to "what ought to be" support retaining de novo review of state court determinations of constitutional law in criminal cases. The first is the traditional principle of stare decisis. The second is the impulse to explain the uncanny parallels between direct review on writ of certiorari in the Supreme Court and postconviction review on writ of habeas corpus in the district courts as more than accidental, as rather the desire of some institution, be it Congress, the Court, or the federal judiciary as a whole, for parity between direct and habeas corpus review-or even, carrying the impulse a bit further, for using lower federal court adjudication as a surrogate

230. See supra note 45 and accompanying text. Justice $O^{\prime}$ Connor also refers to the statutory pleading requirements, Keeney v. Tamayo-Reyes, $112 \mathrm{~S}$. Ct. at 1722 (O'Connor, J., dissenting), but the differences between pleading an original action and presenting an appeal are sufficiently tenuous that these requirements need not detain me.

231. See supra notes $20,36,48$ and accompanying text. 
for the Supreme Court's unifying, concluding, and national-law-protecting functions. This Part has validated the first rationale, and it alone may be sufficient to warrant leaving the writ in its current, fortyyear-old form. Still, the power of the stare decisis rationale may be enhanced, and the validity of the parity/surrogacy-by-design rationale established, by a better understanding of the pre-1953 history of habeas corpus. It is to that history that I now turn.

\section{Two Theses and Two Tests of the Historical Scope of Habeas Corpus Review in the United States}

\section{A. Two Theses}

Over the last thirty years, judicial and academic analyses of the history of habeas corpus in the United States have focused on two theories that provide a useful starting point for my own analysis of the writ's history. ${ }^{232}$ Both theories took shape in 1963, one in Professor Bator's article mentioned above, ${ }^{233}$ the other in Justice Brennan's famous, but since eroded and recently overruled, decision in Fay v. Noia. ${ }^{234}$ Subjected to scathing academic attack at the time, ${ }^{235}$ Justice Brennan's thesis waited two decades for a thorough academic defense, which was finally advanced in a 1982 article by Gary Peller. ${ }^{236}$

1. The Bator Thesis. - Despite being dismissed in a footnote by the Fay v. Noia majority, ${ }^{237}$ Professor Bator's article now dominates habeas corpus jurisprudence and scholarship. ${ }^{238}$ According to Professor Bator, the number of claims cognizable in habeas corpus expanded in five stages from 1789 to 1953 . The 1789 Judiciary Act gave federal courts the power to grant writs on behalf of federal prisoners "for the purpose of an inquiry into the cause of commitment."239 Following English common law practice, the Supreme Court took this phrase to mean something like probable cause to detain the petitioner, which, in turn, meant that proof of conviction by a court of competent jurisdiction ended the inquiry because it provided sufficient evidence of probable cause to detain. ${ }^{240}$ Logically, a competent grand jury's indictment or even a competent magistrate's arrest warrant following a probable cause finding deserved the same preclusive effect. As understood by

232. Some of the major historical works are collected in 1 Liebman, supra note 24 , $\S 2.2 \mathrm{n} .16$.

233. See Bator, supra note 6.

234. 372 U.S. 391 (1963), questioned in Wainwright v. Sykes, 433 U.S. 72, 87-88 (1977), and overruled by Coleman v. Thompson, 111 S. Ct. 2546, 2565 (1991).

235. See, e.g., Lewis Mayers, The Habeas Corpus Act of 1867: The Supreme Court as Legal Historian, 33 U. Chi. L. Rev. 31, 58 (1965); Dallin H. Oakes, Legal History in the High Court-Habeas Corpus, 64 Mich. L. Rev. 451, 459-68 (1966).

236. See Peller, supra note 191 .

237. See Fay v. Noia, 372 U.S. at 421-22 n.30.

238. See supra notes $74-75,105$ and accompanying text.

239. Act of Sept. 24,1789 , ch. $20, \S 14,1$ Stat. 73, 81-82.

240. See Bator, supra note 6 , at 466 . 
Bator, therefore, the writ's transformation from a method in England of reviewing pretrial executive detention to a method in this country of reviewing judicially sanctioned pre- and post-trial incarceration left nothing for review save the competency-that is, the subject matter and personal jurisdiction-of the detaining tribunal. ${ }^{241}$

According to Professor Bator, this state of affairs continued until the 1870s, when Ex parte Lange ${ }^{242}$ and Ex parte Siebold ${ }^{243}$ made the writ available to remedy unconstitutional sentences and incarceration under unconstitutional penal laws. ${ }^{244}$ As Bator acknowledged, the logic behind this halting step was unclear. ${ }^{245}$ There was no real difference between a court's enforcement of a penal statute or its imposition of a sentence lacking in constitutional authority and, say, a judge's convicting a defendant himself, without the constitutional authority that only a jury could confer. Yet, on Professor Bator's understanding, the Court extended the writ only to unconstitutional statutes and sentences and not, for example, to denials of constitutionally required trial by jury. ${ }^{246}$

Tied as it is to the 1789 Act's "cause of commitment" language and common law lineage, Professor Bator's narrow interpretation of the antebellum writ would seem to retain little relevance after Congress' 1867 extension of habeas corpus to a federal-or stateprisoner's detention "in violation of the constitution, or of any treaty or law of the United States"247 and its 1885 conferral on the Supreme Court of jurisdiction under the 1867 Act. ${ }^{248}$ According to Bator, however, Congress' apparent expansion of jurisdiction had almost no effect because of the Court's adoption, apparently by fiat, 249 of a Catch 22 preclusion doctrine in a series of cases beginning in 1886 with Ex parte

241. See id. at 471-74; see also Paul M. Bator et al., Hart \& Wechsler's The Federal Courts and the Federal System 1427-28, 1465-66 (3d ed. 1988) [hereinafter Hart \& Weschler, 3d ed.]. Because prior to the $1830 \mathrm{~s}$, conviction of a crime in England generally ended incarceration in favor of noncustodial penalties such as execution, branding, or banishment, Bator is correct to describe early English habeas corpus practice as largely a pretrial affair. He is wrong to suggest that this was the writ's only use, however. In the rare instances in which incarceration was used as a punishmentfor example, in contempt cases-the writ served in England to review post-trial, judicially sanctioned incarceration. See, e.g., Bushell's Case, 124 Eng. Rep. 1006 (C.P. 1670); Ex parte Kearney, 20 U.S. (7 Wheat.) 38, 41-42 (1822) (Story, J.); Ex parte Bollman, 8 U.S. (4 Cranch) 74, 91-92, 100 (1807) (Marshall, C.J.).

242. 85 U.S. (18 Wall.) 163,166 (1873).

243. 100 U.S. 371, 376-77 (1879).

244. See Bator, supra note 6 , at $467-68$.

245. See id. at $471-72$.

246. See id. at $472-73$.

247. Act of Feb. 5, 1867, ch. 28, § 1, 14 Stat. 385.

248. See Act of Mar. 3, 1885, ch. 353, 23 Stat. 437. For a discussion of Congress' 1867 conferral, 1868 withdrawal, and 1885 restoration of the Court's jurisdiction under the 1887 Act, and of the impact of the unified codification of the 1789 and 1867 haheas corpus provisions in the Revised Statutes of 1874, see infra notes 376, 382-383, 390-393, 415-420 and accompanying text.

249. See Bator, supra note 6, at 478-80; Anthony G. Amsterdam, Criminal 
Royall. ${ }^{250}$ As described by Bator, Royall's so-called "exhaustion of state remedies" doctrine required state prisoners to challenge unconstitutional incarceration in state trial and appellate courts before alleging it on habeas corpus, but then made the state courts' resolution of the issues res judicata in subsequent habeas corpus proceedings unless the detaining court lacked jurisdiction, had convicted the petitioner under an unconstitutional statute, or had imposed an unconstitutional sentence. ${ }^{251}$

From this low point in the writ's history, according to Professor Bator, both a modest and a giant step were needed to bring habeas corpus to its high point in the aftermath of Brown. Taking the penultimate step, Frank v. Mangum ${ }^{252}$ and Moore v. Dempsey ${ }^{253}$ limited Royall's res judicata doctrine by allowing habeas corpus resolution of federal claims as to which "full and fair" corrective process was unavailable in the state courts. ${ }^{254}$ Commencing the last step, a series of Supreme Court decisions in the 1930s and 1940s expanded the range of constitutional claims understood as attacks on the convicting court's jurisdiction. ${ }^{255}$ Then, exploding the "no jurisdiction" myth, Brown completed the step, making all constitutional claims fair game on habeas corpus review. ${ }^{256}$

2. The Brennan-Peller Thesis. - By contrast, Justice Brennan and Professor Peller argue that habeas corpus had always been a forum for providing specified classes of prisoners with review of the legality of their detention under fundamental national law. ${ }^{257}$ This result occurred naturally under the "cause of commitment" language, which emerged from proto-due process notions stretching back to the Magna Carta. The 1867 act simply expanded the range of fundamental claims from those drawing upon due process notions to constitutional claims of all sorts. ${ }^{258}$

Recognizing that the Court's relatively rare grants of review and relief represent too small a proportion of its habeas corpus jurisprudence to make the above description complete, Justice Brennan and Professor Peller identify three limitations that frequently led the Court to deny the writ. First, because Article 1 III withheld original jurisdiction

Prosecutions Affecting Federally Guaranteed Civil Rights: Federal Removal and Habeas Corpus Jurisdiction to Abort State Court Trial, 113 U. Pa. L. Rev. 793, 883-92 (1965). 250. 117 U.S. 241 (1886).

251. See Bator, supra note 6 , at $478-83$.

252. 237 U.S. 309,331 (1915).

253. 261 U.S. 86,91 (1923).

254. See Bator, supra note 6 , at $486-87,489$.

255. See id. at 493-99 (discussing, e.g., Johnson v. Zerbst, 304 U.S. 458 (1938)).

256. See id. at 500 .

257. See Fay v. Noia, 372 U.S. 391, 401-02, 409-10, 418 (1963), questioned on other grounds in Wainwright v. Sykes, 433 U.S. 72, 87-88 (1977), and overruled on other grounds by Coleman v. Thompson, $111 \mathrm{~S}$. Ct. 2546, 2565 (1991).

258. See id. at 404-10; Peller, supra note 191, at 618-22, 629-30. 
over criminal and habeas corpus cases from the Supreme Court, and Congress withheld appellate jurisdiction in criminal cases, ${ }^{259}$ the Court felt constrained from using habeas corpus as a substitute for the criminal jurisdiction it so clearly had been denied. Thus, the theory goes, only the lower federal courts, with unlimited "original" jurisdiction, could exercise unlimited jurisdiction to issue the writ. ${ }^{260}$

Second, until the incorporation movement of the 1940s-1960s, the constitutional due process right that was fully enforceable in habeas corpus meant no more than a "competent" forum-one with subject matter and personal jurisdiction-proceeding according to the applicable positive or common law and (a later requirement) the right to notice and a chance to be heard. ${ }^{261}$ Thus, what Professor Bator treats as the writ's limitation was instead the outer reach of contemporary interpretations of the Due Process Clause and the Constitution.

Finally, Justice Brennan and Professor Peller interpret many of the Court's decisions as relief-delaying, but not, as Professor Bator would have it, relief-denying applications of the exhaustion doctrine. In Justice Brennan's view, the exhaustion doctrine was simply an exercise in good federalist manners-letting the state courts go first and forbearing any federal interference unless and until the state courts failed to enforce the Constitution. ${ }^{262}$ In Professor Peller's more ingenious view, the exhaustion doctrine was designed to circumvent the longstanding (but since abandoned) limitation of habeas corpus remedies to letting the criminal go free, in contrast to direct appeal remedies, which permitted remand for retrial. ${ }^{263}$

3. Both Wrong: The Two Theses Compared. - The most common criticism of Professor Bator's theory is that its preclusive understanding of the exhaustion doctrine ignores the Court's repeated statements that state court review need only occur "in the first instance," or "in advance of" habeas corpus review-as if a "second instance" of federal

259. See U.S. Const. art. III, § 2; see also Ex parte Parks, 93 U.S. 18, 22-23 (1876); Ex parte Kearney, 20 U.S. (7 Wheat.) 38, 42 (1822); Ex parte Bollman, 8 U.S. (4 Cranch) 74,94 (1807). Congress did not permit appeals by federal prisoners, the only prisoners with access to habeas corpus under the I789 Act, until 1891. See infra note 453 and accompanying text.

260. See Fay v. Noia, 372 U.S. at $391,429-30$; Peller, supra note 191 , at $612-13$ (discussing In re McDonald, 16 F. Cas. 23 (D.C.E.D. Mo. I861) (No. 8,751)); see also Stephen A. Saltzburg, Habeas Corpus: The Supreme Court and the Congress, 44 Ohio St. L.J. 367, 370-72 (I983).

261. See Wright v. West, 112 S. Ct. 2482, 2493-94 (1992) (O'Connor, J., concurring in the judgment); Fay v. Noia, 372 U.S. at 412-14; Peller, supra note 191, at 628-29 (discussing, e.g., Kennard v. Louisiana ex rel. Morgan, 92 U.S. 480 (1875)).

262. See Fay v. Noia, 372 U.S. at 418-22.

263. See Peller, supra note I9I, at 640-41 (discussing, e.g., In re Frederich, 149 U.S. 70, 77-78 (1893)). See generally 1 Liebman, supra note $24, \S 8.5$ (discussing modern conditional habeas corpus remedy under which the prisoner is actually released only if he is not retried within a specified time period). 
review was to occur in the wake of state court review. ${ }^{264}$

Also telling are Professor Bator's difficulties explaining some landmark habeas corpus cases. Consider, for example, the Court's celebrated equal protection decision in Yick Wo v. Hopkins. ${ }^{265}$ In Yick Wo, the Court adjudicated the claims of two Chinese laundry operators that San Francisco officials had discriminatorily enforced the city's admittedly constitutional ordinance that made it a crime to operate a laundry in a wooden building. ${ }^{266}$ One of the applicants reached the Court on writ of error from the California Supreme Court; the other on appeal from a federal habeas corpus ruling. ${ }^{267}$ Yick Wo thus presented the Court with the perfect opportunity to prove Bator's thesis-that, although direct appeal was open to all constitutional attacks on state court convictions, habeas corpus was open only to attacks on jurisdiction, statutes, and sentences. The Court, of course, did no such thing, instead granting relief to both petitioners without any suggestion that their different procedural postures affected the cognizability of their identical claims. ${ }^{268}$

Similarly, in a number of other turn-of-the-century cases, the Court undeniably decided-although it denied-constitutional claims that were not premised on the detaining court's lack of jurisdiction or application of an unconstitutional statute or sentence. ${ }^{269}$ The best Professor Bator could do was to explain these cases as harmless curiosities-momentary lapses of the Court's concentration in cases in which relief, in any event, was denied. 270

Consider next the 1915 case of Frank $v$. Mangum ${ }^{271}$ and the 1923 case of Moore v. Dempsey. ${ }^{272}$ In both, the petitioners claimed they were convicted at a trial at which the judge and jury were under the sway of angry mobs. ${ }^{273}$ The Court denied Frank relief, but directed the district court to hear the Moore petitioners' claims. According to Professor Bator, at the time of Frank and Moore, habeas corpus relief was available

264. E.g., Urquhart v. Brown, 205 U.S. 179, 181-82 (1907); Cook v. Hart, 146 U.S. 183, 195 (1892); see, e.g., Peller, supra note 191, at 640; Saltzburg, supra note 260, at 377; Wechsler, Habeas Corpus and the Supreme Court, 59 U. Colo. L. Rev. 167, 174-75 (1988).

265. 118 U.S. 356 (1886).

266. See id. at 368 .

267. See id. at 356.

268. See id. at 365-66 (determinative issue in both cases was "whether the plaintiff ... has been denied a right in violation of the Constitution, laws, or treaties of the United States").

269. See, e.g., Felts v. Murphy, 201 U.S. 123, 129 (1906); Davis v. Burke, 179 U.S. 399, 403-04 (1900); Bergemann v. Backer, 157 U.S. 655, 656-68 (1895); ln re Converse, 137 U.S. 624, 631 (1891); In re Duncan, 139 U.S. 449, 454-61 (1891); Crowley v. Christensen, 137 U.S. 86, 92-94 (1890).

270. See Bator, supra note 6 , at 480 .

271. 237 U.S. 309 (1915).

272. 261 U.S. 86 (1923).

273. See Moore v. Dempsey, 261 U.S. at 88-89; Frank v. Mangum, 237 U.S. at 324. 
only on constitutional claims that the state courts had not given the prisoners a fair opportunity to litigate. Yet, because the prisoners in both cases had the same opportunity to litigate-trials allegedly dominated by mobs, followed by seemingly regular proceedings on motion for a new trial and appeal274 - the Bator theory has no satisfactory explanation for the divergent outcomes in the two cases, just eight years apart.

The Brennan-Peller explanations for the Court's frequent denials of habeas corpus review and relief encounter parallel difficulties. First, Justice Brennan and Professor Peller both assume that, because the limitation on habeas corpus review imposed by the absence of federalprisoner direct appeals emanated from limits on the Court's original jurisdiction and not on the writ itself, the limitation did not affect the lower courts' habeas corpus jurisdiction. ${ }^{275}$ But the lower federal courts need a congressional go-ahead to exercise either appellate or original jurisdiction. ${ }^{276}$ If Congress' denial of federal-prisoner direct appeals narrowed the Supreme Court's appellate jurisdiction to issue the writ, it also should have narrowed the lower federal courts' original and appellate jurisdiction to do the same $\mathrm{e}^{277}$ - especially given the use of the same words of the same section of the 1789 Act to grant habeas corpus power to the Supreme Court and the lower federal courts. ${ }^{278}$

Indeed, if Congress' treatment of criminal appeals dictated the habeas corpus jurisdiction of either the Supreme Court or the lower federal courts, then neither level of the judiciary should have exercised any habeas corpus jurisdiction, because Congress forbade both to hear criminal appeals of any sort. Each time the Court was presented with this argument, however, the Court rejected it, ${ }^{279}$ apparently on the theory that section 14 was itself a constitutionally sufficient grant of appellate authority for both the Court and the lower federal courts. ${ }^{280}$

274. See Moore v. Dempsey, 261 U.S. at 89; id. at 97-98 (McReynolds, J., dissenting); Frank v. Mangum, 237 U.S. at 312-17.

275. See Fay v. Noia, 372 U.S. $391,429-31$ (1963), questioned on other grounds in Wainwright v. Sykes, 433 U.S. 72, 87-88 (1977), and overruled on other grounds by Coleman v. Thompson, 111 S. Ct. 2546, 2565 (1991); Peller, supra note 191, at 610-16.

276. See, e.g., Ex parte Cabrera, 4 F. Cas. 964, 965 (C.C.D. Pa. 1805) (No. 2278) (Washington, Cir. Justice) (citing authority); Hart \& Wechsler, $3 \mathrm{~d}$ ed., supra note 241 , at 366-79; 393-95.

277. The one lower court case that Peller cites acknowledges that most lower federal courts on habeas corpus considered themselves bound by the same jurisdictional constraints as the Supreme Court. See $\ln$ re McDonald, 16 F. Cas. 17, 23, 25-26, 31 (E.D. Mo. 1861) (No. 8,751).

278. See Act of Sept. 24, 1789, ch. 20, § 14, 1 Stat. 73, 81-82.

279. Justice Johnson advanced exactly this position in dissents in Ex parte Watkins, 32 U.S. (7 Pet.) 567, 578-80 (1833), and Ex parte Bollman, 8 U.S. (4 Cranch) 74, 104-07 (1807); accord Ex parte Wells, 59 U.S. (18 How.) 307, 329 (1855) (Curtis, J., dissenting). The Court rejected this view in the cited cases and in Ex parte Siebold, 100 U.S. 371,377 (1879).

280. See, e.g., In re Kaine, 55 U.S. (14 How.) 103, 120-21 (1852) (Curtis, J., 
Second, the Brennan-Peller thesis encounters denials of the writ that cannot be explained as narrow contemporary constitutional interpretations. Although Brennan and Peller can easily explain Yick Wo, they are stumped by the Court's denial of relief in In re Wood, ${ }^{281}$ an important decision in the Bator chronology. ${ }^{282}$ In this 1891 case, the Court, through the first Justice Harlan, denied relief on a scrupulously preserved, impeccahly pleaded, and, if the allegations were true, patently meritorious jury discrimination claim. ${ }^{283}$ The Brennan-Peller explanation for this denial fails because the equal protection claim in Wood enjoys the same explicit constitutional status as the due process claims that Brennan and Peller believe were consistently cognizable on habeas corpus.

In addition, Brennan and Peller have the same difficulty Bator has explaining the divergent outcomes of Frank and Moore. If, as Brennan and Peller claim, Frank lost because the full and fair appellate affirmance of his guilt gave him all the process he was due, notwithstanding an unfair trial, there is no good reason why the Moore petitioners won after receiving the same appellate treatment.

Additionally, having used the Court's timing-focused, "in the first instance" language to counter Bator's preclusive interpretation of the exhaustion doctrine, ${ }^{284}$ Brennan and Peller have difficulty explaining language in the same cases that "leave[s] the petitioner to the usual and orderly course of proceeding" through the state process and "by writ of error from this court." 285 Nor does the Brennan-Peller explanation of the exhaustion doctrine satisfactorily counter Bator's skepticism about requiring state proceedings but giving their results no weight in subsequent federal proceedings. ${ }^{286}$ The "after you" formality that Brennan sees in the doctrine does little to avoid the offense that state judges take when a reviewing federal judge ignores their prior determinations. Moreover, the very decisions in which the Court lamented the writ's inflexible, unconditional-release remedy began developing the more flexible alternatives routinely used today. ${ }^{287}$ Thus, pace Peller, the habeas corpus statute's broad injunction to "dispose of [unconstitu-

concurring); In re Metzger, 46 U.S. (5 How.) 175, 190-91 (1847); Ex parte Bollman, 8 U.S. (4 Cranch) at 95-97.

281. 140 U.S. 278 (1891).

282. See Bator, supra note 6 , at $481-82$.

283. See In re Wood, 140 U.S. at 283-90. The Court previously recognized the right to relief on such claims on direct appeal in Neal v. Delaware, 103 U.S. 370, 397 (1880).

284. See Peller, supra note 191 , at 635 .

285. Whitten v. Tomlinson, 160 U.S. 231, 242 (1895) (relying on New York v. Eno, 155 U.S. 89, 93-95 (1894) and Ex parte Royall, 117 U.S. 241, 251-53 (1886)) (emphasis added); see, e.g., Urquhart v. Brown, 205 U.S. 179, 181-83 (1907); Tinsley v. Anderson, 171 U.S. 101, 104-05 (1898).

286. See Bator, supra note 6 , at 483 .

287. See, e.g., In re Bonner, 151 U.S. 242, 259-62 (1894); Medley, Petitioner, 134 U.S. $160,173-75$ (1890); see also supra note 263. 
tionally convicted prisoners] as law and justice require"288 gave habeas corpus courts ample alternatives to putting probably guilty individuals "back on the streets."

Examination of only a few landmark decisions reveals that neither Bator nor the Brennan-Peller thesis provides a complete or satisfying explanation of the Court's habeas corpus jurisprudence. To pose a further test for the two theories, and to help introduce my own, 1 will discuss two habeas corpus cases decided almost exactly a century ago. Although both seem to come straight out of Professor Bator's pantheon of review- and relief-denying cases, I use them to reveal a regime of rather broad federal review as of right that, although different from, is more akin to, the system that Justice Brennan and Professor Peller envisioned.

\section{B. Two Tests}

1. Whitten v. Tomlinson. $-\ln$ Whitten $v$. Tomlinson, ${ }^{289}$ petitioner George Whitten claimed that he had been improperly extradited from Massachusetts in January 1895 to stand trial for murder in Connecticut although (1) he had been " 'tried" " and discharged on the same counts " 'after a full hearing'" in a New Haven court in September 1893; (2) " "no indictment as and for a true bill ever was presented by any grand jury ... and any pretended indictment was found by mistake or misconception" "; and (3) he " "was not, at the time of his extradition ... a fugitive from justice" " as required by federal law. ${ }^{290}$ Sheriff Tomlinson's response-that he properly held Whitten under a mittimus sworn out by Whitten's surety averring that Whitten intended to abscond-prompted Whitten to claim that (4) the mittimus was an unfit basis for detention because it was directed to "Whitten, "of the town of Newton, . . . Massachusetts," " and Connecticut law authorized a mittimus only by " 'a justice of the peace of the county in which such principal resides," " and because the first Tuesday of January, 1895 specified for Whitten's appearance "was a day already passed" when the mittimus issued in March 1895. ${ }^{291}$ The circuit court denied relief, and the Supreme Court affirmed.

Justice Gray's conscientious effort to locate his analysis in both the statutory and case law context of federal question jurisdiction as a whole makes the decision a particularly helpful place to begin considering the writ's history. According to Gray, "three different methods have been provided by statute for bringing before the courts of the United States proceedings begun in the courts of the States" when "necessary to secure the supremacy of the Constitution, laws and trea-

288. Rev. Stat. $\S 761,18$ Stat. 143 (codified as amended at 28 U.S.C. $\S 2243$ (1988)).

289. 160 U.S. 231 (1895).

290. Id. at $233-34$.

291. Id. at $235,246$. 
ties of the United States."292 The first two extended respectively to judgments allegedly contrary to, and to claims arising under, "the Constitution, laws or treaties of the United States." They were direct Supreme Court review on writ of error under section 25 of the Judiciary Act of 1789 and section 2 of the Act of February 5, 1867,293 and removal to the lower federal courts under a series of acts passed, during periods of inter-sectional domestic crisis, in 1815-1817, 1833, and 1863-February 5, 1867.294

Third was habeas corpus:

By section 14 of the old [1789] Judiciary Act, the courts of the United States .were authorized ... to issue writs of habeas corpus and other writs necessary for the exercise of their respective jurisdictions; "provided that writs of habeas corpus shall in no case extend to prisoners in jail, unless when they are in custody under or by color of the authority of the United States, or are committed for trial before some court of the same...."

By subsequent acts of Congress, however, the power of the courts of the United States to issue writs of habeas corpus to prisoners in jail has been extended to the case of any person in custody for an act done or omitted in pursuance of a law of the United States, or of an order or process of a court or judge thereof [citing another provision of the 1833 act covered by Justice Gray's removal discussion]; or [ii] in custody in violation of the Constitution, or of a law or treaty of the United States [citing section 1 of the same February 5, 1867 Act cited in Justice Gray's writ of error discussion]. ${ }^{295}$

"By the existing statutes," Justice Gray concluded, now quoting the 1874 Revised Statutes' unified codification of all habeas corpus provisions, federal judges and courts have "power to grant writs of habeas corpus ... [to] any prisoner . . . 'in custody in violation of the Constitution, or of a law or treaty of the United States;' and '. . . shall forthwith award a writ of habeas corpus, unless it appears from the petition itself that the party is not entitled thereto." "296

292. Id. at 238.

293. See id. (citing, e.g., Act of Feb. 5, 1867, ch. 28, § 2, 14 Stat. 385, 385-86; Act of Sept. 24, 1789, ch. 20, $\$ 25,1$ Stat. 73, 85; Cohens v. Virginia, 19 U.S. (6 Wheat.) 264 (1821); Martin v. Hunter's Lessee, 14 U.S. (1 Wheat.) 304 (1816)).

294. See Whitten v. Tomlinson, 160 U.S. at 239; and, e.g., Act of Apr. 9, 1866, ch. 31, § 3, 14 Stat. 27 (amended, e.g., Act of Feb. 5, 1867, ch. 27, 14 Stat. 385); Act of Mar. 3 , 1863, ch. 81, §5, 12 Stat. 755, 756-57; Act of Mar. 2, 1833, ch. 57, § 3, 4 Stat. 632, 633-34; Act of Feb. 4, 1815, ch. 31, § 8, 3 Stat. 195, 198-99. See also Hart \& Wechsler, $3 \mathrm{~d}$ ed., supra note 241 , at $483-84,1767-69$ (discussing the removal acts).

295. Whitten v. Tomlinson, 160 U.S. at 239 (quoting Act of Sept. 24, 1789, ch. 20, $\S 14,1$ Stat. 73, 82; citing, e.g., Act of Feb. 5, 1867, ch. 28, § 1, 14 Stat. 385, 385-86; Act of Mar. 2, 1833, ch. 57, § 7, 4 Stat. 632, 634-35) (other citations omitted).

296. Whitten v. Tomlinson, 160 U.S. at 239-40 (quoting and paraphrasing Rev. Stat. $\$ \S 751-755,761$, tit. 13 , ch. 13,18 Stat. 142-43 (1878) (recodified and amended at 28 U.S.C. $\$ \S 2241(\mathrm{a})-(\mathrm{c}), 2243)$. 
Following Ex parte Royall ${ }^{297}$ and later "exhaustion" cases, however, Justice Gray stated that "in the exercise of this [habeas corpus] power the courts of the United States are not bound to discharge by writ of habeas corpus every such prisoner":

We cannot suppose that Congress intended to compel [federal] courts, by such means, to draw to themselves, in the first instance, the control of all criminal prosecutions commenced in state courts .... The [habeas corpus statute's] injunction to hear the case summarily, and thereupon "to dispose of the party as law and justice require," does not deprive the court of discretion as to the time and mode in which it will exert the powers conferred upon it. ${ }^{298}$

Thus, out of concern for " "relations existing . . . between the judicial tribunals of the Union and of the States," " federal courts "except in ... peculiar and urgent cases ... will not discharge the prisoner by habeas corpius in advance of a final determination of his case in the courts of the State," and even after determination by the highest state tribunal "will generally leave the petitioner to the usual and orderly course of proceeding by writ of error from this court."299

With this foundation, Justice Gray addressed the merits of Whitten's legal claims. In keeping with the Court's federal-prisoner habeas corpus precedents, Justice Gray acknowledged that Whitten's double jeopardy claim might have deserved attention had his prior "hearing and discharge" taken place at and following "a formal trial and acquittal," but rejected the claim because Whitten's allegations instead "point[ed] to a hearing and discharge upon an application for his committal to jail to await prosecution." 300 Reflecting the same precedents, Justice Gray reserved ruling on a claim " 'that no indictment was ever found against him by any grand jury" " but rejected Whitten's alternative claim "that an indictment, actually presented by the grand jury to the court, lacked the words 'a true bill," " and was handed down by "mistake and misconception." 301 These technical and state-law defects "afford[ed] no ground for interposition by the courts of the United

297. 117 U.S. $241,251-53$ (1886).

298. Whitten v. Tomlinson, 160 U.S. at 240-42 (quoting Ex parte Royall, 117 U.S. 241, 251-53 (1886)) (emphasis added)).

299. Id. at 240-42 (quoting Ex parte Royall, 117 U.S. at 251) (emphasis added).

300. Id. at 243. Compare, e.g., Ex parte Lange, 85 U.S. (18 Wall.) 163, 168-78 (1873) (under Double Jeopardy Clause, prior punishment upon conviction or prior acquittal bars subsequent conviction and punishment) with Ex parte Milburn, 34 U.S. (9 Pet.) 702, 709 (1835) (arrest following release on bail does not warrant habeas corpus relief because it does not violate double jeopardy principle).

301. Whitten v. Tomlinson, 160 U.S. at 243-45. Compare Ex parte Wilson, 114 U.S. 417, 429 (1885) (granting habeas corpus relief to prisoner tried for serious crime in federal court without grand jury indictment) with In re Coy, 127 U.S. 731, 753-56 (1888) (denying habeas corpus relief because of the alleged insufficiency of the indictment to show that a federal crime had occurred and because of other technical defects in the indictment). 
States by writ of habeas corpus."302 Justice Gray similarly rejected Whitten's claim that he was not a "fugitive from justice" within the meaning of federal law, as contrary to a factual finding, "proper in form," that the Court on habeas corpus would not revisit. ${ }^{303}$ Likewise beyond the Court's power to review was Whitten's claim that the bail-revoking court lacked personal jurisdiction under a state statute and under the proper reading of a state court's order, because neither theory arose under "the Constitution, or . . . a law or treaty of the United States."304

Having actually reviewed (and found unfit for habeas corpus consideration) all four of Whitten's pretrial, hence unexhausted, claims, Justice Gray foreswore similar consideration of the merits in the future should the Court again be presented with unexhausted claims. For there

could be no better illustration than this case ... of the wisdom $\ldots$ of the rule ... that a prisoner in custody under the authority of a State should not ... be discharged ... upon a writ of habeas corpus, in advance of any proceedings in the courts of the State to test the validity of his arrest and detention. ${ }^{305}$

2. In re Tyler. - Exemplifying the writ's surprisingly frequent use on behalf of state officials, ${ }^{306}$ In re Tyler ${ }^{307}$ involved the request of South Carolina sheriff M.V. Tyler for release from detention under a federal contempt order for violating an injunction against seizing property under the court's bankruptcy protection to pay state taxes the court deemed confiscatory. ${ }^{308}$

Tyler raised six claims-that (1) the absence of a sufficient amount in controversy and (2) the existence of an adequate remedy at law deprived the district court of jurisdiction to issue an injunction; ${ }^{309}$ that (3) the rule forbidding federal interference with state tax collection, (4) the Eleventh Amendment, or (5) a state law requiring aggrieved taxpayers to pay first and recoup later immunized Tyler from the injunction; and that (6) the taxes were not confiscatory. ${ }^{310} \mathrm{He}$ prefaced these claims with an overriding interpretive principle straight out of the BrennanPeller lexicon. Hoping to circumvent the cases suggesting "that the Supreme Court, having no jurisdiction of criminal cases by writ of error

302. Whitten v. Tomlinson, 160 U.S. at 244.

303. Id. at 245.

304. Id. at $240,246-47$.

305. Id. at 247.

306. See, e.g., In re Sawyer, 124 U.S. 200, 22 1-22 (I888); In re Ayers, 123 U.S. 443 (1887); Ex parte Rowland, 104 U.S. 604, 616-18 (188I).

307. 149 U.S. 164 (1893).

308. See id. at $169-70,190-91$.

309. Habeas corpus clearly lay by this time to release a contemnor detained by a court without jurisdiction over the lawsuit in which the injunction the prisoner violated was issued. See, e.g., In re Sawyer, 124 U.S. at 22 1-22; In re Ayers, 123 U.S. at 485; Ex parte Rowland, 104 U.S. at 617-18.

310. See In re Tyler, 149 U.S. at I81-83, 186-88, 190. 
or appeal, could not, on habeas corpus, examine into the sufficiency of the evidence on which the judgment and sentence of the court was founded," Tyler argued that Congress' authorization of criminal appeals two years earlier had removed any "obstacle" to the use of the writ to "inquir[e] into the sufficiency of the evidence on which the judgment was founded and into errors of law beyond jurisdictional errors."311

Because of doubts that the 1891 criminal appeals provision reached quasi-criminal contempt convictions, the Court excused Tyler's failure to exhaust federal appellate remedies. Stating in passing a principle that telegraphs my interpretation of the writ's 200 -year history, Chief Justice Fuller reasoned that

[t]he writ of habeas corpus is not to perform the office of a writ of error or appeal; but when no writ of error or appeal will lie, if a petitioner is imprisoned under a judgment of [a court] ... which had no jurisdiction of the person or of the subject matter, or authority to render the judgment complained of, then relief may be accorded. ${ }^{312}$

Obviously, the principle that the writ substitutes for an appeal when the latter is not available is the very opposite of the principle for which Tyler contended-namely, that the writ duplicates whatever appeals are available. Chief Justice Fuller thus concluded that even if, under the 1891 act, "a writ of error might be brought to review . . . a [contempt] judgment[,] . . . and . . . thereby our appellate jurisdiction was enlarged, we should still decline to consider the whole record for error merely, but only to ascertain whether the judgment was absolutely void."31s

Next distinguishing "error merely" from an "absolutely void" judgment-that is, a judgment rendered in the absence of "jurisdiction of the person or of the subject matter, or authority to render the judgment complained of "- the Court ruled that the existence of an adequate remedy at law was not cognizable on habeas corpus because it "goes to the want of equity and not to want of power."314 Similarly, "an apparent defect of jurisdiction for lack of a [sufficient] matter in controversy ... can be availed of only by appeal or writ of error" and not on habeas corpus because it does not involve "an absolute want of power" but only "its defective exercise." 315

Then, after repeatedly noting that the "cause [was] confessedly within [the federal circuit court's] jurisdiction,"316 Justice Gray exten-

311. Id. at 173 .

312. Id. at 180 .

313. Id. at $180-81$.

314. Id. at 180 .

315. Id. at 181 (citing Reynes v. Dumont, 130 U.S. 354 (1889); In re Sawyer, 124 U.S. 200, 221 (1888)).

316. Id. at 190; accord id. at 181, I89 ("The property in question was in the 
sively discussed and eventually denied the legal merits of Tyler's claims that anti-tax-injunction principles and the Eleventh Amendment immunized state officials from the federal court's power, via injunction and contempt, to protect the property within its jurisdiction from excessive state taxation. ${ }^{317}$ The Court then brushed aside Tyler's claim under the state's "pay now, recoup later" provision as outside the Court's jurisdiction, and dispatched his claim that the taxes were not unconstitutionally excessive on the ground that the confiscation question was "for the Circuit Court to determine ... , and its action cannot be treated as a nullity."318

3. Analysis. - On the exhaustion of remedies issue, neither the $\mathrm{Ba}$ tor nor the Brennan-Peller thesis can explain what went on in Whitten and Tyler. Thus, Bator can explain Whitten's promise to "leave" future petitioners to remedies besides habeas corpus, but not its explanation of exhaustion as simply requiring state court consideration "in the first instance." Brennan and Peller's problem is exactly the reverse.

On the cognizability issue, consider first what Whitten and Tyler said. Whitten could hardly be more explicit, stating the question presented as whether petitioner's claims placed "the supremacy of the Constitution, laws and treaties of the United States" at stake. ${ }^{319}$ Tyler's language is less explicit, but its concern for "question[s] of power," whether the judgment "was absolutely void," and whether the committing court "had ... jurisdiction of the person or the subject matter, or authority to render the judgment complained of " transcends jurisdictional questions and rather precisely track the era's definition of due process. $^{320}$

Both the Whitten and Tyler Courts were true to their word. Justice Gray did not hold-as he much more easily and briefly could havethat, not being dispositive of the detaining court's subject matter or personal jurisdiction, the double jeopardy and right-to-indictment claims were outside the Court's habeas corpus authority. Rather, Justice Gray was at pains to show that Whitten did not allege a constitutional violation, and at best alleged only technical error. Likewise,

custody of the Circuit Court, in a cause within its jurisdiction, and protected by injunction.").

317. See id. at 189-91.

318. Id. at 188-91

319. Whitten v. Tomlinson, 160 U.S. 231,238 (1895).

320. In re Tyler, 149 U.S. at 180-81, 188-89 (emphasis added); accord Tinsley v. Anderson, 171 U.S. 101, 106 (1898) (due process is not denied "[i]f the committing court had jurisdiction of the subject-matter, and of the person, and power to make the order"); In re Converse, 137 U.S. 624, 631 (1891) (due process violation requires "such an unrestrained and arbitrary exercise of power as to be utterly void"); Kennard v. Louisiana ex rel. Morgan, 92 U.S. 480, 481 (1875) (to satisfy due process, act must be "done 'in the due course of legal proceedings" " and be taken by courts with "power ... to proceed at all"; due process is not offended by "[i]rregularities and mere errors in the proceedings"). 
Chief Justice Fuller's repeated conclusions that the detaining court had jurisdiction did not stop him from reviewing Tyler's nonjurisdictional constitutional defenses based on federalism and anti-tax-injunction principles.

Even more intriguing are both decisions' limitation of the habeas corpus power to less than all jurisdictional claims. Thus, the Whitten Court categorized as nonreviewable "error merely" three claims that, if true, defeated the detaining court's personal jurisdiction, namely, (1) that Whitten was not a "fugitive from justice" under federal law, thus forbidding his extradition; (2) that the state court could not arrest Whitten, a nondomiciliary, under a state law applying only to "reside[nt]s"; and (3) that his detention order, which seemed to terminate in January, was moot in March. Likewise, in Tyler, the Court placed beyond the pale of its habeas corpus power the clearly jurisdictional claim that the lawsuit before the court lacked the jurisdictionally requisite amount in controversy. ${ }^{321}$

What emerges from Whitten and Tyler is not a distinction between jurisdictional and nonjurisdictional claims, but rather a distinction between more and less fundamental types of claims, be they jurisdictional or not. On its face, this distinction seems more compatible with Brennan and Peller's theory than with Bator's. Still, the Court's application of the distinction presents problems for Brennan and Peller. Thus, any simple and straightforward application of the 1867 statute's grant of habeas corpus power over claims arising under the "Constitution and laws of the United States" should have comprehended both Whitten's claim that he was not a "fugitive from justice" within the meaning of the federal extradition law and Tyler's claims that the statutorily mandated amount in controversy was absent and that the taxes he was collecting were not confiscatory in violation of the Fourteenth Amendment. Even more troublesome for Brennan and Peller is Tyler's outright rejection of the argument that gaps in the Court's habeas corpus jurisdiction could be attributed to gaps in its criminal appellate jurisdiction. ${ }^{322}$

In the end, neither Bator nor Brennan and Peller offer particularly satisfactory explanations of the Court's habeas corpus cases. The reason may emerge from an aspect of Justice Gray's careful exposition in Whitten that indicts both theses. Unlike these later theorists, Justice Gray directs attention not simply to the Court's habeas corpus precedents but also to the legislation governing the writ and, most fundamentally, to the precedents and statutes governing all "methods" by which federal review of state criminal judgments "secure[s] the supremacy of the Constitution, laws and treaties of the United 
States." 323 Following Justice Gray's lead, let me state my own thesis and attempt to defend it by placing it within tbe statutory and federalquestion contexts that Justice Gray emphasized in Whitten.

\section{V. A New History of Habeas Corpus in Statutory and Federal JURISDICTIONAL CONTEXT}

\section{A. A New Thesis}

In its 1942 decision in Waley $v$. Johnston, ${ }^{324}$ the Supreme Court had the good sense to crib a single, overarching habeas corpus rule from a brief filed in an earlier case by a young government lawyer named Herbert Wechsler:325 The writ "extends . . . to those exceptional cases where the conviction has been in disregard of the constitutional rights of the accused, and where the writ is the only effective means of preserving his rights." 326

Although Wechsler apparently dated this rule, and the modern era of habeas corpus jurisprudence generally, from the Court's decision in Moore twenty years earlier, ${ }^{327}$ I think that, even in 1942, the rule had more than two decades' worth of explanatory power. With some modifications, it now can claim two centuries' worth. Indeed, a version of the same rule emerged from Tyler's I893 statement that "when no writ of error or appeal will lie, if a petitioner is imprisoned under a judgment of the Circuit Court, which had no jurisdiction of the person or of the subject matter, or authority to render the judgment complained of, then relief may be accorded." 328

Combining both versions of the rule, let me state my thesis as follows: Federal habeas corpus is not a substitute for a general writ of error or other direct appeal as of right. Since 1789, however, it has provided statutorily specified classes of prisoners with a limited and substitute federal writ of error or appeal as of right. That appellate procedure has been limited because it has lain only to hear claims of particular national importance-which Congress since 1867 has defined as all constitutional claims. It has been a substitute because it bas served only in default of Supreme Court review as of right.

The limited class of nationally important claims cognizable in habeas corpus has changed over time under the influence of (1) constitutional and statutory limitations on the federal courts' jurisdictionclaims arising under state law, even if jurisdictional, have never been cognizable; ${ }^{329}$ (2) case law identifying the legal defects in civil cases that

323. Whitten v. Tomlinson, 160 U.S. at 238.

324. 316 U.S. 101 (1942).

325. See Wechsler, supra note 264 , at 174 .

326. Waley v. Johnston, 316 U.S. at 105.

327. See Wechsler, supra note 264 , at $172-73$.

328. In re Tyler, 149 U.S. 165,180 (1893).

329. See, e.g., In re Converse, 137 U.S. 624, 630-31 (1891). 
are subject to collateral attack; ${ }^{330}$ and (3) developing notions of due process and constitutional law. ${ }^{331}$ At no time was the line between jurisdictional and nonjurisdictional claims a very good proxy for this line between important and unimportant claims.

As a substitute for federal direct appeal, habeas corpus has never duplicated, but has always mirrored the scope of, Supreme Court review on direct appeal. Although the line between legal and factual questions has changed over time, the scope of both modes of review has always been de novo on legal claims and deferential-to-nonexistent on factual findings.

"Innocence" claims and their close cousins, claims that the penal statute was not intended to reach the particular prisoner's conduct, are both nationally unimportant because sui generis, and subject to little or no review because aimed at the central fact determination at trial. For these reasons, the Court has been particularly careful to exclude such claims from habeas corpus. ${ }^{332}$

Before embarking on an effort to show how most or all the Court's cases map onto this rule, let me show how Whitten and Tyler do. My thesis, unlike Bator's or Brennan-Peller's, explains how the exhaustion doctrine can be both a rule of timing-requiring that nonpreclusive state court review precede federal review ${ }^{393}$ _and a rule of preclusion-making federal direct review as of right preclusive of later habeas corpus review. My thesis also explains, as Brennan and Peller cannot, why Tyler treated Congress' creation of federal-prisoner appeals as of right to the Supreme Court as an occasion not for expanding but instead for contracting habeas corpus review.

Likewise, the thesis does a better job than Bator's or BrennanPeller's of explaining the treatment of the claims in the two cases. Although jurisdictional and federal-statutory, Whitten's "fugitive from justice" and Tyler's "amount in controversy" claims were fact-bound, so that the prior courts' determinations were binding. The same goes for Tyler's constitutional claim that the taxes were not confiscatory. ${ }^{334}$

330. See, e.g., Cuddy, Petitioner, 131 U.S. 280, $284-85$ (1889); Ex parte Lange, 85 U.S. (18 Wall.) 163, 177-78 (1874); Ex parte Watkins, 28 U.S. (3 Pet.) 193, 203-07 (1830).

331. See, e.g., Frank v. Mangum, 237 U.S. 309, 326-28 (1915); Yick Wo v. Hopkins, 118 U.S. 356, 369-70, 373-74 (1886); Ex parte Lange, 85 U.S. (18 Wall.) at 176-77; see also Ex parte Parks, 93 U.S. 18, 21 (1876) (the writ "is one of the modes in which this court exercises supervisory power over inferior courts and tribunals; but it is a special mode, and confined to a limited class of cases") supra note 41 (discussing the liberty interests definitive of "important" or "fundamental" national laws).

332. But see Herrera v. Collins, $112 \mathrm{~S}$. Ct. 1074 (1992) (mem.) (granting certiorari in Herrera v. Collins, 954 F.2d 1029 (5th Cir. 1992), to decide whether petitioner's innocence by itself is cognizable on habeas corpus as a constitutional defense to execution).

333. A final judgment by the highest state court with jurisdiction is a statutory prerequisite to federal direct review. See supra note 8 and accompanying text.

334. Confiscation was not then, or even as late as 1920 , a mixed question of law 
Whitten's jurisdictional claims attacking the state trial court's authority to order his detention and alleging the detention order's mootness, as well as Tyler's claim based on South Carolina's "pay now, recoup later" statute, were noncognizable state law claims, while Whitten's bail-revocation and defective-indictment claims alleged "mere" or technical error at best. Only, therefore, the Fifth Amendment indictment and double jeopardy claims hinted at but not established by Whitten's petition and Tyler's Eleventh Amendment and federalism-based-immunity claims rose to a level of national importance sufficient to warrant the federal courts' attention on habeas corpus. ${ }^{335}$

Thus far, I have implicitly used my thesis, in Parts I and II, to explain the habeas corpus cases from 1953 to the 1990s, and have explicitly used it, in Part III.B, to explain two I890s cases. In the remainder of this Part, I use the thesis to generate a new history of habeas corpus in statutory and federal jurisdictional context, in the process assimilating the rest of the cases.

\section{B. Federal Question Writs of Error and Habeas Corpus Review Under the 1789 Judiciary Act}

As we already know from Justice Gray's summary in Whitten, ${ }^{336}$ section 25 of the First Judiciary Act of 1789 extended writs of error as of right to state prisoners (and other state litigants) who, within the preceding five years, had been denied relief "in the highest court of law ... of a State in which a decision in the suit could be had" on claims challenging a state statute or other state authority "on the ground of [its] being repugnant to the constitution, treaties or laws of the United States" or questioning "the construction of ... the constitution, ... . a treaty, or statute of ... the United States."337 Reflecting the common law use of the writ of error as a means of bringing up for review only some of the issues in a case, ${ }^{338}$ section 25 stated that:

no other error shall be assigned or regarded as a ground of reversal in any such case as aforesaid, than such as appears on the face of the record, and immediately respects the before mentioned questions of validity or construction of the said constitution, treaties, statutes, commissions, or authorities in dispute. ${ }^{339}$

Although section 25 provided without limitation that the state

and fact. See Ohio Valley Water Co. v. Ben Avon Borough, 253 U.S. 287, 299 (1920)

(Brandeis, J., dissenting).

335. See supra notes 300-304, 314-318 and accompanying text.

336. See supra notes $292-293$ and accompanying text.

337. Act of Sept. 24, 1789, ch. $20 \S 25,1$ Stat. 73, 85-86; see id. $\S 22,1$ Stat. at 84, incorporated by reference in id. $\S 25,1$ Stat. at 86 (five-year period in which to file).

338. See supra note 51 .

339. Act of Sept. 24, 1789, ch. 20, $§ 25,1$ Stat. 73, 86-87 (emphasis added). 
court "judgment . . . may be re-examined and reversed or affirmed," 340 the Court, following common law appellate practice, interpreted its writ of error power to permit de novo review only of legal claims and to forbid review of purely factual determinations. ${ }^{341}$ This inclination took on something of a constitutional imperative in 1791, when the Seventh Amendment became law, forbidding the federal courts to overturn the factfinding of a jury except according to these same common law usages. ${ }^{342}$

Sections 9 and 11 of the 1789 Act gave federal district and circuit courts jurisdiction to try criminal cases arising under federal penal statutes. ${ }^{343}$ Sections 21 and 22 established the appellate jurisdiction of the federal circuit courts and the Supreme Court, but made no provision for appeals in criminal cases. ${ }^{344}$

Section 14 of the 1789 Act gave federal, but expressly withheld from state, prisoners the right to petition for writs of habeas corpus to review the "cause of commitment." 345 Although the statute did not expressly give the Supreme Court itself-only its individual Justices (along with lower federal courts and judges) - the power to issue the writ, the Court quickly held that the statute accorded the entire Court the power to grant habeas corpus relief. ${ }^{346}$ In so holding, Justice Marshall rejected the Government's double-barreled claim that the Court, as a court, had no habeas corpus jurisdiction (i) because, citing Marbury v. Madison,,$^{\mathbf{3 4 7}}$ the Constitution's strict limits on the Court's original jurisdiction forbade the Court to hear habeas corpus petitions filed directly before it, and (ii) because the 1789 statute failed to authorize appeals from lower federal courts in habeas corpus cases, thus denying the constitutionally required authorization of appellate power. ${ }^{348}$ In a ruling that reverberated throughout the Court's nineteenth century habeas corpus cases, the Court avoided both claims by ruling (1) that habeas corpus was "clearly appellate" because it involved "the revision of a decision of an inferior court, by which a citizen has been committed to jail," and (2) that Congress through section 14 had given the full Court the constitutionally requisite authorization, in the exercise of its

340. Id. § 25, 1 Stat. at 85-86 (emphasis added).

341. See supra note 51 .

342. See U.S. Const. amend. VII; The Justices v. Murray, 76 U.S. (9 Wall.) 274, 277-80 (1869); Hart \& Wechsler, 3d ed., supra note 241, at 19-20; supra note 51.

343. See Act of Sept. 24, 1789, ch. 20, $\$ \$ 9,11,1$ Stat. 73, 76-79.

344. See id. $\S \S 21,22,1$ Stat. 73, 83-85.

345. Id. $\S 14,1$ Stat. 73, 81-82.

346. See Ex parte Milligan, 71 U.S. (4 Wall.) 2, 110 (1866); Ex parte Bollman, 8 U.S. (4 Cranch.) 75, 96, 100 (1807); see also Ex parte Burford, 7 U.S. (3 Cranch) 448, 452-53 (1806) (exercising the power the Court explicitly affirmed in Bollman); United States v. Hamilton, 3 U.S. (3 Dall.) 17, 18 (1795) (same).

347. 5 U.S. (1 Cranch) 137 (1803).

348. See Ex parte Bollman, 8 U.S. (4 Cranch) at 96-101. 
appellate jurisdiction, to hear "original" habeas corpus petitions. ${ }^{349}$ Essentially until 1885, therefore, the Court routinely heard habeas corpus petitions arising in one of two postures-filed initially in the Supreme Court with no lower court action on habeas corpus, ${ }^{350}$ or filed in a lower federal court followed by the filing in the Supreme Court of an "original" habeas corpus petition and a petition for a writ of certiorari to bring the lower court's record before the Supreme Court. ${ }^{351}$

The 1789 Act's authorization to inquire into the "cause of commitment" powered the Court's entire habeas corpus jurisprudence between 1789 and at least $1874 .^{352}$ Contrasting the nine federal-prisoner habeas corpus cases during the period in which the Court granted review, including the six in which it granted relief, with the two in which it denied review based on substantive limits on the scope of the writ ${ }^{353}$ reveals that, pace Bator, the 1789 Act cases did not limit habeas corpus review either to jurisdictional claims or to claims attacking pretrial as opposed to postconviction detention. In three of the cases in which the Court granted relief, and in at least one of those in which it granted review but denied relief, the detaining authority clearly had jurisdiction to detain the petitioner. ${ }^{354}$ And in two of the cases in which it granted

349. Id. at I00-01; accord Ex parte Siebold, 100 U.S. 371, 374 (1879); Ex parte McCardle I, 73 U.S. (6 Wall.) 318, 324 (1867); Ex parte Watkins II, 32 U.S. (7 Pet.) 568, 572-73 (1833); supra notes 275-278. Sections 13 and 14 of the 1789 Act may themselves identify habeas corpus as appellate. After laying out the Court's original jurisdiction, $\S 13$ says that " $[t]$ he Supreme Court shall also have appellate jurisdiction from the circuit courts and courts of the several states, in the cases herein after specially provided for" and is followed immediately by $\S[4$, which "[ $t]$ herein after specially provide[s]" for writs of habeas corpus. Act of Sept. 24, 1789, $\$ \$ 13,14,1$ Stat. 73, 80-82.

350. See, e.g., Ex parte Kearney, 20 U.S. (7 Wheat.) 38, 39-44 (1822). But cf. In re Metzger, 46 U.S. (5 How.) I76, 19I-92 (1847) (forbidding review of executive detention as not appellate and beyond the Court's constitutionally specified original jurisdiction).

351. See, e.g., Ex parte Yerger, 75 U.S. (8 Wall.) 85, 99-I01 (I868); In re Kaine, 55 U.S. (14 How.) 103, 116 (1852).

352. See infra notes $390-392$ and accompanying text (gradual replacement of 1789 Act by 1867 Act during 1874-1885 period).

353. Granting habeas corpus review and relief are United States v. Hamilton, 3 U.S. (3 Dall.) 17 (1795); Ex parte Burford, 7 U.S. (3 Cranch) 448 (1806); Ex parte Bollman, 8 U.S. (4 Cranch) 75 (1807); Ex parte Watkins II, 32 U.S. (7 Pet.) 568 (1833); Ex parte Milligan, 7I U.S. (4 Wall.) 2 (1866); Ex parte Lange, 85 U.S. (18 Wall.) 163 (1874). Granting review but denying relief are Ex parte Milburn, 34 U.S. (9 Pet.) 704 (1835); In re Kaine, 55 U.S. (I4 How.) I03 (I852); Ex parte Wells, 59 U.S. (18 How.) 307 (1855). Denying review based on substantive limits on the scope of the writ are Ex parte Kearney, 20 U.S. (7 Wheat.) 38 (1822); Ex parte Watkins, 28 U.S. (3 Pet.) 193 (1830).

354. Granting relief on nonjurisdictional claims are Ex parte Lange, 85 U.S. (18 Wall.) at 175 (curing double jeopardy violation); Ex parte Bollman, 8 U.S. (4 Cranch) at 135 (overturning lower court's arrest warrant for lack of probable cause although issuing court had jurisdiction); Ex parte Hamilton, 3 U.S. (3 Dall.) at 18, (similar). Hearing but denying relief on a nonjurisdictional claim is Ex parte Milburn, 34 U.S. (9 Pet.) at 710 (denying relief on double jeopardy claim allegedly committed by court with unchallenged jurisdiction). 
relief, the Court overturned what amounted to criminal convictions. ${ }^{355}$

On the other hand, in the famous case of Ex parte Watkins, ${ }^{356}$ the Court denied habeas corpus review of two challenges to the jurisdiction of the detaining Court-that the petitioner's conduct lay outside the proscription of the federal statute under which he was convicted, hence outside the detaining court's subject-matter jurisdiction, and that the petitioner's actions took place in another state, thus depriving the court of personal jurisdiction. ${ }^{357}$ Nor did Watkins and the Court's other cases claim to limit habeas corpus review to jurisdictional claims, but instead identified as equally critical whether the detaining court acted without "authority" or "unlawfully."358

What the Justices instead did during this period was to grant relief on the basis of legal claims of national importance-mainly constitutional claims-including whether the court that ordered the petitioner's arrest lacked probable cause to believe a crime had been committed, in violation of the Fourth Amendment; ${ }^{359}$ whether a court convicted the petitioner without the rudiments of a trial, or at least without a jury and a life-tenured judge as required by Article III and the Sixth Amendment; ${ }^{360}$ whether the detaining court had twice placed the petitioner in jeopardy by imposing two punishments for a single offense, in violation

355. See Ex parte Milligan, 71 U.S. (4 Wall.) at 122-23 (civilian's conviction by military court violated constitutional right to trial by jury before a life-tenured judge); Ex parte Burford, 7 U.S. ( 3 Cranch) at 453 (summary incarceration and fine imposed by justices of the peace after finding the petitioner to be of "ill fame" overturned for lack of "proceedings [that] are regular").

356. 28 U.S. (3 Pet.) 193 (1830).

357. See id. at 197, 201 (claims "that no offence was charged in the indictments, which was within the jurisdiction of the circuit court for the county of Washington" and "that the indictment charges no offense for which the prisoner was punishable in that court, or of which that court could take cognisance; and consequently, that the proceedings are coram non judice").

358. See, e.g., Ex parte Lange, 85 U.S. (18 Wall.) at 166 ("whether th[e detaining] court has exceeded its authority"); Ex parte Milligan, 71 U.S. (4 Wall.) at 116, 118 ("lawfulness of . . . imprisonment"); In re Metzger, 46 U.S. (5 How.) 176, 191 (1847) ("legality of the commitment"); Ex parte Watkins, 28 U.S. (3 Pet.) at 202 (same).

359. The dissenting judge in the lower court in Bollman, whose conclusion the Supreme Court accepted on appeal, see supra note 354 (summarizing Bollman), described the claim in that case as arising under the Fourth Amendment. United States v. Bollman, 24 F. Cas. 1189,1192 (C.C.D.C. 1807) (No. 14,622) (Cranch, J., dissenting); see also Ex parte Milburn, 34 U.S. (9 Pet.) 704, 705 (1835) (district attorney's issuance of arrest warrant violated Fourth Amendment requirement of action by magistrate); Ex parte Burford, 7 U.S. (3 Cranch) 448, 452, 453 (1806) (granting relief in part "for want of [a warrant] stating some good cause certain, supported by oath").

360. See, e.g., Ex parte Milligan, 71 U.S. (4 Wall.) at 122; Ex parte Burford, 7 U.S. (3 Cranch) at 452,453 (apparently treating lack of jury trial as reason to grant writ and order trial "de novo" with "regular" proceedings); United States v. Hamilton, 3 U.S. (3 Dall.) 17 (1795); see also Ex parte Randolph, 20 F. Cas. 242, 254-55 (C.C.D. Va. 1833) (No. 11,558) (Marshall, Cir. Justice) (assuming cognizability of claim that statute violated Article IIl and the Fourth, Fifth, Sixth, and Seventh Amendments). 
of the Fifth Amendment; ${ }^{361}$ and whether the statute under which the petitioner was convicted was unconstitutional. ${ }^{362}$ And when the Court denied relief on the merits, it did so only after satisfying itself that no constitutional violation had occurred. ${ }^{363}$

Furthermore, in the two cases in which the Court denied review, in both cases because the writ could not substitute for a plenary appeal, ${ }^{364}$ it did so expressly on the ground that habeas corpus instead provided review that, although concededly "in the nature of a writ of error," only reached a limited range of claims. ${ }^{365}$ And its holdings demarcate that limit precisely according to the important-unimportant line hypothesized above. Thus, the Court refused to hear even jurisdictional claims that merely challenged the sufficiency of the evidence to convict or asserted that the particular conduct for which the petitioner had been convicted fell outside the penal statute. ${ }^{366}$

Moreover, the scope of review that the Court afforded on habeas corpus precisely tracked that available on direct appeal. Thus, as section 25 expressly required on writ of error review, ${ }^{367}$ the Court limited its habeas corpus review to reexamination of legal determinations ${ }^{368}$ ap-

361. See Ex parte Lange, 85 U.S. (18 Wall.) at 169.

362. See Ex parte Randolph, 20 F. Cas. at 253-56 (dicta by Marshall, Cir. Justice).

363. Ex parte Wells, 59 U.S. (18 How.) 307, 310-15 (1855) (President's pardoning power authorizes commutation of a death sentence on condition that petitioner accept life imprisonment); In re Kaine, 55 U.S. (14 How.) 103, 110 (1852) (federal statute constitutionally permitted foreign government to move in court to extradite petitioner without President's concurrence); Ex parte Milburn, 34 U.S. (9 Pet.) at 708-10.

364. See Ex parte Watkins, 28 U.S. (3 Pet.) 193, 203 (1830); Ex parte Kearney, 20 U.S. (7 Wheat.) $38,44-45$ (1822).

365. Ex parte Watkins, 28 U.S. (3 Pet.) at 202-03. The thesis presented here thus explains the puzzling juxtaposition of statements that habeas corpus does not comprehend the "power to examine the proceedings, on a writ of error" but is "in the nature of a writ of error, to examine the legality of the commitment." Id. Chief Justice Marshall was not contradicting himself: habeas corpus does not "examine [all] the proceedings," as might occur on an appellate court's plenary writ of error, but only a limited set of issues, namely, "the legality of the commitment." As to cognizable issues, however, review is "in the nature of a writ of error."

366. See, e.g., Ex parte Watkins II, 32 U.S. (7 Pet.) 568, 574 (1833) (refusing review of claim that statutorily permissible $\$ 3000$ fine was excessive); Ex parte Watkins, 28 U.S. ( 3 Pet.) at 207 (refusing review of claims that federal penal law did not comprehend the charged embezzlements, and that crime of paying out money in Boston and New York embezzled from government in Washington did not take place in Washington); Ex parte Kearney, 20 U.S. (7 Wheat.) at 45 (refusing to review lower court's finding that witness was in contempt for refusing to answer questions).

367. See supra notes 338-342 and accompanying text.

368. See, e.g., Ex parte Milligan, 71 U.S. (4 Wall.) 2, 112-13, 118 (1866); Ex parte Watkins, 28 U.S. (3 Pet.) at 203-07; Ex parte Kearney, 20 U.S. (7 Wheat.) at 42 (reviewing de novo question whether "commitment was made by a court of competent jurisdiction . . . in the exercise of an unquestionable authority"); Ex parte Bollman, 8 U.S. (4 Cranch) 75, 114, 125, 135-36 (1807) (defining scope of review as "do[ing] that which the court below ought to have done," Court "fully examine[d] and attentively consider[ed]" whether probable cause existed). 
pearing "on the face" of the record. ${ }^{369}$

ln short, the experience under the 1789 Act was entirely consistent with the writ's use as a substitute for direct Supreme Court review of nationally important questions as of right on the merits in situations in which the latter review was not meaningfully available. Having withheld from federal prisoners any right to a plenary direct appeal, the Act granted them instead the more limited, but still appellate, remedy of habeas corpus review of fundamental (typically, constitutional) legal claims. Having granted state prisoners a writ of error as of right to challenge the state court's adverse constitutional decisions, the Act explicitly withheld substitute habeas corpus review.

\section{The Antebellum Removal and Habeas Corpus Acts}

In 1815-1817 and 1833, when the New England states and then South Carolina threatened to "nullify" national revenue legislation by prosecuting federal officers who enforced it, Congress suddenly found that forcing this class of state prisoners to await their postconviction and post-appeal writ of error remedies would indeed nullify nationally important laws. ${ }^{370}$ Congress accordingly authorized federal officers detained by state courts for acts undertaken "in pursuance of a law of the United States"371 to seek either removal or habeas corpus redress in the lower federal courts in advance of their inadequate writ of error remedies. ${ }^{372}$ Moreover, in the 1850 s, when state prosecutions of federal marshals threatened the enforcement of the Fugitive Slave Act, the lower federal judiciary, often acting through Supreme Court Justices on circuit, repeatedly interpreted the 1833 habeas corpus provisions to permit review de novo ${ }^{373}$-after conviction as well as before ${ }^{374}$-of the officials" "pursuance of federal law" defenses. For the first time, moreover, habeas corpus review was understood to permit inquiry beyond

369. See, e.g., Ex parte Lange, 85 U.S. (18 Wall.) 163, 176 (1873); Ex parte Watkins, 28 U.S. (3 Pet.) at 202-03. Drawn from common law constraints on the ability of one court to attack collaterally the judgment of another, the "on the face" limitation on habeas corpus (and writs of error) strongly reinforced the Court's reluctance to consider sufficiency claims and claims that the petitioner's particular conduct lay outside the penal statute's proscription, which perforce required the reviewing court to "look behind" the judgment of conviction to the evidence or at least to the indictment. See id. at 203-07.

370. See authority cited supra notes 292-296.

371. Act of Mar. 2, 1833, ch. 57, \& 7, 4 Stat. 632, 634.

372. See supra notes $294-296$ and accompanying text.

373. See, e.g., Ex parte Sifford, 22 F. Cas. 105, $107-08$ (D.C.S.D. Ohio 1857) (No. 12,848) (citing cases); Ex parte Robinson, 20 F. Cas. 965, 966, 968 (C.C.S.D. Ohio 1856) (No. 11,934); Ex parte Jenkins, 13 F. Cas. 445, 447 (C.C.E.D. Pa. 1853) (No. 7,259) (Grier, Cir. Justice); id. at 451, 459-60 (Kane, D.J.).

374. See, e.g., Electoral College Case, 8 F. Cas. 427, 431, 433, 434 (C.C.S.C. 1876) (No. 4336) (Bond, Cir. J.); Ex parte Robinson, 20 F. Cas. at 965-66 (granting relief after conviction); Ex parte Jenkins, $13 \mathrm{~F}$. Cas. at 451 (granting relief pretrial and saying that the same result would occur post-trial). 
the face of the commitment papers, into the substance of the federal officials' "pursuance" claims. ${ }^{375}$

\section{The Reconstruction Era Accretions to the Federal Courts' Writ of Error, Removal, and Habeas Corpus Jurisdiction}

The use of the 1833 habeas corpus and removal powers to enforce the hated Fugitive Slave Law fresh in its members minds, the Reconstruction Congress adapted both techniques to its own purposes in a series of acts passed in 1863,1866, and on February 5, 1867.376 One of the two acts passed on this last day also broadened the Supreme Court's writ of error jurisdiction to review federal questions arising in state courts. ${ }^{377}$ Through these acts, Congress made a series of parallel expansions of all three modes of federal court review of state court criminal actions.

The legislation widened the range of claims cognizable in all three types of proceedings up to Article III's federal-question maximum. ${ }^{378}$ The new removal and habeas corpus provisions expanded the range of prisoners protected to all those with federal claims. ${ }^{379}$ The new habeas corpus and writ of error provisions expressly overturned case law (in the case of habeas corpus) and legislation (in the case of writs of error) that previously had limited those modes of review to federal "error ... as appears on the face of the record." 380 Accordingly, what the Supreme Court said of the February 5, 1867 habeas corpus legislation when it first interpreted it that same year might just as well have been said of all three types of legislation that Congress passed that day: "This legislation is of the most comprehensive character. ... It is impos-

375. See authority cited supra note 373. The Supreme Court later validated these interpretations of the 1833 Act. See In re Neagle, 135 U.S. 1, 42, 53, 69-74 (1890).

376. See supra notes 292-295 and accompanying text.

377. See supra note 293 and accompanying text.

378. See Civil Rights Act of 1866, ch. 31, §§1, 3, 14 Stat. 27 (removal rights available to all persons seeking to enforce "full and equal benefit of all laws and proceedings" for the enforcement of various civil rights); Act of Feb. 5, 1867, ch. 28, $\S 1,14$ Stat. 385 (claims cognizable on habeas corpus expanded to include "all cases where any person may be restrained of his or her liberty in violation of the constitution, or of any treaty or law of the United States" (emphasis added)); id. § 2, 14 Stat. at 386-87 (broadening cognizable claims in ways catalogued in Hart \& Wechsler, 2d ed., supra note 38 , at $439-40 \& \mathrm{nn} .2-5$ ).

379. See supra notes 293-296, 378 and accompanying text. The February 5, 1867 removal act was particularly designed to facilitate the use of the procedure by criminal defendants, as opposed to other litigants with federal claims. See Act of Feb. 5, 1867, ch. 27, 14 Stat. 385.

380. Act of Sept. 24, 1789, ch. 20, § 25, 1 Stat. 73, 86-87, repealed by Act of Feb. 5,1867 , ch. 28, \& 2, 14 Stat. 385, 386-87 (discussed in Hart \& Wechsler, 2d ed., supra note 38, at 440 \& n.7); accord Act of Feb. 5, 1867, ch. 28, § 1, 14 Stat. 385-86; see also Frank v. Mangum, 237 U.S. 309, 330-32 (1915) (discussing impact of 1867 habeas corpus act's jettisoning of "face of the record" limitation); cf. supra notes 338-342, 363-369 and accompanying text (pre-1867 practice). 
sible to widen this jurisdiction." 381

Congress' desire to save Reconstruction from judicial invalidation in the famous Ex parte McCardle ${ }^{\mathbf{3 8 2}}$ affair prompted its 1868-1885 withdrawal of the Supreme Court's jurisdiction under the 1867 habeas corpus provision. ${ }^{383}$ Still, the Court's few initial interpretations of the provision around that period confirmed the wide range of claims and broad scope of review available under the provision. ${ }^{384}$ The provision's breadth also is confirmed by its (sparse) legislative history, ${ }^{385}$ the lower federal courts' early interpretations of it-as having:

clothed the district and circuit court judges of the United States with power to annul the criminal processes of the states, to reverse and set aside by habeas corpus the criminal judgments of the state courts, to pass finally and conclusively upon the validity of the criminal codes, the police regulations, and even the constitutions of the states ${ }^{386}$

-and the broader historical context of the Reconstruction Congress' reconstruction of federal judicial power. ${ }^{387}$

The clincher, though, is a point inexplicably iguored by the 1867 provision's historiography, namely, the immediate statutory contextCongress' February 5, 1867, simultaneous expansion of all three modes of reviewing state court determinations of federal questions in criminal cases. Taken together, the writ of error, removal, and habeas corpus provisions adopted that day leave little doubt as to Congress' goal. Article III defines the maximum constitutional extent of jurisdiction with which Congress may invest the federal courts on review of state court determinations of federal questions. The writ of error, removal, and habeas corpus provisions all used language tracking the same constitutional maximum to ensure enforcement in actions "begun in the courts of the States" 388 of the myriad of constitutional provisions and federal

381. Ex parte McCardle I, 73 U.S. (6 Wall.) 318, 325-26 (1867) (emphasis added). 382. 74 U.S. (7 Wall.) 506 (1868).

383. See Act of March 27, 1868, ch. 34, 15 Stat. 44, repealed by Act of March 3 , 1885 , ch. 353, 23 Stat. 437.

384. See Yick Wo v. Hopkins, 118 U.S. 356, 366, 373-74 (1886); Ex parte Royall, 117 U.S. 241, 247-53 (1886); Ex parte Tom Tong, 108 U.S. 556, 560 (1883); Ex parte Yerger, 75 U.S. (8 Wall.) 85, 106 (1868); Ex parte Bridges, 4 F. Cas. 98, 106 (N.D. Ga. 1875) (No. 1,862) (Bradley, Cir. Justice).

385. See Cong. Globe, 39th Cong., 1st Sess. 4151 (1866) (Rep. Lawrence) (habeas corpus provision is designed to "enforce the liberty of all persons . . . . It is a bill of the largest liberty, ... [not] restrain[ing] the writ of habeas corpus at all"); id. at 4229 (Sen. Trumbull).

386. Seymour D. Thompson, Abuses of the Writ of Habeas Corpus, 6 A.B.A. Rep. 243, 260-63 (1883); see also Seymour D. Thompson, Annotation, 18 F. 68, 81-86 (1883) (comprehensive review of the 1867-1883 habeas corpus cases in the lower federal courts).

387. See William M. Wiecek, The Reconstruction of Federal Judicial Power 1863-1875, 13 Am. J. Legal Hist. 333, 342-48 (1969).

388. Whitten v. Tomlinson, 160 U.S. 231.238 (1895). 
laws just then taking effect. Whatever ambiguities one might endeavor to read into the words of the habeas corpus portion of the second Act of February 5, 1867, no one has ever suggested that the almost identical words in the writ-of-error portion of the same Act permit anything less than plenary appellate review of alleged violations of "any title, right, privilege, or immunity . . . claimed under the constitution, or any treaty or statute of ... the United States."389 Through all three modes of review, Congress sought to assure prisoners of one full opportunity to enforce their newly given national rights in a national court, whether via expanded writ of error review on appeal in the Supreme Court, orlest the state courts' expected systematic resistance negate rights before writ of error remedies matured-via the extension to all prisoners of full-fledged, pre-writ-of-error habeas corpus and removal protections.

\section{E. Post-Reconstruction Limitations on Removal and Habeas Corpus Review}

1. Federal Prisoner Habeas Corpus. - Congress' 1874 adoption of the Revised Statutes united all pre-existing habeas corpus legislation in one set of sections. ${ }^{390}$ This revision encouraged federal prisoners, who technically had access to the Supreme Court under only the 1789 Act, ${ }^{391}$ to rely as well-with the Court's tacit acquiescence-on portions of the revised statutes derived from the 1867 Act. Federal prisoner access to the 1867 Act's grant of authority over constitutional claims and claims not visible on the face of the record ${ }^{392}$ thus ushered in the Golden Age of federal prisoner habeas corpus review. This trend lasted until 1891, when the onset of federal prisoner writs of error as of right largely superseded habeas corpus review. ${ }^{393}$

The Court's treatment of the federal prisoner habeas corpus cases during this period paralleled that in the 1789-1874 period, although here the larger number of cases provided a much clearer picture of the Court's inclinations and particularly of its location of the fundamentalnonfundamental line. The Court continued to hold itself out as addressing claims questioning not only the detaining court's jurisdiction but also, and distinctly, the "lawfulness" of the detaining court's actions, its "authority to give the judgment it did," and whether it acted

389. Act of Feb. 5,1867 , ch. $28, \S 2,14$ Stat. $385,386$.

390. See Act of June 22,1874, ch. $13, \S \S 755-766$ (originally codified as Rev. Stat. $\S \S 751-766)$.

391. See supra notes 382-383 and accompanying text (Congress' withdrawal of the Court's jurisdiction under the 1867 act in the Ex parte McCardle affair).

392. Early references to claims arising under the Constitution include Ex parte Crow Dog, 109 U.S. 556, 572 (1883); Ex parte Siebold, 100 U.S. 371, 374 (1879); Ex parte Jackson, 96 U.S. 727, 728 (1877). Early forays beyond the face of the record include Ex parte Clarke, 100 U.S. 399, 401 (1879); Ex parte Virginia, 100 U.S. 339, 343 (1879); Ex parte Jackson, 96 U.S. at 736-37 (dicta). But see ln re Snow, 120 U.S. 274, 281, 286 (1887); Ex parte Bigelow, 113 U.S. 328, 331 (1885) (emphasizing need for cognizable violations to be visible from record).

393. See infra notes $453-459$ and accompanying text. 
"beyond the powers conferred upon it."394 During this period, moreover, the line between lack of jurisdiction and lack of constitutionality almost entirely blurred, as when the Court held that a "sentence given was beyond the jurisdiction of the court, because it was against an express provision of the Constitution, which bounds and limits all jurisdiction."395 In other instances, the Court went directly to the constitutional point, enforcing "the positive and restrictive language of the great fundamental instrument by which the government is organized" $\$ 96$ and, through Justice Bradley, rejecting any distinction between "a conviction and punishment under an unconstitutional law" and "an unconstitutional conviction and punishment under a valid law."397

What the Court did during this period was to award habeas corpus review and, when merited, relief on claims that a penal statute or an action by the detaining court or official violated the prisoner's First, ${ }^{398}$ Fourth, ${ }^{399}$ Fifth, ${ }^{400}$ or Sixth ${ }^{401}$ Amendment rights, Eleventh Amendment or other constitutional federalism principles, ${ }^{402}$ or an applicable

394. Ex parte Yerger, 75 U.S. (8 Wall.) 85, 99 (1868); accord In re Bonner, 151 U.S. 242, 256 (1893); Nielsen, Petitioner, 131 U.S. 176, 184 (1889); Ex parte Parks, 93 U.S. 18, 23 (1876); see also In re Mills, 135 U.S. 263, 265-69 (1890) (review justified "[i]f it appears . . . apart from any questions as to jurisdiction . . . , detention ... is in violation of the laws of the United States" (emphasis added)); Ex parte Wilson, 114 U.S. $417,420-21$ (1885) (whether "the sentence exceeds the jurisdiction of th[e] court or there is no authority to hold him under the sentence" is a question to be addressed by the Court on habeas corpus).

395. Nielsen, Petitioner, 131 U.S. at 185; see also In re Bonner, 151 U.S. at 257 (equating "jurisdiction to render a particular judgment" with "keep[ing] within the limitations prescribed by the law, customary or statutory" which in turn is equated, e.g., with not taking action that the Constitution "specifically prescribe[s]"); Ex parte Wilson, 114 U.S. at 422 ("[I]f the crime of which the petitioner was accused was an infamous crime, within the meaning of the Fifth Amendment of the Constitution, no court of the United States had jurisdiction to try . . . him except upon . . . indictment by a grand jury."').

396. Ex parte Bain, 121 U.S. 1, 6 (1887)

397. Nielsen, Petitioner, 131 U.S. at 183; accord Ex parte Terry, 128 U.S. 289, 301 (1888); Callan v. Wilson, 127 U.S. 540, 541 (1888).

398. See, e.g., Davis v. Beason, 133 U.S. 333, 342-45 (1890) (free exercise claim); Ex parte Curtis, 106 U.S. 371, 372-73 (1882) (reviewing law forbidding political activity by federal employees); Ex parte Jackson, 96 U.S. 727, 736-37 (1877) (free press claim).

399. See, e.g., Ex parte Jackson, 96 U.S. at 733 (illegal search claim).

400. Decisions granting relief include Counselman v. Hitchcock, 142 U.S. 547, 585 (1892) (self-incrimination); Nielsen, Petitioner, 131 U.S. at 188 (double jeopardy); Ex parte Bain, 121 U.S. at 5-6, 12-13 (right to indictment); Ex parte Wilson, 114 U.S. at 422-26 (same). Decisions granting review but denying relief include Ex parte Terry, 128 U.S. at 311-14 (due process claim of inadequate notice and violation of right to be present when convicted of contempt); In re Coy, 127 U.S. 731, 753-55 (1888) (due process claim that penal statutes must require proof of intent).

401. Decisions granting relief include In re Bonner, 151 U.S. 242, 257-59 (1893) (jury clause); Horner v. United States, 143 U.S. 207, 213-14 (1892) (trial in district in which offense occurred); Callan v. Wilson, 127 U.S. at 549-57 (same).

402. See, e.g., In re Ayers, 123 U.S. 443, 485-87, 507-08 (1887) (unlawful contempt conviction for violating injunction that offended Eleventh Amendment); Ex 
federal statute. ${ }^{403}$ Faced with a parade of claims that the detaining court acted without subject matter jurisdiction by convicting the petitioner of conduct that federal law did not prohibit, the Court also found it necessary to draw a line separating these uniformly "jurisdictional" claims into ones that were and ones that were not cognizable. ${ }^{404}$ The Court's distinction neatly modeled its more general important-unimportant line: the Court would decide on habeas corpus whether entire broad "classes" of conduct fell within the court's jurisdiction under a penal statute-whether, for example, actions occurring outside a courtroom could constitute contempt, ${ }^{405}$ or whether different classes of conspiracies fell within a penal statute ${ }^{406}$ _but would not decide whether conduct falling within "a well defined class of offences" over which a criminal statute generally gave the court jurisdiction actually fit within the particular elements of the statutorily defined crime.407 When the Court denied review it did so on manifestly unimportant, typically sui generis claims-whether, for example, the indictment was "defective in form" or was pleaded with sufficient specificity, ${ }^{408}$ the evidence was sufficient to convict, ${ }^{409}$ or the trial court's allocution at sentencing contained a "technical defect." 410 As to claims the Court considered, its

parte Rowland, 104 U.S. 604, 616-18 (1881) (unlawful contempt conviction for violating injunction requiring state officials to act outside their statutory powers); Ex parte Siebold, 100 U.S. 371, 374-77 (1879) (reviewing but denying relief on claim that federal conviction of state officials for actions in pursuance of state law is unconstitutional).

403. See, e.g., In re Mills, 135 U.S. 263, 269-70 (1890) (violation of statute reserving penitentiary for individuals with sentences greater than one year); Ex parte Wilson, 114 U.S. at 422 (alleged violation of statutory right to indictment); Ex parte Crow Dog, 109 U.S. 556, 571-72 (1883) (violation of statutory exemption for intratribal crimes).

404. See In re Coy, 127 U.S. at 755; see also In re Sawyer, 124 U.S. 200, 220-21 (1888) (denying review of jurisdictional insufficient-amount-in-controversy claim).

405. See Cuddy, Petitioner, 131 U.S. 280, 284-86 (1889).

406. See Ex parte Yarbrough, 110 U.S. 651, 657 (1884); see also Ex parte Virginia, 100 U.S. 339, 346-49 (1879) (whether state judge may be prosecuted under federal statute prohibiting discrimination in jury selection).

407. In re Coy, 127 U.S. at 758; accord In re Bonner, 151 U.S. 242, 257 (1893). Compare In re Mayfield, 141 U.S. 107, 112-16 (1891) (reviewing whether victimless crimes by Indians should be treated under statute proscribing certain acts by one Indian against another or by statute proscribing certain acts by Indian against non-indian); In re Coy, 127 U.S. at 755 (reviewing question whether federal penal statute required proof of intent) with Ex parte Parks, 93 U.S. 18, 23 (1876) (refusing to review claim that document on which petitioner forged bankruptcy official's signature fell outside proscription of federal statute forbidding forgery of certain documents in course of bankruptcy proceedings).

408. See, e.g., In re Coy, 127 U.S. at 759; Ex parte Yarbrough, 110 U.S. at 654.

409. See, e.g., In re Wight, 134 U.S. 136, 148-49 (1890); Ex parte Carll, 106 U.S. 521,523 (1882).

410. See, e.g., Ex parte Wilson, 114 U.S. 417, 428-29 (1885). 
review was de novo on the law, ${ }^{411}$ deferential on the facts. ${ }^{412}$

With access to federal question review as wide as permitted by the Constitution, and with no available alternative mode of federal appellate review as of right, federal prisoner habeas corpus was in its heyday in the 1874-1890 period. Grants of review outstripped denials by a ratio of about four to one, and grants of relief occurred in over a third of the cases. ${ }^{413}$

2. State-Prisoner Removal and Habeas Corpus. - On the state-prisoner front, the Reconstruction-era consensus that, although available, writs of error were systematically inadequate, and that other modes of review accordingly were necessary, began to fade as Reconstruction ended. In an 1879 decision, Virginia $v$. Rives, ${ }^{414}$ the Supreme Court interpreted the post-war federal question removal statutes narrowly, ending their availability as a meaningful method of securing review and expressly relegating litigants to their state and federal writ-of-error remedies. ${ }^{415}$

Beginning in 1885, Congress and the Court jointly undertook a parallel deconstruction of habeas corpus. That year, Congress repealed the McCardle act's restriction on the Court's appellate jurisdiction under the 1867 statute. ${ }^{416}$ Because the 1874 codification had implicitly made the 1867 Act's cognizable claims and admissible evidence procedures available to federal prisoners in the Supreme Court, the restoration of jurisdiction simply extended the same type of review to state prisoners.

Although apparently expanding habeas corpus jurisdiction, Congress intended its 1885 action as something of a limitation. At the time, Congress had before it a number of proposals to repeal the 1867 habeas corpus law entirely or at least "to curtail and restrain to a certain extent the powers assumed by the Federal judges under the act ...."417 Fearful that " $[t]$ he special causes which were deemed to suffice to make the act of 1867 necessary"- the inability of African Americans "to get fair and impartial justice at the hands of local tribunals"- "may exist yet to some extent," Congress decided for the time being "to do no more than to recommend the restoration of the right of appeals to the Supreme Court."418 Through this mechanism, Congress assured that any "overthrow of the final judgments of the State courts of general jurisdiction, by the inferior Federal judges, . . . thus making them a court of errors over the highest tribunals of the States,"

411. See decisions cited supra notes 398-403, 405-406.

412. See, e.g., Cuddy, Petitioner, 131 U.S. 280, 286 (1889); Savin, Petitioner, 131 U.S. 267, 276 (1889); Ex parte Terry, 128 U.S. 289, 299-300, 305 (1888).

413. See decisions cited supra notes 394-412.

414. 100 U.S. 313 (1879).

415. See id. at 319,322 .

416. See Act of March 3, 1885, ch. 353, 23 Stat. 437.

417. H.R. Rep. No. 730, 48th Cong., 1st Sess., at 5 (1884).

418. 1d. at 3,5 . 
would not "be final" and instead could occur only with the concurrence of the Supreme Court. ${ }^{419}$ In addition, however, while acknowledging the need to "extend to [emancipated African Americans] as far as possible under the Constitution, the protection of the Federal courts," Congress also invited the Supreme Court, "[w]ith this right of appeal restored [to define] the true extent of the act of I867, and the true limits of the jurisdiction of the Federal courts and judges under [the act]," so that it could "then be seen whether further legislation is necessary." 420

Ex parte Royall, ${ }^{421}$ the Court's first state-prisoner habeas corpus decision under the 1885 Act, did indeed identify "the true extent of the act of 1867." "The grant . . . of jurisdiction to issue writs of habeas corpus," Justice Harlan concluded for the Court, "is in language as broad as could be well employed." 422 On coguizability, this meant "that it was the purpose of Congress to invest the courts of the Union ... with power ... to restore to liberty any person ... who is held in custody, by whatever authority, in violation of the Constitution of the United States." 423 A contrary state determination, the Court continued, expressly addressing the standard of review, "cannot affect the question, of the power or jurisdiction of the Circuit Court to inquire into the cause of his commitment, and to discharge [the prisoner] if he be restrained of his liberty in violation of the Constitution." 424

Having held (by reversing the lower court's contrary conclusion) that Congress left the federal courts with no choice but to review all constitutional and other federal law claims arising in state criminal courts, Justice Harlan then reached Royall's more famous conclusion that the federal courts do have "discretion" as to the "time and mode" of that review. ${ }^{425}$ Heeding Congress' invitation to see that "further legislation [was not] necessary"- - thus giving the Court's actions more the feel of a delegated judicial rulemaking than the fiat traditionally assumed-and also heeding Congress' desire that the Court itself, and not "the inferior Federal judges," be the statutorily mandated "court of errors over the highest tribunals of the States," Justice Harlan identified the preferred "mode" of federal review as its own "writ of error from the highest court of the State."426 That preference as to "mode"

419. 1d. at 5 .

420. Id. at 3, 6 (emphasis added).

421. 117 U.S. 241 (1886).

422. Id. at 247.

423. Id. at 248 .

424. Id. at 249; accord In re Ah Fong, 1 F. Cas. 213, 215 (C.C.D. Cal. 1874) (No. 102) (Field, Cir. J.) ("The decision of . . . the supreme court of the state, although entitled to great respect and consideration from the acknowledged ability and learning of the[ ] judges is not binding upon this court.").

425. Ex parte Royall, 117 U.S. at 251 (emphasis added).

426. Id. at 253. Practicing what it preached, the Court in fact gave Royall his day in court-and granted him constitutional relief-on his writ of error to the state courts, which the Supreme Court heard simultaneously with and decided a month earlier tban 
dictated an additional preference as to "timing," namely-as the writ of error statute required ${ }^{427}$ - that federal review wait until "the State court[s] shall have finally acted upon the case." 428 By preference, that is, the Court simply substituted its own de novo review of constitutional claims, under section 2 of the February 5, 1867 Act, for like review by lower federal courts under section 1.

Probably spurred on by an alarming bulge in the Court's habeas corpus docket-from two to four cases a year during the preceding decade to at least fourteen cases in 1890 and eight in $1891^{429}$ - the Court transformed what was announced in Royall as a discretionary rule of preference ${ }^{430}$ into a near-mandatory rule of practice. In the 1893 case of In re Frederich, 431 the Court announced that state prisoners henceforth would be left to their writ of error remedy. ${ }^{432}$ In New York $v$. Eno, ${ }^{433}$ the next year, the Court made the concomitant ${ }^{434}$ exhaustionof-state-remedies doctrine mandatory. ${ }^{435}$ And in Tinsley $v$. Anderson ${ }^{436}$ in 1898 , the Court made clear that the writ of error was exclusive. ${ }^{437}$ From the mid-1890s onward, therefore, state prisoners were precluded from receiving subsequent federal consideration if they either sought

Royall's habeas corpus appeal presenting the same claims. See Royall v. Virginia, 116 U.S. 572 (1886).

427. See supra note 337 and accompanying text.

428. Ex parte Royall, 117 U.S. at 253.

429. See the 1890 and 1891 cases cited infra notes $430,437-438,446-448,452$.

430. See Ex parte Royall, 117 U.S. at 252-53. Contributing substantially to the 1890-1891 bulge, the Court often ignored the exhaustion rules prior to 1892, but almost never afterwards. See, e.g., In re Rahrer, 140 U.S. 545 (1891); Crowley v. Christensen, 137 U.S. 86 (1890); Minnesota v. Barber, 136 U.S. 313 (1890); Savage, Petitioner, 134 U.S. 176 (1890); Ex parte Harding, 120 U.S. 782 (1887); Yick Wo v. Hopkins, 118 U.S. 356 (1886).

431. 149 U.S. 70 (1893).

432. See id. at 77-78; see, e.g., Baker v. Grice, 169 U.S. 284, 290-91 (1898); In re Eckart, 166 U.S. 481, 484-85 (1897); In re Belt, 159 U.S. 95, 100 (1895) ("Ordinarily the writ will not lie where there is a remedy by writ of error or appeal."); Andrews v. Swartz, 156 U.S. 272, 276 (1895); In re Chapman, 156 U.S. 211, 217-18 (1895); Pepke v. Cronan, 155 U.S. 100, 101 (1894).

433. 155 U.S. 89 (1894).

434. Suggesting that the main purpose of requiring exhaustion of state remedies was to satisfy the prerequisite to writ of error review are, e.g., Urquhart v. Brown, 205 U.S. 179, 181-83 (1907); United States ex rel. Drury v. Lewis, 200 U.S. 1, 6-7 (1906); Davis v. Burke, 179 U.S. 399, 401-02 (1900).

435. See New York v. Eno, 155 U.S. at 96-98; United States ex rel. Drury v. Lewis, 200 U.S. at 6-7; Minnesota v. Brundage, 180 U.S. 499, 500-01, 503, 505 (1901).

436. 171 U.S. 101 (1898).

437. See id. at 104-05; see also United States ex rel. Kennedy v. Tyler, 269 U.S. 13, 17 (1925); Reid v. Jones, 187 U.S. 153, 154 (1902); Fitts v. McGhee, 172 U.S. 516, 533 (1899). Another factor contributing to the 1890-1891 bulge in the Court's habeas corpus case load was that, prior to 1892 (but not afterwards), the Court occasionally granted habeas corpus review of claims previously rejected on writ of error. See, e.g., McElvaine v. Brush, 142 U.S. 155, 157-60 (1891); In re Wilson, 140 U.S. 575, 583-84 (1891); In re Duncan, 139 U.S. 449, 449-50 (1891); In re Converse, 137 U.S. 624, 624-25 (1891). 
writ of error review or waived it (for example, by waiving the state appeals that had to be exhausted in order to permit direct Supreme Court review). ${ }^{438}$ Pace Bator yet again, these rules applied without distinction to claims challenging the detaining court's jurisdiction, a penal statute's constitutionality, or the lawfulness of a sentence. ${ }^{439}$

The Court did not reject habeas corpus review, however, but only replaced it whenever possible with its own review on the merits as of right. ${ }^{440}$ Clearly revealing the commensurability and the substitutability of writ of error and habeas corpus review ${ }^{441}$ are the three exceptional situations in which the Court regularly afforded habeas corpus review-when (1) a writ of error remedy was not meaningfully available, ${ }^{442}$ (2) exhausting State remedies prefatory to federal review would unduly delay federal review, ${ }^{443}$ or (3) state remedies were exhausted before the case reached the Supreme Court so that dismissal in preference for a writ of error would simply require the meaningless gesture of substituting writ of error papers for the habeas corpus papers already before the Court. ${ }^{444}$

As the above analysis of Whitten $v$. Tomlinson reveals, ${ }^{445}$ in the significant number of cases during the period in which habeas corpus review remained available, the Court continued to apply its longstanding rules distinguishing fundamental-including all constitutional ${ }^{446}-$

438. See, e.g., Ex parte Spencer, 228 U.S. 652, 660-61 (1913); Glasgow v. Moyer, 225 U.S. 420, 429-30 (1912); In re Wood, 140 U.S. 278, 286-87, 289-90 (1891).

439. See, e.g., Knewel v. Egan, 268 U.S. 442, 445-46 (1925) (jurisdictional and unconstitutional-statute claim); Minnesota v. Brundage, 180 U.S. at 500-01 (unconstitutional-statute claim); Tinsley v. Anderson, 171 U.S. 101, 104-06 (1898) (jurisdictional claim); In re Eckart, 166 U.S. 481, 483-85 (1897) (same); In re Belt, 159 U.S. 95, 99-100 (1895) (unconstitutional-statute claims not an exception to rule preferring writ of error review).

440. The Court justified its preference for writ of error review on the ground that the writ of error was available as of right. See, e.g., Urquhart v. Brown, 205 U.S. 179, 182-83 (1907); Markuson v. Boucher, 175 U.S. 184, 185-87 (1899).

441. See In re Chapman, 156 U.S. 211, 216-18 (1895) (characterizing habeas corpus and direct review as alternative "modes" of "appellate jurisdiction").

442. See, e.g., Pettibone v. Nichols, 203 U.S. 192, 202 (1906) (interlocutory extradition proceedings); Felts v. Murphy, 201 U.S. 123, 128-30 (1906) (petitioner could not afford to pay for transcript necessary to permit exhaustion of state, then writof-error remedies); in re Chapman, 156 U.S. at 216-18 (if, after exhaustion, Court deemed that writ of error statute did not apply to District of Columbia courts, then habeas corpus review would be permitted).

443. See, e.g., Storti v. Massachusetts, 183 U.S. 138, 142-43 (1901) (apparent need for immediate review of impending execution); Baker v. Grice, 169 U.S. 284, 293 (1878) (dicta).

444. See, e.g., Rogers v. Peck, 199 U.S. 425, 434-36 (1905); Davis v. Burke, 179 U.S. $399,401-02$ (1900).

445. See supra notes 300-304, 319-323 and accompanying text.

446. See, e.g., Pettibone v. Nichols, 203 U.S. at 201; Felts v. Murphy, 201 U.S. at 130; Rogers v. Peck, 199 U.S. at 433-34, 435 ("When a prisoner is in jail he may be released upon habeas corpus when held in violation of his constitutional rights"); see also ln re Converse, 137 U.S. 624, 624-25, 631 (1891) ("an unconstitutional conviction 
claims, which were cognizable, ${ }^{447}$ from nonfundamental and state law claims, which were not, ${ }^{448}$ and affording de novo review of legal, ${ }^{449}$ but little or no review of factual, ${ }^{450}$ determinations. Exemplifying the cognizability of constitutional claims on undisputed facts is the Court's grant of relief in Yick Wo $v$. Hopkins; ${ }^{451}$ exemplifying the lack of review of state court factual determinations is the Court's denial of review of the jury discrimination claim in In re Wood. ${ }^{452}$

\section{F. Late Nineteenth Century and Early Twentieth Century Revisions of the Supreme Court's Writ of Error Jurisdiction}

1. Federal-Prisoner Appeals and Habeas Corpus. - As 1 have already noted, Congress dramatically rearranged the appellate map in the Evarts Act of 1891, for the first time affording federal criminal defendants writ of error review in the Supreme Court. ${ }^{453}$ Then, in 1897, Congress

and punishment under a valid law would be as violative of a person's constitutional rights as a conviction and punishment under an unconstitutional law"); supra notes 421-423, and accompanying text.

447. Among the fundamental claims litigated during this period were the applicability to the states of the Fifth, Sixth, and Eighth Amendments (the Court's answer uniformly being negative), see, e.g., Davis v. Burke, 179 U.S. at 401-04; McElvaine v. Brush, 142 U.S. 155, 158-59 (1891); Ex parte Harding, 120 U.S. 782, 783-84 (1887); the scope of the Fourteenth Amendment due process protection, see, e.g., Valentina v. Mercer, 201 U.S. 131, 132, 138-39 (1906) (right to instruction on selfdefense and voluntary manslaughter); Felts v. Murphy, 201 U.S. at 124-26, 129-30 (constitutionality of convicting deaf prisoner in proceedings he could not understand); Andrews v. Swartz, 156 U.S. 272, 275 (1895) (right to appeal in capital cases); Bergemann v. Backer, 157 U.S. at 656-58 (right to notice in indictment of degree of murder being charged); In re Converse, 137 U.S. at 628 (constitutionality of procedures used to take guilty plea); the scope of the Fourteenth Amendment right to equal protection, see, e.g., Crowley v. Christensen, 137 U.S. 86, 92-94 (1890); and ex post facto claims, see, e.g., Medley, Petitioner, 134 U.S. 160, 171-73 (1890).

448. See, e.g., Storti v. Massachusetts, 183 U.S. 138, 138-39, 142 (1901) (governor's power to stay execution under state law); In re Eckart, 166 U.S. 481, 482 (1897) (sufficiency of form and legal meaning of indictment under state law); Kohl v. Lehlback, 160 U.S. 293, 299-300 (1895) (propriety under state law of seating alien on grand jury); In re Jugiro, 140 U.S. 291, 292-93, 297 (1891) (variance between indictment (alleging stab wound in breast) and proof (showing stab wound in neck)).

449. See cases cited supra notes $442-444,446$.

450. See, e.g., Crossley v. Califoruia, 168 U.S. 640, 642 (1898) (sufficiency of evidence); In re Jugiro, 140 U.S. at 297-98 (finding that no jury discrimination occurred); In re Converse, 137 U.S. at 631 (finding that prisoner understood he was pleading guilty to felony and not, as he claimed, to a misdemeanor).

451. 118 U.S. 356, 374 (1886); see supra notes $265-268$ and accompanying text.

452. 140 U.S. 278, 285-87 (1891). Pace Bator and Justice Thomas, Wood is not a case in which the Court treated the state court's judgment as res judicala, cf. supra notes 281-284 and accompanying text, but rather one in which it treated as unreviewable the state court's factual determination that no discrimination in the selection of the jury had occurred, see In re Wood, 140 U.S. at 285-86, precisely the same treatment the Court at the time accorded the same type of claim on direct review, see, e.g., Thomas v. Texas, 212 U.S. 278, 281-82 (1909).

453. See Act of Mar. 3, 1891 , ch. 517, $\S 5,26$ Stat. 826, 827-28. Congress gave 
routed appeals as of right in noncapital cases (and in 1911 in capital cases) through the newly created Circuit Courts of Appeals to the Supreme Court on certiorari. ${ }^{454}$ Drawing an analogy to the exhaustion of state remedies doctrine, the Court immediately created an exhaustion of federal appellate remedies doctrine, requiring resort to direct review in the Supreme Court (and, after 1897, in the courts of appeals) on writ of error when meaningfully available. ${ }^{455}$ Judgments attained on writ of error in the Court precluded subsequent habeas corpus review, ${ }^{456}$ while the failure to appeal waived claims that could have been appealed. ${ }^{457}$ In cases in which habeas corpus remained available for lack of meaningful appellate remedies, ${ }^{458}$ exhaustion of lower federal court habeas corpus remedies was required before coming to the Supreme Court. 459 The Golden Age of federal prisoner habeas corpus consideration had passed.

2. Expanded Fact Review. - In 1912, the Supreme Court substantially expanded the scope of its appellate review of federal questions arising in the state courts by inventing two doctrines that let it review de novo questions previously denominated as "factual" and, as such, given no review. ${ }^{460}$ Henceforth, the Supreme Court would independently review findings of facts (1) " "where a Federal right has been denied as the result of a finding shown by the record to be without evidence to support it," " or (2) " "where a conclusion of law as to a Federal right and a finding of fact are so intermingled as to make it necessary, in order to pass upon the Federal question to analyze the facts." "461

capital prisoners a right of appeal two years earlier. Act of Feb. 6, 1889, ch. 113, §6, 25 Stat. $655,656$.

454. See Act of Mar. 3, 1911, ch. 231, §§ 128, 238, 36 Stat. 1087, 1133-34, 1157; Act of Jan. 20, 1897, ch. 68, 29 Stat. 492.

455. See, e.g., In re Lincoln, 202 U.S. 178, 182 (1906) ("[T]he ordinary procedure for the correction of errors in criminal cases is by writ of error, and that method should be pursued unless there be special circumstances calling for a departure therefrom. ..."); Riggins v. United States, 199 U.S. 547, 548-50 (1905); In re Lancaster, 137 U.S. 393, 395 (1890).

456. See cases cited supra notes 436,437 .

457. See, e.g., Craig v. Hecht, 263 U.S. 255, 277 (1923); Glasgow v. Moyer, 225 U.S. 420, 429-30 (1912); Toy Toy v. Hopkins, 212 U.S. 542, 548-49 (1909) (waiver for failure to appeal; no exception for jurisdictional claims).

458. See, e.g., Ex parte Hudgings, 249 U.S. 378, 379-80, 384 (1919); Dimmick v. Tompkins, 194 U.S. 540, 541, 546 (1904) (challenge to conditions of confinement); In re Schneider, 148 U.S. 162, 166 (1893) (no writ of error available to District of Columbia courts).

459. See, e.g., Ex parte Hudgings, 249 U.S. at 379-80, 384; In re Huntington, 137 U.S. 63, 64 (1890); Ex parte Mirzan, 119 U.S. 584, 586 (1887).

460. Invented seems appropriate given the abruptness with which the doctrines arose in 1912 and the paucity of antecedents. See, e.g., Norris v. Alabama, 294 U.S. 587, 589-90 (1935) (tracing doctrines to 1912 decisions). So powerful were the new doctrines that they superseded the Seventh Amendment's immunization of jury findings from de novo review. See, e.g., Thomas v. Arizona, 356 U.S. 390, 393 (1958); Ashcraft v. Tennessee, 322 U.S. 143, 147-48 (1944).

461. Robertson \& Kirkham, supra note $14, \S 108$, at 198-99 (footnotes omitted) 
For a time, the Court applied the two doctrines exclusively in civil cases, typically using them to review (and often to overturn) state court determinations that state or local business regulations did not interfere with contracts or impose confiscatory rates.62 Only in Fiske $v$. Kansas $^{463}$ in 1927 and in Norris v. Alabama ${ }^{464}$ in 1935 did the Court explicitly use the doctrines to expand the scope of its direct review of state criminal cases, ${ }^{465}$ although, as we will see, Justice Holmes presaged these developments in 1915.

From the beginning, the Court justified both doctrines on the ground that the questions affected were not "factual" at all but were "legal" questions masquerading as factual ones, and that preservation of the Court's power to settle the meaning of national law and rights required it to be able to look through the "factfinding" disguise. 466 Thus, as Professor Monaghan has shown with regard to the "mixed question" doctrine, there are certain "factual" concepts-the voluntariness of confessions, for example-that are so difficult to define once for all time and so dependent for their evolution on a constant progression of new fact situations, that giving lower courts unreviewable authority not only to find the historical facts but also to determine whether the facts satisfy the definition is tantamount to giving those courts the power to define the concept-and make the law. 467 Moreover, even when a legal rule turns on the existence of some more readily and permanently definable fact, the prior court's "finding" of that fact in the

quote Fiske v. Kansas, 274 U.S. 380, 385-86 (1927) and cite Cedar Rapids Gas Light Co. v. Cedar Rapids, 223 U.S. 655 (1912), and Creswill v. Knights of Pythias, 225 U.S. 246, 261 (1912), as originating the first exception, and cite Kansas City S. Ry. v. C.H. Albers Comm'n Co., 223 U.S. 573, 591 (1912), as originating the second. See supra note 15 (same doctrines applied to review of lower federal court factfinding).

462. See, e.g., Aetna Life Ins. Co. v. Dunken, 266 U.S. 389, 394 (1924); Truax v. Corrigan, 257 U.S. 312, 324-25 (1921); Ward v. Board of County Comm'rs, 253 U.S. 17, 22-23 (1920); New York \& Queens Gas Co. v. McCall, 245 U.S. 345, 348-49 (1917); Norfolk \& W. Ry. v. West Virginia, 236 U.S. 605, 609-10 (1915); Cedar Rapids Gas Light Co. v. Cedar Rapids, 223 U.S. at 668-69; Kansas City S. Ry. v. C.H. Albers Comm'n Co., 223 U.S. at 591-94.

463. 274 U.S. $380,385-86$ (1927).

464. 294 U.S. 587, 589-90 (1935) (reviewing de novo question whether state officials discriminated against blacks in composing jury venire); cf. In re Wood, 140 U.S. 278, 285-86 (1891) (discussed supra note 452 and accompanying text).

465. See, e.g., Chambers v. Florida, 309 U.S. 227, 228-29 (1940) (voluntariness of confession "determine[d] independently"); Pierre v. Louisiana, 306 U.S. 354, 358 (1939) (jury discrimination); Brown v. Mississippi, 297 U.S. 278, 286-87 (1936) (voluntariness of confession).

466. See, e.g., Gallegos v. Nebraska, 342 U.S. 55, 61 (1951); Norris v. Alabama, 294 U.S. at $\mathbf{5 9 0}$ (de novo review of mixed question required so that "appropriate enforcement of the federal right may be assured"; "[o]therwise, review by this Court would fail of its purpose in safegurarding constitutional rights"); Ward v. Board of County Comm'rs, 253 U.S. at 22; Kansas City S. Ry. v. C.H. Albers Comm'n Co., 223 U.S. at 591, 594.

467. See Miller v. Fenton, 474 U.S. 104, 113-18 (1985); Monaghan, supra note 12, at 261-62, 271-76. 
absence of any evidence suggests that the prior court's definition of that fact must differ from the reviewing court's-hence that the prior court made a mistake of law. 468

3. Certiorarification of Supreme Court Direct Review. - In 1914, after a quarter century of modest erosion in the Supreme Court's mandatory writ of error and appeal jurisdiction and accretion to its discretionary certiorari jurisdiction, ${ }^{\mathbf{4 6 9}}$ and of greater erosion in the number of cases actually granted plenary review on writ of error, ${ }^{470}$ Congress enacted the first in a series of laws that almost entirely replaced direct Supreme Court review as of right on writ of error with discretionary direct review on writ of certiorari. The 1914 law allowed litigants aggrieved by decisions of the state courts in favor of federal rights to seek review by certiorari. ${ }^{471}$ A 1916 law made review of state court decisions in favor of or against a claim of federal right reviewable only on certiorari, unless the party seeking review attacked the "authority" of the state or federal governments to act as opposed to the constitutionality of an action within the authority of the official actor. ${ }^{472}$ And a 1925 law located all requests for review within the Court's certiorari jurisdiction, save requests for review of state court decisions striking down federal or upholding state statutes under the Constitution. $\mathbf{4 7 3}$

4. State-Prisoner Habeas Corpus. - Given the Court's prior treatment of direct Supreme Court review as of right, when available, as a preferred alternative to habeas corpus, and, when not available, as a model for proceedings under the writ, the early twentieth century decrease in the as-of-right availability, and increase in the scope, of direct Supreme Court review should have expanded the use and widened the scope of habeas corpus review. And so it did in Frank v. Mangum ${ }^{44}$ in 1915 and, especially, in Moore v. Dempsey ${ }^{475}$ in 1923.

Frank and Moore are puzzles. On the basis of the plenary review afforded the petitioner's legal claims, Professor Bator considers Frank

468. See, e.g., Cox v. Louisiana, 379 U.S. 536, 545 n.8 (1965); Stein v. New York, 346 U.S. 156, 182 (1953).

469. See Judiciary Act of 1891 , ch. 517, § 6, 26 Stat. 826, 828 (limiting Supreme Court's review as of right of decisions of newly created Circuit Courts of Appeals to cases in which matter in dispute exceeded $\$ 1000$; other cases heard on certiorari); provisions cited supra note 454 and accompanying text.

470. See, e.g., Ex parte Frank, 235 U.S. 694 (1914) (mem.); In re Kemmler, 136 U.S. 436, 438 (1890); Spies v. Illinois, 123 U.S. 131, 164 (1887).

471. See Act of Dec. 23, 1914, ch. 2, 38 Stat. 790. Previously, the Supreme Court could not review such decisions at all.

472. See Act of Sept. 6, 1916, ch. 448, § 2, 39 Stat. 726.

473. See Act of Feb. 13, 1925, ch. 229, § 237, 43 Stat, 936, 937. In 1928, the Court renamed the residual right to review as of right an "appeal" rather than a "writ of error," although the confines of that right remained the same as in 1925. Act of Jan. 31, 1928, ch. 14, 45 Stat. 54; accord Hart \& Wechsler, 3d ed., supra note 241, at 501-03; supra note 51 .

474. 237 U.S. 309, 329-32 (1915).

475. 261 U.S. 86, 90-92 (1923). 
one of the great advances in the scope of the writ. ${ }^{476}$ Yet the outcome of the case-approving an apparently mob-terrorized jury's conviction and condemnation of a Jewish man for raping and murdering a young Christian woman-led Chief Judge Oakes recently to call Frank one of the Court's great failures of nerve, on a par with Dred Scott and Plessy. ${ }^{477}$ The outcome of Moore is easier to understand, but difficult to square with Frank. ${ }^{478}$

In both cases, the presence of a mob threatening the courtroom was admitted, and the evidence supporting the petitioners' allegations of mob influence on the judges and juries was substantial. ${ }^{479}$ In both cases, the trial courts under cooler circumstances denied new trial motions on the basis that the mobs' influence had not affected the proceedings. ${ }^{480}$ In both, the state supreme courts affirmed, finding, in effect, that the mobs had not influenced the verdicts.481 In both, the petitioners unsuccessfully sought direct review in the United States Supreme Court before seeking and being denied habeas corpus relief in the lower federal courts. ${ }^{482}$

On appeal from the denial of habeas corpus in both cases, the Supreme Court treated "the writ of habeas corpus [as available] . . . only in case the judgment under which the prisoner is detained is shown to be absolutely void."483 Although Frank ostensibly tied this concept to a "want of jurisdiction in the court that pronounced [the judgment]," it understood that concept to be dictated by the Due Process Clause as well as by the habeas corpus statute, and defined it to include cases in which jurisdiction "was lost in the course of the proceedings" through mob influence on the jury or other due process violations. ${ }^{484}$ In the end, the Court in both cases clearly and repeatedly said that all due process and constitutional claims were cognizable on habeas corpus. ${ }^{485}$ In both cases, the Court concluded that due process

476. See Bator, supra note 6 , at $484-87$.

477. See Violent Crime Control Act of 1991, Hearings Before the Senate Judiciary Comm., 102nd Cong., 1st Sess. 312 (1991) (testimony of Chief Judge Oakes). Frank almost certainly was innocent. See Wendell Rawls, Jr., After 69 Years of Silence, Lynching Victim Is Cleared, N.Y. Times, Mar. 8, 1982, at A12.

478. See supra text accompanying notes 271-274, 283-284 and accompanying text.

479. See Moore v. Dempsey, 261 U.S. at 87-90; Frank v. Mangum, 237 U.S. 309, 332-34 (1915).

480. See Moore v. Dempsey, 261 U.S. at 91-92; id. at 96-99 (McReynolds, J., dissenting); Frank v. Mangum, 237 U.S. at 333.

481. See Moore v. Dempsey, 261 U.S. at 91; Frank v. Mangum, 237 U.S. at 313-14.

482. See Moore v. Dempsey, 261 U.S. at 87; Moore v. Arkansas, 254 U.S. 630 (1920); Frank v. Mangum, 237 U.S. at 31 1, 317; Ex parte Frank, 235 U.S. 694 (1914). 483. Frank v. Mangum, 237 U.S. at 327; accord Moore v. Dempsey, 261 U.S. at 91-92.

484. Frank v. Mangum, 237 U.S. at 327; accord id. at 334-35; id. at 347 (Holmes, J., dissenting).

485. See id. at $326,328,330,331,335,345$ (habeas corpus lies to relieve petitioner 
also demanded a fair "corrective process" either at trial or on appeal in which to litigate a claim that trial by mob had occurred, and that habeas corpus was available to redress the absence of fair corrective process. ${ }^{486}$ And the Court found the same state corrective process in both cases-a new trial proceeding followed by an appeal, neither affected by a mob - which it ruled adequate in Frank ${ }^{487}$ and did not clearly rule inadequate in Moore. ${ }^{488}$

Three questions arise: First, and most puzzling, why did both decisions abandon the Court's practice of treating its direct review as preferred over and preclusive of later habeas corpus review? Second, why did the Court deny relief under the aggravated circumstances of Frank? Third, given that denial, why did the Court remand for further proceedings in Moore?

In Frank, the majority and dissent clearly describe both the exhaustion of state remedies doctrine and the exhaustion of Supreme Court remedies doctrine as only preliminary to, and not preclusive of, later federal habeas corpus review. 489 The Moore Court proceeded according to the same rule. The only evidence bearing on the Court's mysterious departure from its previously preclusive doctrine requiring exhaustion of Supreme Court review is (1) the Court's one-line summary memoranda reporting its denial of Frank's writ of error application and of the Moore petitioners' certiorari petition on direct review ${ }^{490}$ and (2) Justice Holmes' comment in dissent in Frank that he and Justice Hughes had voted to grant Frank's writ of error application and thereby to afford him plenary review rather than just a summary denial. 491

Sparse as they are, these data seem to me to solve the puzzle. Both exemplify the unofficial (in Frank) and then official (in Moore) "certiorarification" of direct Supreme Court review. In both cases, the Court's plenary review on habeas corpus seems to have responded to a recognition that, by then, the Court could not supply the plenary re-

"shown to have been deprived of any right guaranteed to him by the Fourteenth Amendment or any other provision of the Constitution or laws of the United States"); Moore, 261 U.S. at 87-88 ("question [is] whether their constitutional rights have been preserved").

486. See Frank v. Mangum, 237 U.S. at 335; Moore v. Dempsey, 261 U.S. at 91.

487. See Frank v. Mangum, 237 U.S. at 335-36.

488. See Moore v. Dempsey, 261 U.S. at 91-92.

489. See Frank v. Mangum, 237 U.S. at 328-29 ("[T]he writ in the absence of very special circumstances, ought not to be issued until the state prosecution has reached its conclusion, and not even then until the Federal questions arising upon the record have been brought before this court upon writ of error.") (emphasis added); id. at 348 (Holmes, J., dissenting).

490. See Moore v. Arkansas, 254 U.S. 630 (1920) (mem.); In re Frank, 235 U.S. 694

(1914) (mem.) (denying cert. in Frank v. State, 83 S.E. 645 (1914)).

491. See Frank v. Mangum, 237 U.S. at 346 (Holmes, J., dissenting). 
view as of right that previously had permitted a preference for its own direct review.

The answer the Frank Court gave to the second question was simple: the Georgia Supreme Court determination that the mob had not intimidated the jury was one of fact, hence beyond the Court's power to overturn unless tainted by an independent constitutional violation, namely, the denial of an adequate corrective procedure for litigating the mob-domination claim. 492 Because the state courts had provided such a procedure, no fair-process violation had occurred, and the factfinding stood.

On the way to stating this conclusion, the Court first rejected the argument that the state courts' legal determinations bound the court. Thus, although seeing logic in the view that state court determinations as to both law and fact ought to be "res judicata" in habeas corpus proceedings, Justice Pitney (pace Bator) rejected that view for lack of supporting precedent (except insofar as a prior court's factual determinations were concerned) and "in view of the impropriety of limiting in the least degree the authority of the United States in investigating an alleged violation by a state of the due process of law guaranteed by the Fourteenth Amendment." 493

Noting that the inapplicability of res judicata "does not mean that [the state] decision may be iguored or disregarded,"494 Justice Pitney then inserted perhaps the most fought-over passage in habeas corpus law. 495 Justice Pitney began by recognizing that a trial "in fact dominated by a mob so that the jury is intimidated and the trial judge yields" violates due process as long as the "state suppl[ies] no corrective process [and] carr[ies] into execution" the judgment produced thereby. ${ }^{496}$ Whether that in fact had happened here was the matter to which Justice Pitney turned, beginning with the decision of the Georgia Supreme Court which, "upon a full review, decided appellant's allegations of fact, so far as matters now material are concerned[,] to be unfounded."497 And it was just there, as well, that Justice Pitney's analysis ended-as he said in a passage that, fought over or not, could not be clearer:

[W]e hold that such a determination of the facts as was thus made by the court of last resort of Georgia respecting the alleged interference with the trial through disorder and manifestations of hostile sentiment cannot in this collateral inquiry be treated as a nullity, but must be taken as setting forth the truth of the matter, certainly until some reasonable ground is shown for an inference that the court which rendered it either was wanting

492. See id. at $335-36$ (majority opinion).

493. Id. at 334 .

494. Id.

495. See, e.g., Bator, supra note 6, at 484-87; Peller, supra note 191 , at 608-10.

496. Frank v. Mangum, 237 U.S. at 335 (emphasis added).

497. Id. (emphasis added). 
in jurisdiction, or at least erred in the exercise of its jurisdiction; and the mere assertion by the prisoner that the facts of the matter are other than the state court, upon investigation determined them to be, will not be deemed sufficient to raise an issue respecting the correctness of that determination . . . .498

A jury dominated by a mob cannot, without violating due process, adjudicate the defendant's guilt. And a judge dominated by a mob cannot, without also violating due process, vitiate the first violation by "finding" on the spot that no mob domination occurred. But an appellate court that was not even arguably threatened by the mob can vitiate the first violation by finding, "upon a full review," free of any independent due process violation, that "in point of fact" 499 no mob domination occurred.

For Justice Holmes in dissent, the problem was that the "whole structure" of the majority's decision turned on its characterizing as a matter of pure fact what he instead recognized as at least partly a matter of law. 500 In what for the next several decades was one of the germinal statements of the "mixed question" doctrine, 501 Justice Holmes wrote:

When the decision of the question of fact is so interwoven with the decision of the question of constitutional right that the one necessarily involves the other, the Federal court must examine the facts. Otherwise, the right will be a barren one. It is significant that the argument for the state does not go so far as to say that in no case would it be permissible, on the application for habeas corpus to override the findings of fact by the state courts. It would indeed be a most serious thing if this Court were so to hold, for we could not but regard it as a removal of what is perhaps the most important guaranty of the Federal Constitution. If, however, the argument stops short of this, the whole structure [of the majority opinion] built upon the state procedure and decisions falls to the ground. ${ }^{502}$

That, pace Peller, the Frank majority did not deny relief on the due process ground that mob rule at trial is permissible as long as the guilty verdict is affirmed on appeal should now be clear. What the state supreme court's decision instead provided was an unassailable "no mob influence" fact finding of the sort the judge at trial could not provide because he, too, may have succumbed to the mob. That, pace $\mathrm{Ba}-$ tor, the Court did not deny relief on the res judicata ground that, the state courts having fairly spoken, the federal courts were entirely bound

498. Id. at 335-36 (emphasis added).

499. Id. at 344 .

500. See id. at 348 (Holmes, J., dissenting).

501. See, e.g. Rogers v. Richmond, 365 U.S. 534, 546 (1961); Marsh v. Alabama, 326 U.S. 501, 510 (1946); United States v. Pink, 315 U.S. 203, 238 (1942).

502. Frank v. Mangum, 237 U.S. at 347-48 (Holmes, J., dissenting) (citing, e.g., Kansas City S. Ry. v. C.H. Albers Comm. Co., 223 U.S. 573, 59 I (1912)). 
also should be clear from the Court's express resolution not to "invoke the doctrine of res judicata." 503 The collection of doctrines on which both the Court and the dissent undertook to decide the case was neither due process nor habeas corpus doctrine, but, instead, familiar principles governing federal appellate review of a prior court's factual and mixed factual and legal determinations. Pitney looked backwards to the pre-1912 days in which fact review, of any sort, meant no review. Justice Holmes looked forward to the importation of the Court's mixed-question and no-evidence doctrines into the realm of personal, as well as economic, liberties.

That the principles over which Pitney and Holmes disagreed are more usually known as direct appeal, not habeas corpus, principles simply proves my point: following the certiorarification of the Court's direct appellate docket, the Court's inability to satisfy by itself the federal courts' statutory obligation to conduct review as of right, according to those principles, of the constitutionality of state detention thrust the obligation on the lower federal courts on habeas corpus. All that remained, therefore, was for the Court to finish the fight over the application of those principles to putative mixed questions of constitutional law and fact arising in the criminal setting.

And that is exactly what Justice Holmes did in his opinion for the Court in Moore. Remanding the case to the lower court to examine the dispositive "fact" of mob influence, in order to see whether there was an uncorrected "wrong" denying "the petitioners constitutional rights," Justice Holmes ordered that examination to proceed de novo: "We shall not say more concerning the corrective process afforded to the petitioner"-as, in Frank, a new trial and appeal proceeding504_ "than that it does not seem to us sufficient to allow a judge of the United States to escape the duty of examining the facts for himself when, if true as alleged, they make the trial absolutely void." 505

503. Frank v. Mangum, 237 U.S. at 334. Both the Peller and the Bator theses are even more forcefully refuted by the Court's treatment of Frank's second claim. Frank originally claimed that his right to attend his trial was violated when fear of the mob led him to absent himself from the courtroom during the announcement of the verdict. The state courts concluded that he waived any right-to-presence claim by failing to include it in his motion for a new trial. Frank countered by arguing that due process forbade treating the right to presence as waivable. The state courts disagreed. Far from treating the state court's determination of this entirely legal question as dispositive, the majority and the dissent both considered it de novo, and rejected it on the merits. See id. at 340-43; id. at 346 (Holmes, J., dissenting). The discrepancy between the Court's deferential review of the mob domination issue and its de novo review of the presence issue belies both the Peller thesis, which brooks no deference, and the Bator thesis, which brooks no de novo review of a question fairly, even if erroneously, adjudicated in the state courts.

504. See supra notes $480-481$ and accompanying text.

505. Moore v. Dempsey, 261 U.S. 86, 92 (1923). Justice Holmes clearly said what was to be done but not so clearly why. Two reasons appear: that, as Holmes argued in Frank, the mob influence question was sufficiently interwoven with law to require de novo 
From Royall to Frank and Frank to Moore, it was not habeas corpus or due process that changed, but rather federal question appellate review. That habeas corpus review on the merits suddenly re-emerged from the periphery was a function of the increasing unavailability of alternative review as of right in the Supreme Court. That the scope of federal habeas corpus review of mixed questions expanded so quickly and substantially after Frank was a function of the Court's expansion of its own direct review of fact-affected federal questions after 1912. That muscular review of partly factual questions reached criminal cases on habeas corpus before those on direct review is a function of both trends-as increasingly during the 1920s and afterwards, what federal question review of state criminal cases took place did so in the habeas corpus context. ${ }^{506}$

\section{G. Moore to Brown: Criminal Procedure Revolution and Direct Review Devolution}

Just as the Court's mixed question and allied fact review doctrines expanded the scope of review on habeas corpus between Frank and Moore, so did the Court's emerging Criminal Procedure Revolution expand the reach of the constitutional claims cognizable on habeas corpus in the thirty years between Moore and Brown - both trends impelled by the run-off from the Court to the lower federal courts of cases in which the Court's discretionary review was unavailable or denied.

On the federal prisoner side, the Court's recognition of a group of constitutional rights whose violation created exceptions to the otherwise preclusive exhaustion-of-appellate-remedies doctrine ${ }^{507}$ set off virtually a second Golden Age of federal-prisoner review. The Court soon recognized, for example, that prisoners denied their newly recognized right to counsel could not be blamed for failing to pursue timely and complete appeals; ${ }^{508}$ that prisoners coerced into pleading gnilty typi-

review; or that the Arkansas Supreme Court determination (little more than "that it could not say 'that [mob influence] must necessarily have been the case" ") did not settle the determinative question. Id. at 91; cf. Frank v. Mangum, 237 U.S. at 313-I4 (detailed state court factfindings).

506. See cases cited infra notes 508-5I4. With this devolution of review as of right from the Court to the lower federal courts came the question whether an initial federal habeas corpus proceeding precluded successive federal review, as did writ of error review in the Supreme Court. In Salinger v. Loisel, 265 U.S. 224, 23 I-32 (I924), decided the year after Moore, the Court ruled that prior habeas corpus consideration should have effect, but not quite a res judicata effect, on whether successive review was warranted. Accord Wong Doo v. United States, 265 U.S. 239, 241 (1924) (upholding denial of writ of habeas corpus as exercise of "sound judicial discretion," but declining to rely on "the inflexible doctrine of res judicata").

507. For general statements of the exhaustion of appellate remedies doctrine, see, e.g., Sunal v. Large, 332 U.S. 174, 177-78 (1947); Craig v. Hecht, 263 U.S. 255, 277 (1923); supra notes $455-457$ and accompanying text.

508. See, e.g. Adams v. United States ex rel. McCann, 317 U.S. 269, 274-75 (1942); 
cally could not be understood to have thereby waived an appeal; ${ }^{509}$ and that prisoners convicted on the basis of government-tolerated perjury could not be expected to discover that fact in time to make it the basis of a timely appeal. ${ }^{510}$ The result was a spate of Supreme Court remands for de novo habeas corpus review in cases in which lower federal courts, applying pre-existing exhaustion and constitutional doctrine, had denied review altogether. 511 As before, the Court consistently described the range of claims cognizable on habeas corpus as all constitutional claims ${ }^{512}$ - only sometimes with a bow in the direction of the "jurisdiction"-withdrawing effect of such violations $\mathrm{s}^{13}$-and when, instead of remanding, it conducted review itself, it did so de novo on the law but deferentially on the facts. ${ }^{514}$

On the state-prisoner side, the range of available constitutional rights grew as slowly as incorporationism, but all rights that did exist were enforced on habeas corpus, as on appeal, with de novo legal review. 515 Accordingly, when Congress undertook to codify existing habeas corpus practice in the new Judicial Code of 1948, it made all constitutional claims cognizable, adopted no qualifications on the traditional scope of review of legal and factual questions, and made exhaus-

Walker v. Johnston, 312 U.S. 275, 286-87 (1941); Johnson v. Zerbst, 304 U.S. 458, 465, 467 (1938).

509. See, e.g., Waley v. Johnston, 316 U.S. 101, 104-05 (1942).

510. See Sunal v. Large, 332 U.S. at 177-78 (dicta); see also Adams v. United States ex rel. McCann, 317 U.S. at 272-73 (nonexhaustion excused where prisoner could not afford transcript needed to perfect appeal); Bowen v. Johnston, 306 U.S. 19, 26 (1939) ("rule requiring resort to appellate procedure" suspended in order to resolve conflict among courts on important question of federal jurisdiction); Escoe v. Zerbst, 295 U.S. 490, 494 (1935) (excusing requirement that other remedies be exhausted, in challenge to parole revocation, because none existed).

511. See, e.g., United States ex rel. McCann v. Adams, 320 U.S. 220, 222 (1943); Waley v. Johnston, 316 U.S. at 105; Walker v. Johnston, 312 U.S. at 287; Johnson v. Zerbst, 304 U.S. at 469.

512. See, e.g., United States v. Hayman, 342 U.S. 205, 212 (1952); Sunal v. Large, 332 U.S. at 178-79; Waley v. Johnston, 316 U.S. at 105; see also Salinger v. Loisel, 265 U.S. 224, 232-33 (1924) (Sixth Amendment); Baender v. Barnett, 255 U.S. 224, 226 (1921) (Fifth Amendment and Article 1, § 8); Ex parte Hudgings, 249 U.S. 378, 379 (1919) (Fifth Amendment).

513. See, e.g., Bowen v. Johnston, 306 U.S. at 23-24 (citing cases); Johnson v. Zerbst, 304 U.S. at 467-68.

514. See, e.g., Bowen v. Johnston, 306 U.S. at 28 (de novo legal review); Escoe v. Zerbst, 295 U.S. at 429-39 (same); Matter of Gregory, 219 U.S. 210, 214 (1911) (no review of insufficiency of evidence claims); Harlan v. McGourin, 218 U.S. 442, 448, 451-52 (1910) (de novo review of claim that prisoner's sentence violated federal law but no review of insufficiency of evidence claim).

515. See, e.g., Wade v. Mayo, 334 U.S. 672, 677 (1948); Hawk v. Olsen, 326 U.S. 271,276 (1945) ("When . . . error, in relation to the federal question of constitutional violation, creeps into the record, we have the responsibility to review the proceedings."); Ashe v. United States ex rel. Valotta, 270 U.S. 424, 425-26 (1926); supra notes $113-115$ and accompanying text. 
tion of state remedies a matter of timing, not preclusion. ${ }^{516}$

The defining issue for the Court during this period was one that Moore implicitly decided but did not explicitly settle: if direct Supreme Court review on the merits as of right precluded subsequent federal review on habeas corpus, what, then, was the effect of the Court's newly certiorarified direct appeal? As did Moore, some pre-Brown cases assumed or concluded that the Court's denial of certiorari did not supply the statutorily mandated review as of right, which, accordingly, only habeas corpus could afford.517 Other decisions did give the denial of certiorari effect, although, in keeping with the newly established successive-federal-petition principle of Salinger $v$. Loisel, ${ }^{518}$ it was only a partial, and not a fully res judicata, effect. 519

\section{H. The Brown "Revolution": The Impact of Certiorarification Realized}

lt should now be clear that Brown is anticlimax. True, between two majority opinions, the case did nicely catalogue the governing habeas corpus principles. ${ }^{520}$ But those principles already were long established, to anyone with the patience to search them out from among the literally hundreds of individually unimportant cases in which they lay dispersed. The only revolution Brown worked, therefore, was one that seems so obvious today that we can hardly imagine anyone having thought the law different-its holding that a denial of certiorari was not a ruling on the merits. ${ }^{521}$

Brown did serve a critical function. For years following Congress' 1885 warning and the Court's 1886 response in Royall, the Court had largely shut down habeas corpus by giving itself the federal review-asof-right burden the Reconstruction Congress previously had encouraged the Court to share with the lower federal courts on habeas corpus and removal. It took the Court time to come to grips with the fact that the certiorarification of its direct appeal docket made the Royall compromise untenable. Although Frank and especially Moore adumbrated the Court's eventual resolution, only Brown forthrightly adopted it: all prisoners deserve one federal-court appeal as of right of

516. See Act of June 25, 1948, ch. 646, pt. VI, ch. 153, §§ 2241-2255 62 Stat. 869, 964-68 (current version at 28 U.S.C. $\$ \S 2241-2256$ (1988)); H.R. Rep. No. 308, 80th Cong., lst Sess. A177-78 (1947) (1948 codification of habeas corpus provisions not intended substantively to change existing practice); infra notes 528-529 and accompanying text. The 1948 statute did codify Salinger $v$. Loisel's modified res judicata rule on successive habeas corpus petitions. See supra note 506.

517. See, e.g., Wade v. Mayo, 334 U.S. at 677-78; White v. Ragen, 324 U.S. 760, 764-65 (1945); Mooney v. Holohan, 294 U.S. 103, 115 (1935) (dicta); see supra notes 489-491 and accompanying text.

518. 265 U.S. 224 (1924).

519. See supra note 506 .

520. See supra notes $108-158$ and accompanying text.

521. The court's holding is in Justice Frankfurter's opinion. Justice Reed dissented. See supra notes 119,129 and accompanying text. 
their federal constitutional claims, if not on direct review in the Supreme Court, then on habeas corpus in the lower federal courts. As in other appeals, the scope of review was to be de novo on the law, deferential on the facts. In the federal prisoner context, the appeal generally would be a direct appeal to a United States Court of Appeals, unless the prisoner could not reasonably be expected to raise his claims in the immediate wake of trial. In the state-prisoner context, with direct Supreme Court review on the merits as of right having gone the way of the snow leopard-but a few sightings each year-the bulk of the review responsibility would fall to the lower federal courts (and, at times, the Supreme Court) on habeas corpus.

One question remained: Now that the force of its 1885 nudge had run out, would Congress prod the federal courts again?

\section{Congressional Affirmation: The 1966 Amendments}

Congress did no such thing. Although "[i]n 1966, Congress carefully reviewed the habeas corpus statutes and amended their provisions, ... weigh[ing] the interests of the individual prisoner against the sometimes contrary interest of the State,"522 in doing so it only confirmed and, indeed, strengthened the parity between and substitutability of direct and habeas corpus review.

Consider first what Congress, although asked, refused to do. Just as in $1867,1885,5231948,524$ and at least twenty-eight times between 1968 and 1992,525 Congress between 1953 and 1966 repeatedly refused to withdraw the lower federal judiciary from de novo review of some or all state and federal court constitutional determinations in criminal cases. ${ }^{526}$ The emphasis in these proposals on curbing in-

J.).

522. Kuhlmann v. Wilson, 477 U.S. 436, 449 (1986) (plurality opinion of Powell,

523. See supra notes $417-420$ and accompanying text.

524. See, e.g., Report of the Judicial Conference 22-23 (1943) (proposing that state determinations of law and fact be conclusive unless the prisoner could show that state law provided no "adequate remedy" for his constitutional claims); Report of the Judicial Conference 22 (1944) (renewing recommendations of 1943 report); S. 1451, 79th Cong., 1st Sess. (1948) (same); John J. Parker, Limiting the Abuse of Habeas Corpus, 8 F.R.D. 171 (1948).

525. See Biden/Edwards Amicus Brief, supra note 4, at 10-16 (cataloguing 1968-1992 proposals).

526. Bills to curb habeas corpus were introduced at the beginning of all six Congresses between Brown's announcement and the enactment of the 1966 amendments. The most important proposal, which was periodically reintroduced, would have forbidden federal habeas corpus redetermination of legal and factual conclusions made by state courts in proceedings affording a "fair and adequate opportunity" to litigate such questions. The bills and the hearings and debates on them are summarized in Civiletti Amicus Brief, supra note 3, at 15-28; Biden/Edwards Amicus Brief, supra note 4, at 7-8; Bruce W. Ewing, Habeas Corpus Legislation in the United States Congress, 1955-1966 (Jan. 28, 1992) (unpublished manuscript, on file with Columbia Law Review); infra note 527. 
dependent federal review reveals that Brown's endorsement of de novo review, which eluded Justice Thomas in Wright, was clear enough to the writ's legislative opponents from 1953 to 1966 , and since. ${ }^{527}$

Congress instead adopted a set of amendments that, to be sure, addressed the standard of review on habeas corpus, but in a way that thoroughly confirmed the Court's practice before 1963 and cut back only on its short-lived innovations of the mid-1960s that anomalously accorded broader review to habeas corpus petitioners than the Court itself could provide on direct review.

The 1948 codification of the 1867 act, which the 1966 amendments revised, made the habeas corpus cognizability of constitutional claims and the default de novo standard of review repetitively mandatory. The mandate the statute's plain language imposed was precisely the one under which both Justices Reed and Frankfurter explicitly operated in Brown (somewhat to the discomfort of the latter): ${ }^{528}$ District courts "shall entertain" applications "on the ground that [the applicant] is in custody in violation of the Constitution or laws or treaties of the United States" and "shall forthwith award the writ ... unless ... the applicant . . . is not entitled thereto." 529 The 1966 amendments left all the mandatory language intact. Today, as in 1948 (and in 1867 and 1874), the statute's default position is that a prisoner in custody in violation of the Constitution "shall" have the writ.

Onto this default rule, however, the 1966 amendments engrafted three standard of review qualifications. First, Congress provided that, with one exception, a prisoner whose unconstitutional-incarceration claims the Supreme Court previously had rejected on the merits on appeal or certiorari shall not have the writ; in the rare instances in which it is granted, review by the Supreme Court on direct appeal is both preferred and, once it occurs, res judicata.$^{530}$

527. The legislative history is filled with statements that proposals to curb habeas corpus were inspired by Brown, and particularly by its confirmation that "a defendant [who] has been convicted in a State court, [had the] conviction affirmed ... [in] an intermediary court in the State ... and affirmed by the Supreme Court of the United States or certiorari denied, . . . still ... has the right under the present . . . law to go into a Federal trial court and have the whole thing reviewed." Proposed Amendments to $\S 2254$ of Tit. 28 of the U.S. Code in Reference to Applications for Writs of Habeas Corpus by Persons in Custody Pursuant to the Judgment of a State Court: Hearings before Subcomm. No. 3 of the House Judiciary Comm., 84th Cong., 1st Sess, 12 (1955) (testimony of Chief Justice Weygandt of the Ohio Supreme Court); accord id. at 3-4, 10 (testimony of Chief Judge John Parker); 102 Cong. Rec. 936 (1955) (statement of Rep. Celler); id. at 939 (statement of Rep. Quigley); Biden/Edwards Amicus Brief, supra note 4 , at 7-16 (collecting similar statements from 1950s to 1990s); supra note 159 .

528. See Brown v. Allen, 344 U.S. 443, 460-61 (1953) (opinion of Reed, J.) (citing 28 U.S.C. § 2243); id. at 505 (opinion of Frankfurter, J.) (citing same); supra notes 113 and $139-140$ and accompanying text.

529. 28 U.S.C. $\S \S 2254(\mathrm{a}), 2241$ (c)(3), 2243 (1988).

530. See 28 U.S.C. $\$ 2244$ (c) (1988). The one exception occurs when "the applicant ... shall plead and the [habeas corpus] court shall find the existence of a 
Second, Congress provided that, with one exception, a prisoner whose claims to be in state custody in violation of the Constitution a federal habeas corpus court had previously heard and denied on the merits "need not"-but, in the discretion of the court, may-have the writ. ${ }^{531}$ Thus, although not res judicata, prior review by another federal court on habeas corpus is generally a sufficient reason for a court hearing a second or successive petition to deny relief.

Third, Congress provided that, with eight exceptions relating to the "full[ness] and fair[ness]" of the prior proceeding, a prisoner whose claims to be in state custody in violation of the Constitution a state court had previously heard and denied on the basis of a determinative finding of historical fact must be denied the writ except on a showing "by convincing evidence" that the finding is erroneous. ${ }^{532}$ In other words, a prior "full and fair" determination of the facts by a state court is due the same deference the clearly erroneous rule affords factfindings in other appellate settings.

If these three qualifications sound familiar, that is no surprise. The first qualification is simply the Royall-Frederich-Eno rule codified, "leaving" prisoners to their appellate remedies in the United States Supreme Court when available as of right. ${ }^{533}$ The second qualification is simply the Court's post-Moore successive petition rule announced in Salinger $v$. Loisel. ${ }^{534}$ And the third qualification is simply the 200-yearold rule, applied, for example, in Frank, requiring deferential habeas corpus review of issues of "pure fact."535 Taken as a whole, the three qualifications simply reprise the catalogue of standards of review that Justices Reed and Frankfurter, each in his own way, included in their respective summaries in Brown of pre-existing habeas corpus practice. ${ }^{536}$

Once engrafted onto the 1948 recodification of the 1874 codification of the 1867 statute, the 1966 amendments say simply this: A prisoner in "custody in violation of the Constitution" "shall" have the writ (1) unless the Supreme Court previously said the prisoner was not in custody in violation of the Constitution, in which case the Court's deci-

material and controlling fact which did not appear in the record of the proceeding in the Supreme Court and the court shall further find that the applicant for the writ of habeas corpus could not have caused such fact to appear in such record by the exercise of reasonable diligence." Id.

531. See 28 U.S.C. \$2244(b) (1988). The one exception arises when "the application alleges and is predicated on a factual or other ground not adjudicated on the hearing of the earlier application for the writ, and . . . the court, justice, or judge is satisfied that the applicant has not on the earlier application deliberately withheld the newly asserted ground or otherwise abused the writ." Id.

532. 28 U.S.C. $§ 2254$ (d) (1988).

533. See supra notes $425-439$ and accompanying text.

534. 265 U.S. 224 (1924). See supra note 506.

535. See supra notes $334,366,409,412,450,498,514$ and accompanying text.

536. See supra notes $121-124,142-145$ and accompanying text. 
sion is conclusive on "all issues of fact or law"; or (2) unless another federal court in a prior habeas corpus proceeding said the same thing, in which case the prior court's decision is persuasive on the facts and law, though not quite conclusive; or (3) unless a state court fully and fairly found facts that are inconsistent with unconstitutional incarceration, in which case, the state court's decision is dispositive on the facts as long as it is not clearly erroneous.

But, it might be said, the statute does not specify how a court is to determine whether a violation exists; the words "de novo review" are nowhere to be found. More particularly, it might be asked, if Congress in 1966 set about codifying the prior law that it approved, why did it not explicitly codify the de novo review rule? There are three answers to this question.

First, as the Court recently noted in Tamayo-Reyes $v$. Keeney, ${ }^{537}$ the 1966 amendments did not quite codify prior law. More accurately, they restored prior law against some of the controversial changes the Court made in its famous 1963 trilogy of habeas corpus cases ${ }^{538}$ - changes that in each instance (1) were resisted by Justice Harlan and others in forceful dissenting opinions; ${ }^{539}$ (2) spoiled direct-appeal/habeascorpus parity by giving more review to habeas corpus petitioners than they would have received had the Court granted certiorari in their cases on direct review; (3) have been identified for that reason by Professor Wechsler and others as among the Court's most egregiously wrongheaded innovations in recent memory; ${ }^{540}$ and (4) have since been eradicated by the Court, to the extent that they were not previously eradicated by Congress.

The 1966 Congress' curious need to codify rules already established in 1886 thus derived from the intervening 1963 decisions. The amendments' limits on post-Supreme Court review and on successive lower federal court review responded directly to Sanders $v$. United States, ${ }^{541}$ which risked undermining the Royall-Frederich-Eno and

537. 112 S. Ct. 1715,1717 n.2 (1992).

538. Sanders v. United States, 373 U.S. 1 (1963); Fay v. Noia, 372 U.S. 391 (1963), questioned in Wainwright v. Sykes, 433 U.S. 72, 87-88 (1977), and overruled by Coleman v. Thompson, 111 S. Ct. 2546, 2565 (1991); Townsend v. Sain, 372 U.S. 293 (1963); accord H.R. Rep. No. 1892, 89th Cong., 2d Sess. 6 (1966) (describing the Supreme Court's announcement of the 1963 decisions as prompting a demand for legislation "with respect to applications for habeas corpus by persons confined under judgments of State courts"); 110 Cong. Rec. 14680 (1964) (statement of Rep. Wyman) (opposing the proposal that ultimately became the 1966 amendments because it was "legislation to undo decisions of the Supreme Court, particularly Fay v. Noia").

539. See Sanders v. United States, 373 U.S. at 23-32 (Harlan, J., dissenting); Fay v. Noia, 372 U.S. at 448-76 (Harlan, J., dissenting); Townsend v. Sain, 372 U.S. at 325-34 (Stewart, J., dissenting, joined by Harlan, J.).

540. See Wechsler, supra note 264, at 178; see also Fay v. Noia, 372 U.S. at 448 (referring to decision as "one of the most disquieting that the Court has rendered") (Harlan, J., dissenting).

541. 373 U.S. 1 (1963). 
Salinger rules by inviting (without defining) such successive federal review as "the ends of justice demand." The amendments' limits on redetermination of state-court fact finding responded just as directly to the liberalization in Townsend $v$. Sain ${ }^{542}$ of the rule of Brown and prior cases that federal habeas corpus courts generally should defer to state court factfindings. ${ }^{543}$

One thing the 1963 cases did not do was change prior law on the standard of review of legal and mixed legal and factual questions. On that question, two of the 1963 decisions reiterated prior law.544 Moreover, Justice Harlan and the other dissenters concurred in this restatement ${ }^{545}$ - which explicitly maintained parity between habeas corpus and the Court's direct review ${ }^{546}$-and the Federal Courts titans such as Hart and Wechsler saw nothing objectionable in the restatement. ${ }^{547}$

The juxtaposition of Congress' action on both successive federal review and review of state court factual determinations with its inaction on review of state court legal and mixed determinations is thus double proof of Congress' intention to endorse the existing de novo review rule, which (1) the Court did not find it necessary to change in the process of changing other aspects of existing law, and (2) which preserved the longstanding prior law whose restoration was the principal product of the amendments Congress did make. Congress' silence thus is its consent to the pre-existing de novo review rule, not only because "[t]he normal rule of statutory construction is that if Congress intends for legislation to change the interpretation of a judicially created concept, it makes that intent specific," 548 but more importantly because Congress' manifest goal of maintaining the longstanding rule of parity between habeas corpus and direct review could only be achieved by preserving de novo review.

Were this a statutory interpretation examination, and not an article, the simple question presented might read as follows:

A statute says that 'a [federal] district court shall entertain an application for a writ of habeas corpus in behalf of a person ... in custody in violation of the Constitution,' and that the

542. 372 U.S. 293 (1963).

543. On Townsend's liberalization of prior law, see Keeney v. Tamayo-Reyes, $112 \mathrm{~S}$. Ct. 1715, 1717-18 n.2 (1992); Smith v. Yeager, 393 U.S. 122, 125 (1968) (per curiam).

544. See Townsend v. Sain, 372 U.S. at 318, 326 n.l ("[T] he district judge . . . may not defer to [the state court's] findings of law ... [and] must apply the applicable federal law to the state court fact findings independently.").

545. See Fay v. Noia, 372 U.S. 391 460-68 (Harlan, J., dissenting) (1963), questioned in Wainwright v. Sykes, 433 U.S. 72, 87-88 (1977), and overruled by Coleman v. Thompson, 111 S. Ct. 2546, 2565 (1991); Townsend v. Sain, 372 U.S. at 325-27 (Stewart, J., dissenting); supra notes $167-168$ and accompanying text.

546. See Townsend v. Sain, 372 U.S. at 313, 326 n.1.

547. See supra note 159 .

548. Midlantic Nat'l Bank v. New Jersey Dep't of Envtl. Protection, 474 U.S. 494, $501 \cdot(1986)$. 
federal district court 'shall . . . award the writ' to such a person. ${ }^{549}$ By way of qualification of that statement, the statute says only that the 'State court' shall control the 'determination ... of . . factual issue[s]' decisive of the existence of a violation of the Constitution. ${ }^{550}$ Whose decision controls the determination of legal issues decisive of the existence of a "violation of the Constitution"-(A) the federal district court's decision; or (B) the state court's decision?

Am 1 wrong that a "(B)" answer would merit a failing grade?

Let me use yet another question to introduce my next point. If, by omitting any explicit standard of review, the drafters of the statute did not intend de novo review of decisive constitutional legal questions, then what other standard of review did they intend? Assumedly, the answer to this question is that, by not specifying de novo review, the drafters intended to adopt some other standard of review of legal questions that was accepted in the broader legal culture at the time. But, in 1789, 1867,1948 , or 1966 , the only accepted standards governing one court's review of another court's resolution of questions denominated as legal (including, after 1912, "mixed" questions) were de novo review and no review (e.g., because a prior determination was res judicata). ${ }^{551}$ Clearly, Congress could not have intended the mandate that "a district court shall entertain an application for a writ of habeas corpus in behalf of a person . . . in custody in violation of the Constitution" 552 to mean that the district court shall not entertain that application because the state judgment is dispositive of (i.e., is res judicata as to) the existence of custody in violation of the Constitution. The answer, then, to the question "If not de novo review, then what?" must be "There is no answer; Congress intended by its silence to adopt a standard of review that had never before been accepted in the sphere of courts reviewing courts."

Finally, the history of the 1966 legislation reveals its intent to maintain the pre-existing de novo review rule. To begin with, state-

549. 28 U.S.C. $\S \S 2254$ (a), 2241 (c)(3), 2243 (1988).

550. 28 U.S.C. $\& 2254$ (d) (emphasis added) (1988).

551. Cf. Monaghan, supra note 12 , at 229-39, 247-54 (assuming that courts must choose between de novo and no review). True, the notion of deferential judicial review of an administrative agency's interpretations of its organic laws had arisen by the 1940s, although the extent of its acceptance prior to Chevron U.S.A. Inc. v. Natural Resource Defense Council, Inc., 467 U.S. 837 (1984), is unclear. See Walter Gellhorn et al., Administrative Law 379-404 (7th ed. 1987). But no similar notion had arisen, much less been accepted, for courts reviewing courts. Moreover, the reasons for a court's deferring to an administrative agency do not apply in the current context. Compare Chevron U.S.A. Inc. v. Natural Resource Defense Council, Inc., 467 U.S. at 843, 865-66 (judicial deference is warranted by Congress' implied intent, in adopting the agency's organic law, to give the agency superior interpretive authority, and by the agency's superior technical and political expertise) with Martin v. Hunter's Lessee, 14 U.S. (1 Wheat.) 304, 351 (1816) (Constitution gives state courts no immunity from federal court review of their determinations of federal law and makes federal court interpretations of federal law superior to state court interpretations).

552. 28 U.S.C. $§ 2254$ (a) (1988). 
ments about the remedial ${ }^{553}$ and deterrent ${ }^{554}$ purposes of the writ simply will not jibe with a rule forbidding district courts to remedy constitutional violations and validating "reasonable" state court decisions that make and affirm constitutional violations. Second, the legislators and the sources to whom they were listening most closelyprincipally, the Judicial Conference, the Eisenhower Justice Department, and Chief Justice Warren on behalf of the federal judiciary-frequently described habeas corpus and Supreme Court direct review on the merits as substitutes. ${ }^{555}$ From this understanding, it is, of course, no leap at all to infer that the review available in the substitute forums was to be the same.

But nothing needs to be inferred. A Judicial Conference Committee drafted the amendments Congress passed in 1966 in order to block an anticipated proposal by the state chief justices and attorneys general to "make the finding of fact of a State court conclusive in a proceeding in habeas corpus." 556 What the Judicial Conference most strongly opposed in the state officials' proposal was the possibility that it would require deference to state court determinations of mixed questions of fact and law. To that extent, the Judicial Conference concluded, the proposal "would be wholly incompatible with the duty of Federal courts to determine Federal constitutional questions." 557 That duty, the committee explained, quoting Brown, meant affording state court legal determinations " 'the weight that federal practice gives to the conclusion of a court of last resort in another jurisdiction on Federal constitutional issues," "that is, "'respectful attention to [its] reasoning and conclusion," " but not deference. ${ }^{558}$

Even more to the point, the committee relied on three classic direct appeal decisions in which the Supreme Court extended its "duty to determine constitutional questions" " to mixed questions of law and fact. ${ }^{559}$ Lest the point be missed, the committee concluded by quoting a passage from Townsend $v$. Sain ${ }^{560}$ describing the Court's de novo review obligation on direct appeal in mixed question cases and saying that " "[t]he duty of the Federal district court on habeas is no less exacting." "561

553. See, e.g., H.R. Rep. No. 1892, 89th Cong., 2d Sess. 4, 9 (1966).

554. See, e.g., S. Rep. No. 1797, 89th Cong., 2d Sess. 3 (1966).

555. See, e.g., 1963 Report of the Judicial Conference Committee on Habeas Corpus, 33 F.R.D. 367, 371 (1963) (views of Judicial Conference and Chief Justice Warren); Justice Department Memorandum-H.R. 8361: Federal Habeas Corpus for State Prisoners, reprinted in 104 Cong. Rec. 19432-44 (1958).

556. H.R. Rep. No. 1384, 88th Cong., 2d Sess. 1-3, 6, 22-23 (1964) (appending and adopting the analysis of the Judicial Conference report).

557. Id. at 23 (emphasis added).

558. Id. at 24 (quoting Pennekamp v. Florida, 328 U.S. 331, 335 (1946)).

559. Id. (quoting Blackburn v. Alabama, 361 U.S. 199, 205 (1960)).

560. 372 U.S. 293 (1963).

561. H.R. Rep. 1384, supra note 556, at 24 (quoting id. at 316). 
Perhaps most to the point, however, is a bottom-line exchange between two members of Congress and the Judicial Conference's spokesperson, Judge Orie Phillips, about the Judicial Conference proposal then being developed. When asked in congressional hearings whether the proposal that ultimately became the 1966 amendments "would result in curbing the right to the great writ on a meritorious case" or, if it would not "abrogate it[,] . . . would actually disturb the right," Judge Phillips, answered, "I do not think that [the bill] changes present practice."562

In short, Congress seems to have known exactly what it was doing in 1966. As the House Judiciary Committee concluded in approving the 1966 amendments, "[t]he substitute [bill] . . . creates reasonable presumptions and fixes the party on whom the burden of proof, as to certain factual issues, shall rest in such proceedings, without impairment of any of the substantive rights of the applicant."563

All interpretive roads lead to the same conclusion: Congress knew that federal habeas corpus courts were reviewing pure and mixed legal questions de novo and aimed to preserve that standard of review. Hence, when the drafters of the 1966 amendments left intact the 1948 (and 1867) provisions requiring that "a district court shall entertain an application for a writ of habeas corpus in behalf of a person ... in custody in violation of the Constitution,"564 they meant what they said: that it was the "district court," and not the state court, that had the duty to determine the constitutional question.

\section{J. Summary}

Since 1789 , Congress has provided federal appellate review as of right of all fundamental federal questions-and since Reconstruction, constitutional questions-raised by the government's or a state's decision to incarcerate an individual. When meaningfully available, federal appellate review as of right in the Supreme Court on writ of error has been the preferred mode of federal review, at least for state prisoners. But when Supreme Court review as of right on writ of error has been unavailable or has provided insufficient protection of federal law

562. Habeas Corpus: Hearings before Subcomm. No. 3 of the House Comm. on the Judiciary, 86th Cong., 1st Sess. 18 (1959) (exchange between Reps. Willis and Libonati and Judge Orie L. Phillips). Ohio Chief Justice Weygandt, a strong proponent of legislation to make state court legal and factual determinations decisive in federal habeas corpus proceedings, similarly described the bill about which Judge Phillips was testifying: "The present . . . bill accomplishes none of the objectives sought by the Conference of Chief Justices. In fact, it does the opposite in that it would afford permanent statutory approval of the misuse of the writ resulting from the decisions of the Federal Supreme Court." 105 Cong. Rec. 14635-36 (1959) (statement of Rep. Feighan, appending letter of Chief Justice Carl W. Weygandt) (emphasis added).

563. H.R. Rep. No. 1892, 89th Cong., 2d Sess. 3 (1966) (emphasis added); accord S. Rep. No. 1797, 89th Cong., 2d Sess. 3, 6 (1966).

564. 28 U.S.C. § 2254(a) (1988). 
against state court resistance, Congress has authorized the federal courts to employ habeas corpus, along with removal and (in the federal-prisoner context) appeals as of right to the United States Courts of Appeals, as surrogates for the Court's direct review as of right. ${ }^{565}$

On the state prisoner side, Supreme Court review on writ of error sufficed for all prisoners from 1789 until 1815 and 1833. At these latter points, state court threats to nullify federal duties and tariffs by prosecuting their collectors led Congress to give federal employees removal and habeas corpus rights, lest hostile state proceedings indeed nullify federal law before an opportunity for federal writ-of-error review became available. In 1867 , Southern courts' threats to nullify newly given federal rights led the Reconstruction Congress to extend the federal courts' removal and habeas corpus authorizations to intervene in, rather than await the end of, state court proceedings whenever necessary to protect any prisoner's federal rights.

With Reconstruction's close and a strong signal from Congress in 1885 , the Court restored the preference for its own review as of rightin the habeas corpus context, by requiring state prisoners to exhaust the Court's writ of error remedy when meaningfully available. The moment Supreme Court review as of right was not meaningfully available, however, following the Court's unofficial, then Congress' official, certiorarification of the Court's appellate docket, the Court reinvigorated habeas corpus review. This reinvigoration culminated in Brown's 1953 acknowledgement and Congress' 1966 confirmation that the Court's certiorari denial did not supply the requisite review on the merits and that habeas corpus review-commensurate in substance and scope with the Court's unavailable direct review-would have to fill the breach.

On the federal prisoner side, the story is similar, if simpler. In lieu of federal appellate rights, Congress in 1789 afforded habeas corpus review, which for a century the Court consistently used to remedy violations of fundamental (after the Civil War, constitutional) rights in criminal trials. The onset of federal appellate rights in 1891 (first on writ of error in the Court itself; later, in the newly created courts of appeal), and the Court's immediate conclusion that those rights, when meaningfully available, superseded the writ, placed federal-prisoner habeas corpus on ice until the Criminal Procedure Revolution of the 1930s and 1940 s expanded the number of situations in which appellate remedies

565. Treating removal as a form of writ of error is, e.g., McKee v. Rains, 77 U.S. (10 Wall.) 22, 25-26 (1869); Martin v. Hunter's Lessee, 14 U.S. (1 Wheat.) 304, 319-20, 349-50 (1816); treating the writ of error as a form of removal is, e.g., Dower v. Richards, 151 U.S. 658, 665 (1894); treating habeas corpus as "in the nature of a writ of error" is, e.g., Ex parte Watkins, 28 U.S. (3 Pet.) 193, 202 (1830); treating habeas corpus as a form of removal is, e.g., Ex parte Bollman, 8 U.S. (4 Cranch) 75, 97-98 (1807); treating removal and habeas corpus as substitutes is, e.g., Hart \& Wechsler, $2 \mathrm{~d}$ ed., supra note 38 , at 423; treating removal and writs of error as substitutes is, e.g., The Mayor v. Cooper, 73 U.S. (6 Wall.) 247, 253-54 (1867); treating habeas corpus and writs of error as substitutes is, e.g., In re Chapman, 156 U.S. 211, 216-18 (1895). 
were understood to be inadequate, and surrogate review in the lower courts on habeas corpus was accordingly understood to be necessary.

Professors Bator and Peller, then, were both right, and both wrong. Bator was right to tie changes in the availability of habeas corpus review and relief to changes in the level of attention federal habeas corpus courts paid to determinations of prior courts, but was wrong (1) in describing federal question review on habeas corpus as limited to less than all fundamental questions, (2) in perceiving the exhaustion doctrine as making state court, rather than prior federal court, review preclusive, (3) in using the res judicata analogy of a prior lawsuit's effect on a subsequent one, when the analogy of a subsequent court's appellate review of another was more robustly explanatory, and (4) overlooking the difference between federal court deference to state court determinations of fact (which, as in any appeal, was routine) and federal court deference to state court judgments (which, as on appeal, did not occur). Bator thus got habeas corpus wrong because he forgot his federal jurisdiction-and thus lost sight of the analogy to writ of error and removal review that Justice Gray so elegantly had laid out in Whitten. 566

Likewise, Professor Peller correctly discerned Bator's error in underestimating the range of cognizable claims, but erred in ignoring the large number of denials of habeas corpus review that are not explained by limits on the reach of the Constitution. Peller thus failed to tie those denials to the preference for direct Supreme Court review as of right, when available, and to limits on the Court's direct review (and thus on its surrogate, habeas corpus review) of questions of fact. By remaining agnostic on whether res judicata or appellate analogies best explain habeas corpus, Peller's thesis is incomplete.

What, though, of Professor Bator's conundrum: Except as an incident to the application of res judicata, what good is an exhaustion-ofstate-remedies doctrine?

The reason a nonpreclusive exhaustion doctrine seemed inexplicable to Professor Bator is that he mistook his metaphor for reality. On a "separate civil action" view of habeas corpus, the denial of relief on a claim in a prior action surely should have res judicata effect in a later action. But switch analogies, and place the exhaustion doctrine in an appellate context. Indeed, the exhaustion doctrine need not be analogized to an appellate context, for it literally creates that context by forbidding a litigant to seek review in an appellate court until she first has raised the claim in a lower one-thus giving the reviewing court something to review. And indeed, throughout most of the nineteenth century, the Supreme Court was careful to construe habeas corpus jurisdiction as consisting of one court's "appellate" review of 
another. ${ }^{567}$

Understood this way, the exhaustion doctrine serves three very real functions. First, it forces litigants to seek satisfaction in the more numerous prior courts, leaving only a smaller number of claims for appeal to the smaller number of appellate courts. Second, it defines the issues, so that by the time the case reaches the appellate stage, a pristine set of legal issues can be extracted and presented for efficient appellate review. Third, it resolves factual questions, which, from the beginning of habeas corpus review, have been singled out as singularly unworthy of habeas corpus relitigation on the mundane grounds that have always made trial courts superior when it came to the facts. ${ }^{568}$ Thus, as Justice Gray was very careful to say in Whitten, habeas corpus, like direct appeals, is a "method[] . . . for bringing before the courts of the United States proceedings [that were] begun in the courts of the States," but that end in the federal courts. ${ }^{569}$

\section{Conclusion: The Wright Stuff Versus The Right Stuff}

At least two cases this Term present anew the question the Court presented itself in Wright, then dodged. ${ }^{570}$ It seems inevitable that in those cases or in later ones, the opening skirmish in Wright will escalate into all-out Armageddon over the future of de novo habeas corpus review-in essence, the future of habeas corpus review itself. The question this Article poses is whether Justice O'Connor's analysisintellectually victorious in Wright - has the right stuff to win the coming war over habeas corpus.

Justice O'Connor's position seems credible on its face. The habeas corpus remedy she describes has the virtues of at least forty years of precedential backing and of parity with the Court's own review on direct appeal.

Moreover, Justice O'Connor can use the same analysis to explain the Court's entire habeas corpus jurisprudence over the past fifteen years-which in large measure has been her own, with contributions from Justice Kennedy. A simple and inclusive explanation of that jurisprudence is that it finishes the work-that the Court made for itself in its 1963 trilogy of habeas corpus cases and that Congress began in its 1966 habeas corpus amendments ${ }^{571}$ - of restoring habeas corpus to its longstanding parity with direct review.

Via the exhaustion doctrine, the Court recently has assured that habeas corpus petitioners, like direct appellants, cannot seek the re-

567. See supra note 349 and accompanying text.

568. See supra note 48 and accompanying text; see also 1 Liebman, supra note 24 , $\$ 5.2$ (more detailed presentation of this argument).

569. Whitten v. Tomlinson, 160 U.S. 231, 238 (1895) (emphasis added); see 1-2 Liebman, supra note $24, \S \S 5.2,35.16$.

570. See supra note 5 .

571. See supra notes $537-547$ and accompanying text. 
viewing court's consideration before seeking the prior court's judgment. Most importantly, Justice O'Connor's 1982 "total exhaustion" decision in Rose v. Lundy ${ }^{572}$ assured that habeas corpus petitioners, like direct appellants, have only a single unified review of all their claims, not many piecemeal reviews following claim-by-claim exhaustion in the state courts. ${ }^{573}$ Rose's "total exhaustion" rule having required habeas corpus petitioners, like direct appellants, to aggregate all their claims in proceedings in the prior courts before bringing any of their claims to the federal courts, Justice Kennedy's successive-petition decision in McCleskey $v$. Zant, ${ }^{574}$ then required habeas corpus petitioners, like direct appellants, to aggregate all their now exhausted claims in one federal review.

The Court's procedural-default cases-Justice O'Connor's decisions in Engle v. Isaac, ${ }^{575}$ Murray v. Carrier, ${ }^{576}$ and Smith v. Murray, ${ }^{577}$ and, most importantly, her 1991 decision in Coleman v. Thompson 578 then used a "cause and prejudice" test, which provides a nearly perfect proxy for the "adequate and independent state grounds" doctrine on direct appeal, ${ }^{579}$ to restore the direct appeal/habeas corpus parity that Fay v. Noia abolished in 1963.580

Finally, Justice O'Connor's nonretroactivity decision in Teague $v$. Lane ${ }^{581}$ and her application of the Teague doctrine in later cases ${ }^{582} \mathrm{de}-$ stroyed the last existing vestige of the mid-1960s assault on direct appeal/habeas corpus parity. Under Linkletter $v$. Walker ${ }^{583}$ and other 1960s cases, the Court had held, once again over Justice Harlan's vehement dissent, ${ }^{584}$ that federal habeas corpus petitioners frequently could take advantage of newly created legal rights that did not exist at the time of their direct appeal proceedings. Teague's nonretroactivity doctrine restores parity by ensuring that the sum total of the law that the

572. 455 U.S. 509 (1982).

573. See id. at 520 .

574. 111 S. Ct. 1454 (1991).

575. 456 U.S. 107 (1982).

576. 477 U.S. 478 (1986).

577. 477 U.S. 527 (1986).

578. 111 S. Ct. 2546 (1991).

579. See Hart, supra note 108, at 118-19 (proposing just this solution 30 years before Court adopted it); supra notes 21,37 and accompanying text.

580. Fay v. Noia, 372 U.S. 391, 429-34, 438-39 (1963) (allowing habeas corpus courts to ignore adequate and independent state grounds for state court's determination except those premised on the prisoner's deliberate waiver of federal rights), questioned in Wainwright v. Sykes, 433 U.S. 72, 87-88 (1977), and overruled by Coleman v. Thompson, 111 S. Ct. 2546, 2565 (1991); see supra note 540 and accompanying text.

581. 489 U.S. 288 (1989).

582. Stringer v. Black, 112 S. Ct. 1130 (1992) (opinion for the Court of Kennedy, J.); Saffle v. Parks, 494 U.S. 484 (1990) (opinion for the Court of Kennedy, J.). See Sawyer v. Smith, 497 U.S. 277 (1990); Penry v. Lynaugh, 492 U.S. 302 (1989).

583. 381 U.S. 618 (1965).

584. See, e.g., Desist v. United States, 394 U.S. 244, 256-57 (1969) (Harlan, J., dissenting). 
prisoner can draw upon in seeking release on habeas corpus is the same as would bave been available on direct appeal in the Supreme Court. ${ }^{585}$

Simply recognizing that the scope and nature of habeas corpus review almost exactly parallel, and substitute for, the Court's own review on direct appeal may satisfy some that federal-question review in criminal cases should remain as it is. For otbers the system's existence for forty years, wbatever its rationale or logic, also may be enough. Justice Kennedy concluded in Wright, for example, that the existence of this system even since 1985 was enough for him. ${ }^{586}$ For still others, however, including perhaps the two Justices who were silent in Wright, more in the way of explanation may be necessary. ${ }^{587}$ Indeed, one (in my view anomalous) facet of Justice O'Connor's habeas corpus jurisprudence is itself an obstacle to acceptance of the existing system's rationality, namely, her view, in Keeney v. Tamayo-Reyes, 588 that habeas corpus is not an appeal, but ratber is an original civil action.

This Article has tried to reveal the fallacy in this one, anomalous and seemingly minor, aspect of Justice O'Connor's habeas corpus jurisprudence. The fallacy appears not only from the "original civil action" theory's contradiction of everytbing the Court and especially Justice O'Connor recently have accomplished in habeas corpus cases. Even more vividly, the fallacy appears from the "original action" theory's contradiction of 204 years of congressional and judicial action in regard not only to habeas corpus but to all federal court review of federal questions. Since 1789, Congress bas entitled federal and state prisoners incarcerated in violation of any fundamental legal (typically, any constitutional) principle to one meaningful federal court review as of right. The model for that review, and its preferred "mode" when available, has been direct review on the merits as of right in the Supreme Court on writ of error or appeal. When direct federal appellate review has not been meaningfully available, however, habeas corpus has consistently filled the breacb. Filling the breach, however, has meant filling it all-providing the same review that the Court itself would have provided on direct review had it been able to do so.

One question remains, of course. Granted that habeas corpus is recognizable as a substitute for limited direct Supreme Court review of nationally important issues for which the Constitution permits federal question jurisdiction. Granted that habeas corpus has functioned tbat way since 1789 . But why should it function that way? I have tried, willy nilly, to provide some answers to this question, as have others. ${ }^{589} \mathrm{But}$,

585. See supra notes $42-43$ and accompanying text.

586. See Wright v. West, 112 S. Ct. 2482, 2498-2500 (1992) (Kennedy, J., concurring in the judgment).

587. See id. at 2493 (White, J., concurring in the judgment); id. at 2500 (Souter, J., concurring in the judgment).

588. 112 S. Ct. 1715, 1722-25 (1992) (O’Connor, J., dissenting).

589. The classic explanation of the need for federal court review of controversial 
once the appellate understanding of habeas corpus-so long obscured by Professor Bator's flawed tour de force-emerges from the history, so does the final answer to this question-the one Justice Story gave in Martin v. Hunter's Lessee, ${ }^{590}$ when presented with precisely the same question directed not at habeas corpus review, but at its model and mentor, writ of error review of federal questions as of right:

It is further argued, that no great public mischief can result from a construction which shall limit the appellate power of the United States to cases in their own Courts . . . because State judges are bound by an oath to support the constitution of the United States, and must be presumed to be men of learning and integrity .... [A]dmitting that the judges of the State Courts are, and always will be, of as much learning, integrity, and wisdom, as those of the courts of the United States, (which we very cheerfully admit,) it does not aid the argument. It is manifest that the constitution has proceeded upon a theory of its own .... The constitution has presumed ... that State attachments, State prejudices, State jealousies, and State interests, might sometimes obstruct, or control, or be supposed to obstruct or control, the regular administration of justice. ... In respect to ... cases arising under the constitution, laws, and treaties of the United States ... , reasons of a higher and more extensive nature, touching the safety, peace, and sovereiguty of the nation, might well justify a grant of [final, federal] . . . jurisdiction. . $^{51}$

Federal law is supreme, as is federal adjudication of that law when mandated by Congress. Throughout the nation's history, moreover, Congress has mandated final federal adjudication of important federal law whenever life or liberty has depended on the outcome. By preference, this adjudication as of right has been the Supreme Court's on direct appeal. By necessity, however, it also has been the lower federal court's on habeas corpus. Nothing in this system of personal rights and judicial responsibilities seems strange to me. But even were the system strange, it nonetheless is the one towards which "the Constitution has proceeded upon a theory of its own."

questions of federal law is Burt Neuborne, The Myth of Parity, 90 Harv. L. Rev. 1105 (1977). See also supra notes 40-41, 370-372, 388-389, 418, 553-554.

590. 14 U.S. (1 Wheat.) 304,349 (1816).

591. Id. at 346-47, 349; accord The Mayor v. Cooper, 73 U.S. (6 Wall.) 247, 253 (1867) (same justification for federal-question removal jurisdiction). 